UNIVERSIDADE DE SÃO PAULO

FACULDADE DE FILOSOFIA, LETRAS E CIÊNCIAS HUMANAS

DEPARTAMENTO DE LETRAS MODERNAS

\author{
GABRIELE FRANCO
}

O cruzamento de vozes narrativas em La caída de Madrid, de Rafael Chirbes 


\section{GABRIELE FRANCO}

O cruzamento de vozes narrativas em La caída de Madrid, de Rafael Chirbes

Dissertação apresentada ao programa de Pósgraduação em Língua Espanhola e Literaturas Espanhola e Hispano-Americana do Departamento de Letras Modernas da Faculdade de Filosofia, Letras e Ciências Humanas da Universidade de São Paulo, para obtenção do título de Mestre em Letras.

Orientadora: Prof ${ }^{a}$. Dra. Valeria De Marco

São Paulo 
Autorizo a reprodução e divulgação total ou parcial deste trabalho, por qualquer meio convencional ou eletrônico, para fins de estudo e pesquisa, desde que citada a fonte. 
FRANCO, Gabriele.

O cruzamento de vozes narrativas em La caída de Madrid, de Rafael Chirbes

Dissertação apresentada ao programa de Pósgraduação em Língua Espanhola e Literaturas Espanhola e Hispano-Americana do Departamento de Letras Modernas da Faculdade de Filosofia, Letras e Ciências Humanas da Universidade de São Paulo, para obtenção do título de Mestre em Letras.

Orientadora: Profa. Dra. Valeria De Marco

Aprovado em:

Banca Examinadora:

Prof. Dr. Instituição:

Julgamento: Assinatura:

Prof. Dr. Instituição:

Julgamento: Assinatura:

Prof. Dr. Instituição:

Julgamento: Assinatura:

Prof. Dr. Instituição:

Julgamento: Assinatura: 
À memória de meu avô, Francisco Garcia Parra, por me acompanhar desde as primeiras letras. 


\section{AGRADECIMENTOS}

À Profa. Dra. Valeria De Marco pela oportunidade e orientação.

Às professoras Margareth dos Santos e Elisa Amorim pelas recomendações de leitura e orientações durante o exame de qualificação, as quais foram fundamentais para o desenvolvimento da dissertação.

Aos funcionários da Universidade de São Paulo.

À minha família, pelo apoio e amor incondicional.

À família Okada, em especial, Massako e Cecília, por acreditarem em mim.

À tia Marsinha, tio Gilberto e Henrique por me receberem calorosamente.

A Álvaro Caretta e Elis Caretta pelo exemplo, motivação e incentivo diante dos desafios.

Aos amigos, Robson Batista dos Santos Hasmann, Robsom Manuel Nascimento Silva, Maria da Piedade Soares Cóstola, Silvia Leticia Rivero Meza e Débora Duarte dos Santos.

À Capes, pela concessão de bolsa de mestrado. 


\section{RESUMO}

FRANCO, Gabriele. O cruzamento de vozes narrativas em La caída de Madrid, de Rafael Chirbes. 2017. 102 f. Dissertação (mestrado) - Faculdade de Filosofia, Letras e Ciências Humanas, Universidade de São Paulo, 2017.

Esta dissertação tem o objetivo de examinar a construção da memória social como resultado de um confronto de relatos. A hipótese que a orienta é a de que o cruzamento de vozes narrativas possibilita uma multiplicidade de interpretações do passado histórico. Para verificála, o trabalho concentra-se na análise das formas mobilizadas pelo texto para plasmar a consciência dos personagens e figurar o narrador, com a finalidade de compreender de que modo é construída a memória social do período da ditadura espanhola na narrativa. O corpus está constituído pelo romance La caída de Madrid (2000), de Rafael Chirbes.

Palavras-chave: Memória social. Cruzamento de vozes. Narrador. Fluxo de consciência. Ditadura. 


\section{RESUMEN}

FRANCO, Gabriele. El cruce de voces narrativas en La caída de Madrid, de Rafael Chirbes. 2017. 102 f. Dissertação (mestrado) - Faculdade de Filosofia, Letras e Ciências Humanas, Universidade de São Paulo, 2017.

Esta disertación pretende examinar la construcción de la memoria social como resultado de una confrontación de relatos. La hipótesis que la orienta es que el cruce de voces narrativas posibilita una multiplicidad de interpretaciones del pasado histórico. Para verificarla, el trabajo se concentra en el análisis de las formas movilizadas por el texto para plasmar la conciencia de los personajes y figurar el narrador, con la finalidad de comprender como se construye la memoria social del período de la dictadura española en la narrativa. El corpus está constituido por la novela La caída de Madrid (2000), de Rafael Chirbes.

Palabras clave: Memoria social. Cruce de voces. Narrador. Flujo de conciencia. Dictadura. 


\begin{abstract}
FRANCO, Gabriele. The interlacement of narrative voices in La caída de Madrid, by Rafael Chirbes. 2017. 102 f. Dissertação (mestrado) - Faculdade de Filosofia, Letras e Ciências Humanas, Universidade de São Paulo, 2017.

This dissertation aims to examine the construction of social memory as a result of a confrontation of stories. The hypothesis that guides it is that the intersection of narrative voices makes possible a multiplicity of interpretations of the historical past. To prove this hypothesis, the work analyzes of the forms mobilized by the text to represent the consciousness of the characters and to outline the narrator, in order to understand how the social memory of the period of the Spanish dictatorship in the narrative is constructed. The corpus is constituted by the novel La caída de Madrid (2000), by Rafael Chirbes.
\end{abstract}

Keywords: Social memory. Interlacement voices. Narrator. Stream of consciousness. Dictatorship. 


\section{SUMÁRIO}

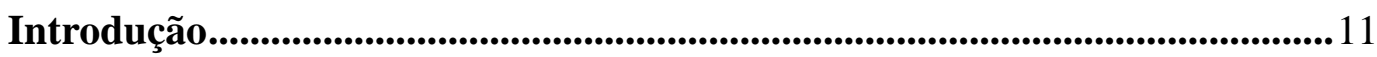

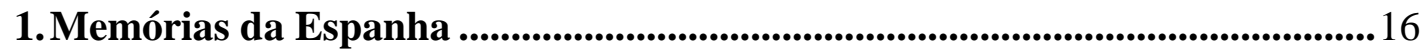

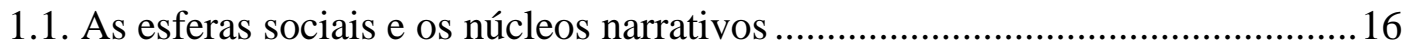

1.2. Técnicas de construção de múltiplas memórias ............................................ 18

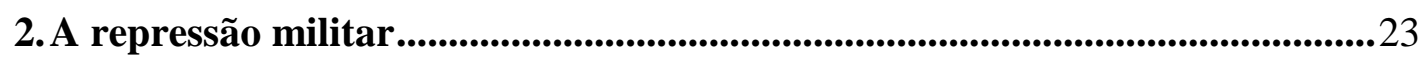

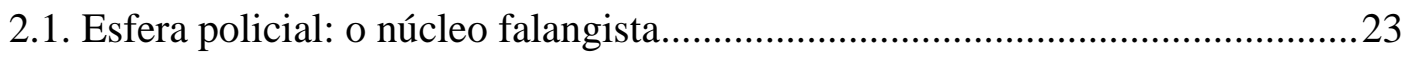

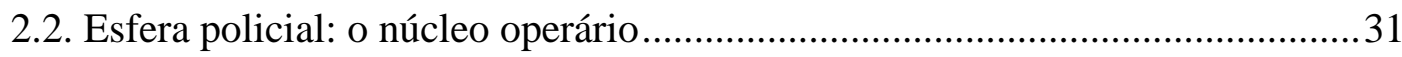

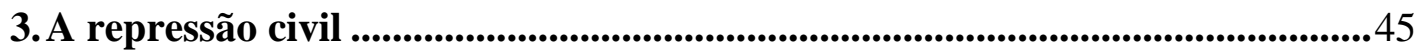

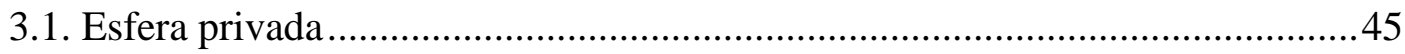

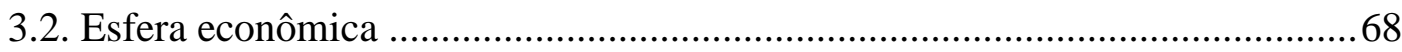

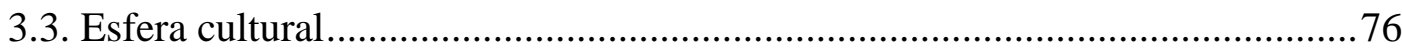

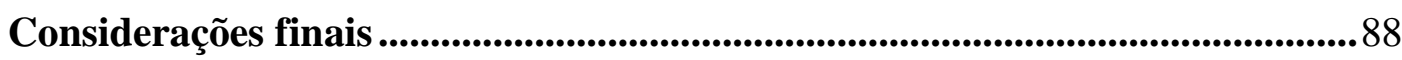

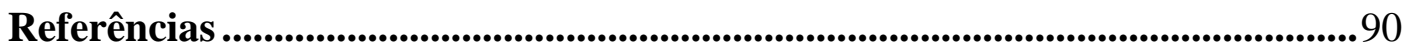




\section{APÊNDICES: FLUXOGRAMAS}

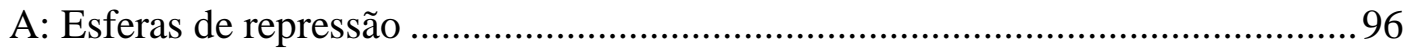



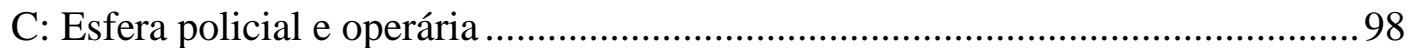

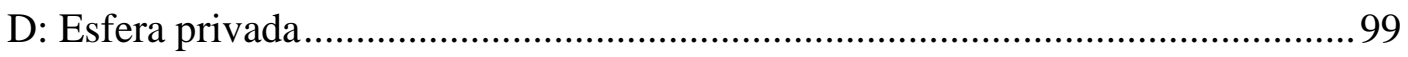

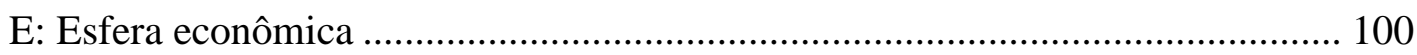

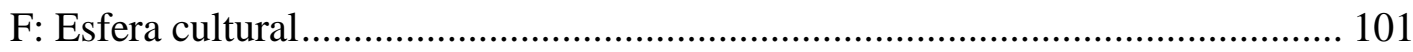




\section{Introdução}

La caída de Madrid é um romance de Rafael Chirbes que nasceu em 1949, em Tabernes de Valldigna, Valência. Ele estudou História Moderna e Contemporânea na Universidade de Madri e dedicou-se à docência, à crítica literária e as atividades jornalísticas. Publicou os seguintes romances: Mimoun (1988), En la lucha final (1991), La buena letra (1992), Los disparos del cazador (1994), La larga marcha (1996), La caída de Madrid (2000), Los viejos amigos (2003), Crematorio (2007), En la orilla(2013) e París-Austerlitz (2016), este publicado postumamente. Foi finalista do Premio Herralde de Novela (1988) e ganhou outros importantes como Premio de la Crítica de Narrativa Castellana (2007), Premio Dulce Chacón de Narrativa Española (2008), Premio de la Crítica de Narrativa Castellana (2013) e Premio Nacional de Narrativa de España (2014). Faleceu em 2015.

Através de suas obras, principalmente da trilogia da qual La caída de Madrid (2000) faz parte, juntamente com La larga marcha (1996) e Los viejos amigos (2003), Rafael Chirbes oferece uma ampla visão do modo como os períodos de barbárie, que englobam a Guerra Civil e a ditadura franquista, transformaram a sociedade espanhola. Daniel Leuenberger comenta a reconstrução do passado individual e coletivo como forma de interpretação da história social da Espanha nos romances de Rafael Chirbes:

Chirbes trabaja sobre el trasfondo histórico, pero no es la Historia, sino la Intrahistoria en el sentido de Miguel Unamuno, la materia principal por la que se interesa en su obra novelística. (Es decir la historia concebida como la experiencia del individuo o de la colectividad ante sus circunstancias históricas; se podría decir que la intrahistoria es una visión de la historia desde los márgenes del poder y tiene como protagonistas a personajes cuya tensión interna resulta en una conciencia del subalterno de un pasado y de un futuro muy distantes a los de la historia oficial.) Nos referimos a la memoria individual (o la memoria colectiva, que resulta de la unión de diferentes memorias de individuos) que reconstruye las distintas historias personales. (LEUENBERGER, 2015, p.4, grifo do autor).

La caída de Madrid está dividida em duas partes denominadas "La mañana" e "La tarde"; a primeira, com nove capítulos, e onze na segunda. Em cada capítulo, um personagem ganha voz por meio de monólogos interiores com a mediação de um narrador onisciente. O título da obra é ambíguo e irônico, pois remete ao fim da Guerra Civil, com a entrada do exército "nacional" em Madrid, no ano de 1939, mas trata de eventos que ocorrem na véspera 
da morte de Francisco Franco, em 1975. Portanto, o enredo se desenvolve enquanto o ditador agoniza no hospital e capta um clima de tensão entre os personagens, pois revela as incertezas sobre o futuro do país: "[...] se esperaba a cada momento la fatal noticia, cuyo enunciado desencadenaría una cascada de acontecimientos de consecuencias relativamente imprevisibles [...]" (CHIRBES, 2000, p.49).

A trama é construída a partir de dois nós interdependentes. O primeiro, e mais importante, envolve a família Ricart e está relacionado com a preparação dos personagens para a festa de aniversário de José Ricart. O segundo nó envolve o mundo do trabalho e dos subalternos, representado por meio da perseguição de Lucio e Enrique pela polícia franquista. Os personagens vivenciam, de forma direta ou indireta, o cotidiano da família Ricart.

Vale destacar que o primeiro capítulo do romance inicia-se com o relato de José Ricart e a partir de suas lembranças surgem os relatos de outros personagens, formando a teia narrativa. Alguns deles são convidados para a festa, outros estão socialmente relacionados com sua preparação. Ninguém realmente deseja comparecer ao evento e comemorar, nem mesmo o aniversariante, pois a expectativa em relação à morte de Franco gera incerteza, angústia e a necessidade dos personagens reexaminarem o passado e se perguntarem sobre o futuro.

Nesse romance, Rafael Chirbes abordou a ditadura espanhola ${ }^{1}$ a partir do ponto de vista de ampla diversidade social: advogados, prostitutas, operários, sindicalistas, donas de casa, universitários, professores e policiais. Essa característica permite a construção de perspectivas múltiplas, e inclusive contraditórias, sobre o mesmo referente histórico, resultando na construção de uma memória social da Espanha no período da ditadura franquista.

Embora os personagens tenham voz há lapsos e descontinuidades em seus relatos. Isso se deve a um momento histórico, no qual os sujeitos sociais eram perseguidos ou tinham suas liberdades individuais extremamente controladas. Segundo as observações de Manuel Hierro (2015, p. 240, grifo do autor):

El lieux de mémoire de la guerra civil es transmitido de padres a hijos deficitariamente, debido a la política de exterminio de la memoria y la sustitución de la historia por el franquismo y sus instituciones, imponiendo una visión de la historia desde la que construir una nueva España salida de la Guerra Civil.

\footnotetext{
${ }^{1}$ Consideramos que, como entende Sabine Schmitz (2006), La caída de Madrid não só extrapola o conceito genérico de romance histórico como apresenta uma versão alternativa para ele, pois permite interpretar a história social presente à luz de uma reconstrução do passado traumático: "Chirbes pone allí [La caída de Madrid] de manera explícita sobre el tapete el concepto genérico de novela histórica y diseña al mismo tiempo una versión alternativa de la 'nueva novela histórica'." (SCHMITZ, 2006, p.201).
} 
O poder exercido pela ditadura era estabelecido através da repressão e do medo. Na narrativa, a cultura do silêncio torna-se evidente e expressa a asfixia que o regime franquista projetava em diversos setores da sociedade: "No poder hablar. Hablar solo con uno mismo." (CHIRBES, 2000, p.270). Segundo Encarnación García de León (2006, p.41), Rafael Chirbes aborda o processo de esquecimento da história e o relaciona com o medo:

El miedo, por suave que sea, siempre es resorte del dolor. En muchos casos, el miedo al dolor, la aceptación de que el dolor impide vivir el presente, fructifica en un juego de silencios que no hace fácil la compresión de los avatares que han provocado reacciones y han conducido a situaciones concretas.

Sendo assim, La caída de Madrid é um convite para uma reflexão sobre a história da Espanha a partir de várias perspectivas, sobretudo aquelas marginalizadas pela história. A representação do fluxo de consciência e a presença do narrador onisciente são uma forma de acessar a memória dos personagens e a totalidade destas memórias permite uma variedade de interpretações do momento social, político e histórico do final do franquismo.

Visto que a narrativa apresenta um tom de asfixia, a divisão dos capítulos dessa dissertação foi organizada em torno dos elementos de controle social explicitados no romance. O regime exerceu dois tipos de repressão sobre a Espanha, a civil e a militar. A repressão militar não se deu somente na Guerra Civil, mas estendeu-se durante todo o período ditatorial através da tortura e violência física praticada pela polícia franquista na detenção dos presos políticos. A repressão civil tinha diversos mecanismos, se alastrou do espaço público para o privado, atuando nas famílias, na economia e no meio cultural. Vale ressaltar que esses espaços eram responsáveis pela dinâmica do regime, visto que possuíam capacidade de conservar e propagar o autoritarismo hierárquico. As duas faces repressivas do franquismo eram interdependentes: “... la represión cumplía en el campo franquista una función política fundamental, ligada a las necesidades de una guerra de clase de los menos contra los más: la de paralizar el enemigo por el terror." (FONTANA, 1986, p.18). Por isso, organizamos a dissertação em três capítulos: o primeiro consiste em estabelecer as relações entre a estrutura do romance, o papel do narrador e a representação do fluxo de consciência com a construção da memória; o segundo apresenta a análise da repressão militar e o terceiro refere-se à repressão civil. 
No primeiro capítulo apresentamos a composição do enredo, as técnicas de representação do fluxo de consciência como recurso de construção da memória. O romance apresenta uma diversidade de personagens e para melhor compreensão das relações entre eles dividimo-los em núcleos narrativos que se distribuem entre as esferas da obra, como a econômica, a cultural, a privada, a policial e a operária. Procura-se descrever como a representação da consciência dos personagens desses núcleos e a interação do narrador onisciente compõem o enredo que se desdobra em dois tempos narrativos: o interior, ou da subjetividade, e o tempo do mundo objetivo.

Após tecer considerações sobre a composição do enredo e dos personagens apresentaremos, no segundo capítulo, a dinâmica de controle exercida pela repressão militar. Através dos personagens que compõem a esfera policial e a operária apresenta-se o conflito violento entre a polícia franquista e a classe operária. Nesse capítulo nos deteremos na análise dos desdobramentos temporais, visto que é através dessas nuances do enredo que se revela a repressão.

No terceiro capítulo analisaremos as esferas em que se exerceu a repressão civil, como a família, a economia e a cultura. Ressaltamos os movimentos do narrador, pois ele acentua o contraste de perspectivas. Cada um desses tópicos é abordado separadamente. Iniciamos com a influência que o regime exerceu no espaço privado, através dos relatos dos membros da família Ricart. Daremos ênfase à função da mulher no espaço doméstico, bem como a relação entre repressão e gênero. Abordaremos a esfera econômica durante o franquismo através de personagens que atuam como advogados, empresários, economistas e operários. Além disso, analisaremos o duplo papel que exercia a cultura, o controle intelectual e a luta por liberdade no ambiente universitário e artístico. Nesse contexto, retomaremos as personagens femininas sob o enfoque da dominação cultural através da novela rosa, bem como relatos dos personagens relacionados ao âmbito da universidade, como professores e alunos.

Há alguns anos, há amplo interesse acadêmico e editorial pela temática do resgate da história, principalmente quando envolve acontecimentos traumáticos, como guerras, exílios e ditaduras. Em tal campo de estudos já se debruçaram críticos para examinar a obra de Chirbes e, entre eles, os que mais se relacionam com este trabalho foram publicados em um dossiê na Revista Turia (2015): "Ficción de la memoria en La larga marcha y La caída de Madrid", de Manuel Hierro e "Traición y memoria. Los disparos del cazador", de Sara Santamaría Colmenero. Destaca-se o ensaio de Sabine Schimitz, publicado em Ensayos sobre Rafael 
Chirbes (2006) e intitulado "La caída de Madrid, una novela histórica de Rafael Chirbes o el arte nuevo de cometer un deicidio real(ista) en el siglo XXI".

Os estudos contemporâneos apresentam uma grande preocupação com as estratégias narrativas utilizadas por Rafael Chirbes, tais como a multiplicidade de vozes e perspectivas que se instauram na obra e, sobretudo, a forma bastante original com que se rememora o passado. Contudo, apesar de a grande maioria dos estudos críticos sobre Rafael Chirbes apontarem para o realismo, a imagem de Madrid na modernidade, a crise na Espanha e a construção da memória histórica, não foram encontrados estudos acadêmicos que se debruçassem com mais fôlego sobre a função que os monólogos interiores e o narrador onisciente desenvolvem na construção da multiplicidade de interpretações do passado histórico em La caída de Madrid. 


\section{CAPÍTULO I}

\section{Memórias da Espanha}

\subsection{As esferas sociais e os núcleos narrativos}

La caída de Madrid conta com enredos paralelos em que os personagens realizam uma revisão do passado. Eles podem ser reagrupadas em seis núcleos: central, falangista, doméstico, operário, universitário, econômico (ANEXO 2). Esses núcleos permitem desenhar quatro esferas sociais: privada, policial, econômica, cultural (ANEXO 1).

A esfera privada (ANEXO 4) situa-se nos espaços domésticos e de convivência das distintas famílias que integram diferentes núcleos do enredo. Entre eles destaca-se o da família Ricart, em que se encontra José - fio condutor do romance - e abre vetores de relação com os demais núcleos domésticos, nos quais o protagonismo cabe às mulheres. Desse modo, as mulheres, seus maridos e filhos compõem as relações na esfera privada e destaca-se o papel social da mulher no ambiente doméstico.

Olga é casada com Tomás Ricart e vive com ele, os filhos e os sogros numa mansão. Amélia é a sogra de Olga, uma senhora que foi enclausurada em casa, enquanto a doença de Alzheimer definha sua mente. Elvira e Sole são as amigas de infância de Olga e suas lembranças apresentam a história da família Ricart de uma perspectiva distinta à dos relatos daquela. Margarita é filha de Elvira e ambas apresentam um conflito de gerações. As empregadas da casa, Pepa e Rosa, não têm voz e aparecem apenas nos diálogos com Lurditas, a cozinheira e esposa do operário Lucio. Ainda na esfera da vida privada, há Carmen e Lina, respectivamente mulher e amante do delegado Arroyo. Carmen não teve filhos devido a problemas genéticos do marido e foi condenada por ele a uma vida de violências e humilhações. Lina é uma garota de programa que se relaciona com o delegado e também é vítima de seu comportamento agressivo.

A esfera econômica é protagonizada pelo estado franquista que controla todas as atividades econômicas e configura dois aspectos das relações de trabalho: a pública e a empresarial. A pública é representada por funcionários diretamente ligados ao governo, como a polícia, os funcionários do metrô e os ministros, entre outros. Dentre eles, destacam-se os personagens do núcleo falangista, responsáveis por impor a ordem que sustentava o regime, e 
os funcionários envolvidos em trabalhos internos à burocracia do Estado, como Prudencio. Ele é caracterizado por sua avareza e é subordinado aos Ministros da Opus Dei.

A atuação empresarial não se compõe somente de personagens do núcleo econômico, pois há outros tipos de atividades comerciais como o mercado de arte, vendedores, a polícia e os operários do metrô (ANEXO 5). O empresário José Ricart protagoniza o mercado empresarial e é subordinado ao Estado porque sua empresa só se mantém devido aos contratos ilegais que são facilitados pelo governo. Além disso, José está ligado a Maximino, não apenas pela relação de amizade, mas também pelos negócios ilegais, pois o delegado o ajudou a colocar dinheiro fora do país. Nesse espaço apresentam-se os funcionários de alto cargo na empresa Ricartmoble, como o economista Tomás Ricart, o administrador Julio Ramirez e o gerente Àlvaro Céspedes. Destaca-se o advogado Jesús Taboada que é visto por José como uma possibilidade para o futuro, pois ele pode atuar como mediador entre empresários e operários. Destaca-se ainda o mercado de obras de arte, suposta fonte ilegal da fortuna da família Ricart, e que, no presente está representada através das relações de Olga e Ada. Lurditas e Pepa, as empregadas da família, também têm um papel na economia e estão ligadas a José Ricart através de um vinculo empregatício. O estudante Lucas se encontra no espaço econômico, pois faz trabalhos secundários em uma loja para manter-se na faculdade.

A esfera cultural reúne núcleos de personagens que atuam nos espaços culturais no final do regime (ANEXO 6). Destaca-se o papel da universidade, do movimento estudantil e artístico, bem como os produtos culturais voltados para as massas e promovidos pela ditadura com a finalidade de continuar a divulgar seus valores. Portanto, esse âmbito está composto pelo núcleo universitário e por algumas personagens do núcleo doméstico. O núcleo universitário apresenta a dinâmica da universidade no fim da ditadura e é composto pelo reitor, pelos professores Bartos e Chacón e pelos alunos Quini, Coronado, Pedro, Lucas e Margarita. Este núcleo reflete o espaço universitário no fim do regime e os principais anseios da jovem geração. Entre eles estão, Margarita e Quini, alunos de classe alta que discutem sobre as greves e os direitos trabalhistas, mas levam uma vida luxuosa e são sustentados pelos pais, sem nenhuma preocupação em exercer alguma de profissão. Mas, entre eles estão também Pedro, Lucas e Coronado, alunos que trabalham para manter os estudos.

Nesse âmbito, retomamos a análise de alguns personagens do núcleo doméstico sob a ótica cultural: Ada, uma artista renomada e empenhada na militância antifranquista; Olga, organizadora da fundação de arte da família Ricart e também compradora dos quadros de Ada. Vinculadas à cultura de massas estão: Elvira, Carmen e Olga, mulheres cujo repertório 
cultural aponta para o papel social da mulher como uma frágil dona de casa que precisa de um herói para salvá-la. Além disso, destaca-se Jesús Taboada, uma ponte entre a cultura de minoria e a cultura de massa, pois recorre a seus conhecimentos de filosofia e sociologia para manipular Lucio e ampliar uma célula revolucionária.

A esfera policial compõe-se da relação entre os núcleos dos operários e o falangista (ANEXO 3). O protagonista desse grupo é o delegado Maximino Arroyo, uma autoridade da polícia franquista e o melhor amigo de José Ricart. Trata-se de um homem cruel que além de torturar e assassinar prisioneiros políticos, violenta sua esposa Carmen e sua amante Lina. Guillermo Majón e Leonardo são policiais subordinados de Maximino e também representam o regime. Ao dar voz a esses personagens, nota-se que até mesmo os representantes da polícia franquista sentiam-se asfixiados pelas autoridades do regime, pois não podiam questionar as ordens recebidas.

Em contraponto ao núcleo falangista está o núcleo operário, composto por Lucio e seus amigos Enrique Roda, El Viejo e Ezequiel. Lucio e Enrique haviam sido funcionários do metrô, perseguidos políticos, acusados de fazer greves e colocar explosivos em trens. Os personagens El Viejo e Ezequiel não têm voz narrativa, mas são referências constantes no núcleo operário. Através da representação destes personagens, Rafael Chirbes cede espaço para as vozes que por muito haviam sido silenciadas, vozes que podem ser entendidas como o lado marginalizado pela sociedade.

\subsection{Técnicas de construção de múltiplas memórias}

O relato e as rememorações de personagens tão diversos permitem uma multiplicidade de interpretações do passado histórico. No entanto, a complexidade do romance não se resume à questão da pluralidade de perspectivas ${ }^{2}$ apresentadas através da representação do fluxo de

\footnotetext{
${ }^{2}$ A perspectiva múltipla é denominada por Rafael Chirbes como efeito boomerang: "Del cruce de miradas, del intercambio de puntos de vista que - en un movimiento de retorno, como de boomerang - aguzan y ponen en cuestión los propios puntos de vista y la mirada del lector, extrae lo mejor de sí misma la narrativa, su carácter de experiencia a la vez pedagógica y ética, lo que reclamaba de ella Walter Benjamín: en ese juego de perspectivas, el lenguaje se libera de cualquier transcendencia, se convierte en instrumento relativista de cada personaje, se limpia de las rebadas que el uso y la manipulación han puesto sobre él, se repristina la mirada a la vez del autor y del lector, redescubriendo el mecanismo por el que cada palabra busca ser nombrada. (CHIRBES, 2010, p.26)". Essa técnica também é uma característica de outros romances de Rafael Chirbes, como En la lucha final (1991), La larga marcha (1996) e Los viejos amigos (2003). Segundo Fernando Valls (2015, p. 131): "El narrador se vale, en fin, de sus testimonios, de una polifonía de voces distintas que se complementan, para componer la novela.".
} 
consciência, pois há o narrador onisciente que atua como condutor dos relatos e interpela o leitor.

Percorremos a estrutura do texto, refazendo os caminhos do narrador, dos monólogos e observando quais os recursos e as técnicas utilizados para que o fluir da consciência ganhe textura narrativa e rememore a história da Espanha. Com a finalidade de distinguir os procedimentos usados na instância da narração, focalizamos quatro aspectos: memória ${ }^{3}$, temporalidade ${ }^{4}$, representação do fluxo de consciência ${ }^{5}$ e o narrador ${ }^{6}$, seguindo uma linha inspirada em uma leitura que Ricoeur faz de Hallbwachs: “...Para acordarse, uno debe colocarse en el punto de vista de uno o varios grupos y situarse en una o varias corrientes de pensamiento. (HALBWACHS, 1980, p. 63 apud RICOEUR, 2003, p.159-160).”

La caída de Madrid apresenta os relatos de personagens de meios sociais diversos que rememoram com outros indivíduos, compartilham, comunicam e modificam as imagens do passado ao apropriarem-se delas como recordação. $\mathrm{O}$ ato de rememorar permite que o enredo desdobre-se em dois tempos: o tempo do mundo objetivo e o interior ou da subjetividade ${ }^{7}$.

No tempo do mundo objetivo, o enredo desenvolve-se em algumas horas, entre as seis da manhã e as oito da noite do dia 19 de novembro de 1975. Ele se estrutura em torno das expectativas sobre a morte de Francisco Franco, dos preparativos da festa de aniversário de José Ricart e da perseguição de Lucio e Enrique. O tempo da subjetividade desenvolve-se enquanto os personagens pensam sobre a festa, rememoram suas vidas ou indagam-se sobre o

\footnotetext{
${ }^{3}$ Com a finalidade de nos aprofundarmos no processo de construção da memória transitamos entre as leituras teóricas de La memoria, la historia, el olvido (2003), de Paul Ricoeur, A memória coletiva (2009), de Maurice Halbwachs, La memoria de los olvidados (2004), organizado por Pancho Salvador e Magia e técnica, arte e política (1987), de Walter Benjamin. Para compreender como as questões da memória histórica se aplicam ao contexto da ditadura de Francisco Franco recorremos a um repertório de leituras sobre a história da Espanha. Dentre as obras lidas, destaca-se: História de Espanha (1980), de Pierre Vilar, Historia Mínima de España (2012), de Juan Fusi e España bajo el franqusimo (1986), organizado por Josep Fontana. As obras auxiliaram na contextualização do processo histórico. Além disso, as leituras dos romances de Rafael Chirbes também favoreceram a contextualização da narrativa e a familiarização com o estilo do autor, pois a relação entre a memória coletiva e individual está presente em quase todas os romances de Rafael Chirbes, como La buena letra (1992), Los disparos del cazador (1994), La larga marcha (1996), Los viejos amigos (2006), Crematorio (2007), En la orilla (2013).

${ }^{4}$ Como embasamento teórico para a análise da temporalidade recorremos à obra Tempo e Romance (1972), de Adam Abraham Mendilow.

${ }_{5}$ Para investigar os procedimentos do fluxo de consciência utilizamos como suporte teórico e guia para as análises a obra La corriente de la conciencia en la novela moderna (1969), de Robert Humprey.

${ }^{6} \mathrm{O}$ narrador onisciente de La caída de Madrid não é apenas um recurso para representar o fluxo de consciência, mas um condutor do enredo que percorre a consciência dos personagens realizando interpelações. Como referência teórica para explorar a figura desse narrador selecionamos o conceito de "terceiro autor implícito" presente na obra A retórica da ficção (1980), de Wayne C. Booth.

${ }^{7}$ Segundo Mendilow (1972, p. 240), a ação em um romance de enredo, já que afeta muitas pessoas ou que pelo menos é potencialmente capaz de ser notada por outras pessoas, deve desenvolver-se no tempo objetivo que serve como denominador temporal comum para todos. Estados subjetivos, contudo, têm seus próprios modos de duração e de sucessão.
} 
futuro após a morte de Franco. Este tempo interior tem maior flexibilidade e engloba um período histórico que começa na Guerra Civil e se estende a suposições do futuro.

O passado é representado na narrativa através das rememorações dos personagens e intervenções do narrador, portanto pertence ao tempo subjetivo e é contrastado com o tempo objetivo. Assim, pensamentos e emoções imprimem ritmos variados de duração de tempo, embora seja possível projetá-los contra os pontos do tempo objetivo do presente fictício ${ }^{8}$.

Apesar de ser indicado através de tempos verbais do pretérito, como o pretérito perfeito do indicativo, o ponto de referência do tempo objetivo compreende um intervalo de horas, entre as seis da manhã e as oito da noite, como um presente fictício. Os tempos objetivo e subjetivo podem ser determinados pelo contexto narrativo, pelo conteúdo e também pela estrutura temporal. Realizamos uma análise minuciosa e constatamos que os tempos verbais mais recorrentes na obra são o pretérito perfeito do indicativo, o pretérito imperfeito e pretérito mais que perfeito composto. No tempo subjetivo recorre-se com maior frequência ao pretérito imperfeito e ao pretérito mais que perfeito composto, pois se trata de um momento de rememorações dos personagens, bem como de descrições e interpelações do narrador. $\mathrm{O}$ pretérito imperfeito descreve a história, como se a cena fosse observada e narrada e o pretérito mais que perfeito composto apresenta e explica as ações desenvolvidas no passado. No tempo objetivo destaca-se o pretérito perfeito para apresentar informações ou um acontecimento, fazendo com que a narrativa avance. Essa estrutura temporal apresenta exceções diante dos diálogos, em que os verbos no presente do indicativo são utilizados com maior frequência.

A mescla entre o nível objetivo e o subjetivo conduz o andamento da narrativa, gerando a sensação de angústia que prevalece na obra do princípio ao fim. Verifica-se esse sentimento em todos os personagens, mesmo quando não há referência direta à saúde debilitada de Franco todos se encontram em alerta. $\mathrm{O}$ suspense em relação àquilo que acontecerá após a morte do ditador não é desfeito e estende-se até o final da obra ampliando a tensão narrativa, sempre mantida pelo silenciamento, pois os personagens sentem-se censurados e reprimidos em todos os âmbitos sociais. O ambiente de repressão e silenciamento concentra-se no tempo subjetivo e é capturado pela corrente de consciência através do uso do monólogo interior direto $^{9}$ e indireto ${ }^{10}$.

\footnotetext{
${ }^{8}$ De acordo com Mendilow (1972, p.109), o passado em que a maioria dos romances é escrito representa um complexo de seus diferentes graus. Há um ponto de tempo na estória que serve como ponto de referência. $\mathrm{O}$ presente fictício pode ser considerado como tendo começo nesse ponto.

${ }^{9}$ Segundo Humphrey (1969, p.39), a linguagem do narrador no monólogo interior direto funde-se com a linguagem do personagem: "Pueden existir variantes, sin embargo. La más frecuente se produce cuando el autor se hace presente en la narración a modo de guía o comentador."
} 
Em La caída de Madrid, o narrador ${ }^{11}$ atua de forma diferenciada, como um condutor da narrativa que percorre a consciência dos personagens e transita entre o nível subjetivo e objetivo colaborando com o desdobramento temporal. O narrador não só acrescenta informações à perspectiva dos personagens, visto que sabe aquilo que sentem, mas também apresenta a sua perspectiva. Suas interpelações tornam-se evidentes através dos marcadores textuais de parênteses, pois o narrador interrompe a descrição para dirigir-se ao leitor. Essas características são denominadas por Wayne C. Booth (1980) como um "terceiro autor implícito".

A perspectiva do narrador não é rígida, flexibiliza-se porque ora se aproxima e, inclusive, adere à perspectiva do personagem e ora se afasta. Ele se move para trás e para frente, explorando o passado e o futuro através de sensações, sentimentos, indagações e rememorações. A mobilidade do narrador entre os níveis temporais articulam a transição do enredo de um nível para o outro, dissolvendo as marcas temporais. Mesmo com as alterações na estrutura verbal da narrativa nem sempre é possível determinar com precisão os limites entre os monólogos e a descrição onisciente, nem tampouco o momento exato do desdobramento temporal, pois há um período de transição entre eles. São estes períodos de transição que marcam as oscilações de um nível narrativo para outro, acentuando o efeito de fragmentação e conferindo complexidade à representação da consciência.

Desse modo, a mudança de perspectiva entre os personagens e a presença do narrador é realizada por um processo de transição, marcado pela sutil transformação da sintaxe por meio do uso de figuras de estilo, mudança na pontuação, marcas tipográficas e mudança do tempo verbal. Essa mescla entre os relatos dos personagens e do narrador permitem o efeito de mobilidade de perspectivas. Vale ressaltar que as lacunas deixadas pelos personagens não são completamente preenchidas pelo narrador. Dessa forma, cria-se o efeito de fragmentação da narrativa, como um espelho quebrado e cabe ao leitor juntar as partes.

Além da presença do narrador e dos monólogos, são utilizadas outras técnicas para representar a consciência, como a associação de ideias e a representação da fala. A associação livre de ideias mostra-se como uma técnica destinada ao controle do movimento da

\footnotetext{
${ }^{10}$ De acordo com Humphrey (1969, p.41), o monólogo interior indireto é: “ [...] aquel en el cual un narrador omnisciente presenta un material no articulado oralmente como si proviniera directamente de la conciencia del personaje, conduciendo el lector a través de él y ayudándole con comentarios y descripciones."

${ }^{11}$ A técnica que Rafael Chirbes aplica ao narrador é aprimorada no romance Crematorio (2007). Além disso, vale destacar o comentário de Fernando Valls sobre o narrador: "El autor se vale de un narrador omnisciente que va cediendo voz a los personajes, mostrándonos, mediante el estilo indirecto libre, sus razones o sinrazones. (2015, p.141)."
} 
consciência e permite a transferência de eventos para o plano mental, dispensando a sequência cronológica e mantendo a continuidade. Três fatores controlam a associação: a memória que constitui sua base, os sentidos que a guiam e imaginação que determinam sua elasticidade.

O efeito que Abraham Mendilow (1972, p. 126) denomina como "fala representada" é um modo de preservar o diálogo direto sem sacrificar as vantagens que acompanham a narração onisciente, reforçando o efeito de ilusão do presente. Durante a rememoração de um fato, utiliza-se o discurso direto, com tempo verbal no presente do indicativo com a finalidade de transmitir a sensação de que a lembrança é tão intensa que o personagem revive o momento. O uso de marcadores textuais como " $<<>>$ " também expressam o discurso direto, fazem referência a uma fala que o personagem rememora de modo menos profundo do que os diálogos representados em discurso direto. Esses marcadores também atuam como referências do narrador em relação aos pensamentos dos personagens. Nesse caso, são introduzidos após verbos como "pensó" ou "pensaba". Além disso, a imaginação realiza o movimento na direção contrária e supõe o futuro. Nesses casos, são introduzidos verbos no futuro do pretérito.

Portanto, os procedimentos de representação da textura da consciência, a mobilidade do narrador e a diversidade de relatos permitem uma multiplicidade de interpretações do passado histórico da Espanha. Eles viabilizam o cruzamento de vozes narrativas, cruzamento que possibilita a construção da memória social, explicitando o caráter provisório da reconstrução do passado. 


\section{CAPÍTULO II}

\section{A repressão militar}

\subsection{Esfera policial: o núcleo falangista}

Após a Guerra Civil, a ditadura de Franco impôs-se através de práticas de controle social, sempre sustentadas por discursos que mantinham a divisão entre vencidos e vencedores $^{12}$. Essa divisão está encarnada nos núcleos de personagens do romance, principalmente na esfera policial e operária, e é a motivação da tensão narrativa (VER ANEXO 3).

O grupo nacionalista venceu a Guerra Civil, mas era composto por diferentes forças como, falangistas, carlistas, alfonsinos e corporativistas católicos que diferiam em suas metas ideológicas. Desse modo, a lei que dissolvia os partidos políticos de oposição também afeta aqueles considerados vencedores. Franco deseja perpetuar-se no poder, mas alguns dos simpatizantes do regime desejavam substituí-lo. Por isso, a repressão também era imposta entre os partidários do regime. Segundo Sheelagh M. Ellwood (1986, p.43):

El decreto número 255, llamado de Unificación de Partidos, del 19 de abril de 1937, unía falangistas y carlistas en un solo partido (FET y de las JONS), disolvía todas las demás organizaciones políticas y nombraba a Franco jefe nacional de la nueva entidad.

Não só por leis se impunha o regime. O recurso imediato depois da guerra foi a força do exército e da policia nacional. No romance, a ação repressiva da ditadura é o cerne da construção do personagem Maximino Arroyo. Ele protagoniza o núcleo falangista ${ }^{13}$, pois representa o membro de maior autoridade da polícia franquista e atua como elemento

\footnotetext{
${ }^{12}$ Eram considerados vencidos aqueles que não pertenciam ou não haviam apoiado o Bando Nacional e os vencedores eram aqueles que lutaram ao lado de Franco e o apoiaram. Essa divisão da sociedade espanhola é explorada no livro La memoria de los olvidados (2004), especialmente no segundo capítulo, intitulado, "Vencidos y olvidados".

${ }^{13}$ O termo "falangista" foi utilizado para classificar os personagens que atuam na polícia ou apresentam alguma relação com a repressão física e moral estabelecida pelo regime. No entanto, vale destacar que se trata de um termo bastante amplo que engloba diferentes categorias e facetas de um grupo responsável por manter o controle do sistema político durante o franquismo.
} 
repressivo contra a crescente inquietude política, social e intelectual. Subordinados ao delegado encontram-se os policiais Guillermo Majón e Leonardo que recebiam suas ordens, sua esposa Carmen e sua amante Lina. A esposa e a amante são subordinadas, assim como os militantes, pois são tratadas com a mesma violência aplicada na perseguição e captura dos militantes Lucio, Enrique e El Viejo.

Através da descrição onisciente do narrador e das rememorações do personagem sabe-se que a atuação de Arroyo em favor de Francisco Franco começa durante a Guerra Civil: "Durante la guerra, había tenido que verse en situaciones muy delicadas, y no había temblado, había estado a punto de que lo mataran varias veces y se había visto obligado a matar como cualquier soldado en guerra. (CHIRBES, 2000, p. 63).”

A ideia de vencedores e vencidos estabelecida após a Guerra Civil é representada por Arroyo através de sua perspectiva determinista. Ele se comporta como se as relações sociais funcionassem como uma "cadeia alimentar", em que a vontade do mais forte ou poderoso prevalece. Sendo assim, para Arroyo a sociedade é como um "ecossistema” onde indivíduos de distintas classes se encontram em um processo dinâmico de ações e sua função nesse processo é estabelecer a ordem. Aqueles que estão subordinados a ele são tratados como "caças" numa relação entre predadores e presas. Ele representa a obsessão da ditadura pelo controle social e pelas práticas repressivas:

Aunque también habría que preguntarse alguna vez qué era exactamente el orden; qué partes del animal habría que esconder y cuáles no; a cuáles debía entregarse el hombre sin dejar de ser hombre y convertirse en bestia, y de cuáles tenía que librarse para no retroceder en la escala zoológica; de qué partes del animal no podría librarse por más que lo quisiera. Alma sí, pero también cuerpo, y hasta dónde debía mandarla una sobre el otro, o viceversa. (CHIRBES, 2000, p.62).

Lo mismo los hombres que los animales: porque había campesinos - y eso turbaba aún más al niño - que asaltaban a la Mosca por la espalda y se movían sobre su lomo exactamente igual que si fueran perros. Pero era, sobre todo, el interior del cerdo y, por fuera, su piel suave y sonrosada después de que la chamuscaran con ramas de tojo encendidas, lo que hizo pensar desde muy joven en la identidad entre animales y personas, por más que, luego cuando se murió su padre, su madre consiguiera que, mediante la influencia del párroco, lo enviaran al seminario para estudiar bachillerato elemental, $y$, allí, los curas se empeñaran en enseñarle que había que separar del reino animal al ser humano poniéndolo en un peldaño de la escala zoológica distinto y más elevado. (CHIRBES, 2000, p. 60).

Para o delegado, homens e animais são muito parecidos e há uma dualidade entre fera e humano que só encontra seu equilíbrio através da ordem. Vale ressaltar que a hierarquia social 
era um modo de dominação que assegurava o poder do ditador. Arroyo ocupa o topo da hierarquia de órgão repressor, pois sua posição como delegado da polícia franquista lhe confere poder. $\mathrm{O}$ alcance da repressão transcende a finalização da guerra e é representado através do comportamento de Arroyo que considera a violência como uma parte constitutiva de seu trabalho, sendo assim, ele a exercia com frieza:

Maximino pensaba que, a veces, dando más, se da menos. Ocurría en
muchas otras actividades. En el comercio, dónde más valor pueden tener las
palabras con las que se cierra un trato que la firma al pie del talón con el que
se paga, y que a lo mejor no tiene fondos; en la propia brigada, dónde no se
trataba de amenazar más, ni de golpear más, sino de hacer exactamente lo
que se tenía que hacer. Un grito de más podía llevar al silencio al acusado;
podía darle un punto más de miedo, que se convertía en cerrazón; un golpe
de más podía hacer renacer el orgullo que el trabajo de muchas horas había
reducido a escombros. (CHIRBES, 2000, p. 58).

A violência física praticada por Maximino Arroyo tinha respaldo e era encoberta pela igreja, umas das principais instituições do franquismo, delatando aqueles que se opunham ao regime, pois eram considerados pecadores. Segundo as palavras de Daniel F. A. Espinosa (2003, p.72): "Porque era la iglesia quien denunciaba en las pequeñas parroquias a las personas que no habían podido escaparse o no habían podido exilarse. Era la iglesia quien acompañaba a los que iban a ser fusilados...". Nota-se na vigilância religiosa uma extensão da repressão que se cultivava em nome Deus. Para Arroyo a religião era uma forma de vigilância e imposição de ordem:

Él veía necesario que existiera la amenaza de que alguien te vigila cuando haces algo y que, si eso que haces es malo, te creas que tienes que pagar por ello. <<Dios le quita mucho trabajo a la policía >>, decía el capellán de la Dirección General de Seguridad. Y él se burlaba: <<Parece que cada vez menos, padre. $>$ Y él capellán le respondía: $<<$ Sin Dios, a lo mejor tenías que vigilarme también a mí. > Y se reían los dos. Su amigo Ricart, que no era muy creyente que digamos, decía justo lo contrario que el cura: $<<$ Vigila más el ojo de un guardia que el de Dios. >> A lo que Maxi respondía: $<<$ Ricart, un guardia sin Dios es un espía ruso. >> Y se reían los dos. Quizá porque los dos sabían lo del envoltorio necesario de una mentira. Vigilancia, atención. (CHIRBES, 2000, p.61-62).

$\mathrm{Y}$, sin embargo, todo aquello que había tenido la desgracia de ver y aprender, no solo no lo había apartado de la religión, sino que le había confirmado la necesidad de una religión, a lo mejor no como esperanza de que luego hubiera un más allá un cielo...pero sí como un conjunto de ceremonias, de ritos (así se llamaban, ritos litúrgicos: liturgia del Adviento, de Navidad, de Cuaresma, de Pentecostés), de normas que domesticaran a ese animal salvaje llamado hombre. (CHIRBES, 2000, p.61). 
$\mathrm{Na}$ narrativa todos aqueles hierarquicamente inferiores a Arroyo eram vítimas de sua violência. Sua autoridade também se refletia nas relações pessoais com a esposa e a amante. Desse modo, a vida pública interferia na vida privada, estruturando as relações de poder e evidenciando a hierarquia. Os fragmentos dos relatos de Lina e Carmem sobre Arroyo somam-se aos fragmentos de Lucio e do próprio delegado acentuando seu lado animalesco e violento, assim como suas fraquezas e frustrações. Carmem se refere a ele como um "perro" ou animal que "muerde": A la mañana siguiente tenía marcas por todo el cuerpo. La mordía hasta hacerle sangre;” (CHIRBES, 2000, p. 295-296). As referências à violência física e psicológica também são recorrentes nas rememorações de Lina: “ [...] no sé que hacer, la pistola, tiene una pistola y dice que es policía, pero ni siquiera eso sé, sé que tengo miedo, que me muerde como si quisiera comerme de verdad, mira, mira la marca de los dientes ahí [...]” (CHIRBES, 2000, p.180).

Arroyo é representado como uma autoridade que exerce o poder com base na violência, porém ele revela o medo do futuro após a morte de Franco em uma conversa com o amigo José Ricart: “Tú, al fin y al cabo, eres empresario. Podrás adaptarte, pero yo soy policía de Franco.” (CHIRBES, 2000, p.50). Uma inversão no cenário político o transformaria em um perseguido. Outra fragilidade do delegado é a dependência de Lina e as crises de ciúmes, como revela a intervenção do narrador em terceira pessoa. Lina e Carmem temem o poder de Arroyo e ele, por sua vez, teme perdê-lo:

No le importaba hacer cualquier trabajo en su despacho, cumplir con su obligación de policía por dura y desagradable que fuese, pero cada vez que pensaba que ella iba a dejarlo [...] Maximino Arroyo se echaba a temblar [...] (CHIRBES, 2000, p. 63-64).

Lucio e Enrique também rememoram momentos de repressão e violência quando se referem a Arroyo. Vale ressaltar que a "caça" aos adversários também era uma forma de silenciar a versão que as testemunhas ou vítimas da ditadura apresentam da história, pois se elas são impossibilitadas de contar, consequentemente, seus relatos destinam-se ao esquecimento. A cultura do silêncio marginaliza aqueles considerados vencidos, fazendo-os sentirem-se fracassados. Para esses personagens o delegado e os agentes da polícia, instrumentos da repressão e do silenciamento, também eram associados a animais e caracterizados como cachorros furiosos que perseguem uma presa:

[...] él corría huyendo de aquellos individuos, que iban a lo suyo, a cazar, más perros que perros, jadeando como los perros, echando humo por la boca como perros, corriendo como lo que eran, perros de dos patas, cabrones de 
perros más malos, peor que los perros, porque los perros buscaban sin saber a ciencia cierta el porqué, y ellos sí que lo sabían. (CHIRBES, 2000, p.313).

O trecho citado pertence ao relato de Lucio, em que se pode observar como o narrador em terceira pessoa transfere sua voz para o registro do fluxo de consciência. A posição das vírgulas e a repetição do termo "perros" imprimem ao relato a sensação de cansaço de alguém que corre e ao mesmo tempo tenta raciocinar, revelando o desespero do personagem. Enrique Roda faz as mesmas associações em relação à polícia quando, durante sua tentativa de fuga, sente-se perseguido "por los ladridos furiosos de un perro" (CHIRBES, 2000, p.28). As características do trecho citado revelam uma aproximação do narrador em relação a Lucio, pois utiliza o monólogo interior indireto para representar a consciência do operário.

Além de Lucio e Enrique, o personagem El Viejo compõe o núcleo operário, representando um dos perseguidos pela polícia franquista. Ele é introduzido na narrativa quando Arroyo lê sua ficha policial, reconhecendo que, assim como os militantes clandestinos, ele se encontra dentro de uma hierarquia e obedece a ordens superiores:

A las diez de aquella mañana, Maxi había conseguido hablar tres veces con
el ministro, y en el despacho habían montado un operativo en torno al
cadáver del tipo de Vanguardia Revolucionaria muerto en el tiroteo, y que
había resultado ser Raúl Muñoz Cortés, alias el Viejo, un antiguo conocido
de la brigada político social, un individuo de casi setenta años que fue
comunista en el batallón de Líster durante la guerra y luego se había salido
del partido y había merodeado por una infinidad de grupúsculos de extrema
izquierda. A Maxi, aquejado de melancolía, cuando le enseñaron la ficha del
pobre diablo que ya era cadáver, le había dado por pensar que también aquel
tipo se había pasado la vida intentando componer las piezas de un
rompecabezas imposible. <<Un imbécil〉>, pensó, y tuvo la sospecha de que
la imbecilidad del otro encontraba un eco en sí mismo. Corrigió el
pensamiento: <<Tan imbécil como yo; tú también le has hecho el trabajo a
otros, como yo se lo hago (CHIRBES, 2000, p.55).

Nesse trecho, retoma-se a ideia disseminada pela ditadura franquista de que aqueles considerados vencidos eram fracassados. Ao retomar a ficha policial de Raúl Muñoz Cortés, o delegado Arroyo apresenta sua perspectiva sobre os acontecimentos da vida do militante assassinado. Embora o considere "un imbécil", reconhece que ambos atuam como mecanismos em um sistema hierárquico de repressão.

Nota-se que o narrador não apresenta afinidade com Arroyo, pois se distancia de sua perspectiva. Esse distanciamento revela-se por meio da estrutura do relato de Arroyo em que há poucas interpelações e não abre espaço para a utilização do monólogo interior direto. Além disso, o relato exprime uma estrutura bem marcada entre tempo objetivo e subjetivo, isto é, os momentos de transição entre a perspectiva do personagem e a do narrador sugerem que o 
narrador não compartilha as mesmas ideias que o delegado. A construção sintática das frases também constrói esse distanciamento, pois quando o narrador precisa referir-se de modo mais direto aos pensamentos de Arroyo utiliza o marcador textual.

O narrador funciona como um guardião das histórias, dos relatos privados de cada personagem. Sua movimentação na narrativa e sua habilidade em aproximar-se e afastar-se das perspectivas dos personagens de acordo com seu grau de afinidade revela que ele tende a compadecer-se daqueles que demonstram interesse ou solidariedade com suas histórias. Desse modo, ele afasta-se de Arroyo, pois como o delegado exerce um papel repressor e violento sobre a sociedade, consequentemente, contribui para o processo de esquecimento após a Guerra Civil. Essa situação torna-se evidente quando Maximino Arroyo e o policial Guillermo articulam um plano para silenciar a família de El Viejo que foi assassinado pela polícia franquista naquela madrugada:

Lo único importante en aquellos instantes era que la familia del difunto aceptaba silenciar que la muerte había sido producida por un disparo. (CHIRBES, 2000, p.55).

Guillermo le había garantizado a la mujer que el Estado iba a indemnizarla por su silencio. $<<$ Mejor pensar que ha sido un error, que no que se vean su hijo y usted implicados en una acción subversiva >>, le había dicho. Para eso Guillermo era un tipo impagable. Listo como el hambre. En cuanto dispuso de los datos (antes de las diez de la mañana), se había presentado en la casa del difunto, había amenazado con involucrar a la mujer y al muchacho en las actividades terroristas del padre $(<<$ Señora, su marido ha muerto con una bomba en la mano $>>$, le había dicho, $<<y$ por qué no pensar que en esta casa pueden encontrarse otras. A veces aparecen con solo buscarlas $>>)$. (CHIRBES, 2000, p. 56).

Após assassinar El Viejo, eles ameaçam a família e inventam uma memória sobre sua morte, uma versão distorcida dos fatos. O silenciamento da família alude ao que foi imposto à sociedade espanhola após a Guerra Civil e durante a ditadura:

Los vecinos sin duda acudirían a la casa cuando se enterasen de la desgracia, y ella tendría que decirles que se trataba de un ataque de corazón: infarto. Se había caído en plena calle, lo habían llevado al hospital, y allí muerto sin que los médicos pudieran hacer nada. Para que todo se cumpliera a rajatabla, el proprio Guillermo y su compañero se turnarían sentándose algunos ratos en las descabalas sillas de anea esparcidas por el comedor de la casuca: <<Unos sobrinos que hemos venido en coche desde Salamanca en cuanto nos hemos enterado de la noticia, señora, eso es lo que somos nosotros $>>$, le habían dicho a la mujer que aceptaba todo, paralizada por el miedo y el dolor [...] (CHIRBES, 2000, p.57). 
O delegado Arroyo define Guillermo como "el mejor agente de la brigada políticosocial" (CHIRBES, 2000, p.56). O policial não observa as circunstâncias que o cercam de forma crítica, pois ignora o verdadeiro alcance de seu trabalho e não se reconhece como um representante da violência e da repressão. Ele se sente incomodado ao receber ordens para matar Enrique Roda, mas não é capaz de relacionar sua angústia ao ato que irá cometer. Associa esse sentimento à cena que presencia ao chegar a sua casa, na qual metaforicamente um gato mata um pássaro:

Se asomó a la terraza y vio que el gato estaba jugando con algo. Al principio le pareció que jugaba con una piedra, o con alguno de los frutos de los árboles cercanos, las bolas peludas de los plátanos que había en la acera, con algo así, pero en cuanto se fijó un poco más, descubrió que no, que jugaba con la cabeza de un pájaro, y también advirtió que al lado estaban las puntas de las alas del animal, que eran pardas, un gorrión, y había algunas pequeñas plumas esparcidas encima de los baldosines. Hasta le pareció distinguir una mancha de sangre al extremo de los pedazos de ala. Buscó algo que se pudiera lanzar contra el gato, para castigarlo, porque la escena lo había perturbado hasta provocarle náuseas. Miró en torno suyo y no encontró nada que pudiera servirle para su propósito, por lo que se internó en la casa. Las alas mutiladas, las plumas le habían traído el nombre del preso, Enrique Roda, y había sentido deseos de vomitar (CHIRBES, 2000, p.264).

Como se observa no trecho citado, o narrador revela pouca afinidade com o personagem, pois não se refere diretamente aos pensamentos de Guillermo e não usa marcadores textuais, apenas descreve um fluxo de pensamentos marcado pela pontuação. Nota-se certa escassez de ponto final e excesso de vírgulas, resultando em construções frasais relativamente longas.

Através do relato, percebe-se que, por um lado, o policial identifica-se com o gato, um predador que mata o pássaro indefeso, representado por Enrique Roda. Ao personificar os animais, Guillermo atribui a eles um sentimento moral que não existe no reino animal e sente a necessidade de repreender o gato. Essa atitude revela que nele também há uma perspectiva determinista, assim como a de Arroyo, pois indiretamente associa sua imagem ao gato de estimação que mata pela necessidade de sobrevivência. Guillermo pretende assassinar Enrique porque essa foi a ordem dada pelo delegado. Desse modo, ele se submete ao domínio de Arroyo e ambos perseguem Lucio e Enrique que são associados por ele ao pássaro morto. Por outro lado, a cena do gato brincando com a cabeça do pássaro produz em Guillermo o mesmo medo da mudança explicitado por Arroyo, ambos temem que os papéis possam inverter-se:

...y recordando la cabeza del pájaro entre las patas del gato, se sentía frágil, tenía ganas de apretar el gatillo para demostrarse que podía hacerlo, y luego tenía ganas de dormir, y era como si también a él pudieran dejarlo tumbado 
entre las basuras que se amontonaban a la orilla del Manzanares, de espaldas a las chabolas de San Fermín. (CHIRBES, 2000, p.275).

Outro medo de Guillermo é produzido por Arroyo que os aterroriza com imagens da Revolução de Portugal e com imagens de estudantes e grupos de operários lançando pedras contra a polícia. O delegado utiliza as imagens como justificativa para a violência e as mortes, das quais são responsáveis, mediante o argumento de que agiam para defender-se:

Arroyo les había estado pasando en su despacho unos días antes aquellas películas en las que se veían imágenes de marineros portugueses que mostraban claves a la gente, y de niños que subían a los tanques con una flor en la mano, y, a continuación, otras imágenes sombrías en las que tipos siniestros perseguían a hombres aterrorizados a los que apaleaban en mitad de la calle. $<<$ Nos persiguen a nosotros, a los policías, a los de la pide, a los de la político-social. Esos que huyen como conejos somos nosotros ¿os dais cuenta?>>, les había dicho, y, luego, sin solución de continuidad, les había puesto las filmaciones que guardaban los archivos, en las que se veía a los estudiantes españoles apedreando a los policías, grupos de obreros persiguiendo a un guardia que sangraba por la nariz, y les había dicho: $<<Y$ eso no es Portugal. Eso es aquí mismo, en Getafe, en la Universitaria, en Atocha. No vamos a dejarlos, ¿verdad? (CHIRBES, 2000, p.272).

Guillermo também se sente fragilizado, isso o leva a refletir sobre o sistema de ordens que imperam sobre sua existência. O personagem não é capaz de refletir sobre a obsessão e imposição de normas, apenas observa como isso afeta sua rotina. Ele acreditava que a ordem é essencial para o bom funcionamento social, pois decide morar com sua namorada, Carmem, quando percebe que ela limpava, cozinhava e organizava a casa. No entanto, a ideia de ordem transformou-se em autoritarismo, pois a moça havia estabelecido várias regras para o funcionamento da casa e ele se sentia obrigado a obedecer. Observa-se que Guillermo não se sentia incomodado com a presença de sua namorada, mas com o fato de receber ordens que não eram justificadas e ter a obrigação de cumpri-las. Sua angústia está relacionada com suas obrigações do trabalho, pois sua tarefa naquela noite era matar Enrique Roda:

Guillermo se decía ahora que el orden había ido asfixiándolo poco a poco. El pantalón bien doblado en la percha, los zapatos en el armario, porque para andar por casa están las zapatillas, las cenas juntos, porque $<<$ si tienes algún servicio imprevisto, me llamas para que esté tranquila〉>, un orden así (CHIRBES, 2000, p.270).

O narrador onisciente revela através do monólogo indireto que Guillermo sentia-se asfixiado pela ordem e pela rotina que lentamente foram se estabelecendo em sua casa e rotina. Essa sensação é uma metáfora para a ditadura, revelando que mesmo a parcela da 
sociedade que não desenvolve uma visão crítica ou consciência do momento político sentia-se de alguma forma incomodada ou "asfixiada".

\subsection{Esfera policial: o núcleo operário}

Embora a rigidez e a necessidade de ordem sejam características do núcleo falangista, os militantes Lucio e Enrique, representantes do núcleo operário, também expressam as mesmas necessidades. Ambos foram ex-funcionários do metrô, perseguidos políticos, acusados de fazer greves e colocar explosivos em trens. Lucio demonstra sua insatisfação: "Seguramente la necesidad de disciplina militante, el rigor que exigía lo de fuera, lo público, y que acababa ordenando aún a su pesar de dentro, lo privado.” (CHIRBES, 2000, p.147). Para Lucio, o movimento operário também impunha um sistema disciplinar rigoroso, pois a perseguição aos militantes o conduzia a uma vida clandestina. Ele também compartilha o sentimento de asfixia de Guillermo, sente-se tão perseguido que evita falar ao telefone, pois acredita que a polícia colocou grampos. Sobre a militância desse período, vale destacar as palavras de Juan Pablo Fusi (2012, p.235):

Los trabajadores, a cuya movilización contribuiría la aparición a partir de 1960 de nuevos sindicatos clandestinos de oposición, y ante todo de Comisiones Obreras, bajo creciente influencia del Partido Comunista desde 1964, reclamaron libertades sindicales y derecho de huelga.

A reação antifranquista que se manifestou com mais intensidade no final do regime sofreu repressão constante e violenta. Esses fatores conduzem o personagem a rememorar o passado e através desse processo ele transforma a perspectiva que tinha de sua militância. A estrutura do relato organiza-se de modo que o leitor acompanhe a transformação de Lucio através dos desdobramentos temporais. A princípio, ele se considerava um revolucionário que transformaria a Espanha num lugar melhor. No entanto, a perseguição da polícia e as exigências da militância o levaram a uma vida clandestina e marginalizada, transformando-o em um homem solitário e desiludido:

Mientras desde el interior del vagón del metro que lo llevaba a la cita con Lurditas veía pasar los paneles de la estación de Atocha, pensaba en lo absurdo de su vida, él allí, solo, cargado con la pequeña bolsa de deportes como único equipaje, sin saber adónde ir y con la cabeza repleta de sueños de solidaridad desde un montón de años antes [...] (CHIRBES, 2000, p.145). 
Lucio e Enrique são considerados vencidos e esse sentimento de derrota não é atribuído apenas à sociedade, mas também a eles. Esse processo se observa, principalmente, através das rememorações e da representação da consciência de Lucio que está desiludido e sem esperança.

A rememoração do passado é desenhada no enredo por meio da estrutura narrativa, como tempo verbal, léxico, pontuação, representação do fluxo de consciência e mediação do narrador onisciente. O tempo objetivo limita-se ao momento em que Lucio vai ao bar esperar por Lurditas até o caminho que o personagem percorre do bar ao escritório de advocacia de Jesús Taboada. O tempo da subjetividade desenvolve-se quando o personagem rememora sua vida. Este tempo é amplo e engloba recordações de diferentes períodos do passado de Lucio.

Os relatos de Lucio estão divididos em dois capítulos, denominados "nove" e "vinte". No capítulo nove, há apenas um desdobramento temporal e a narrativa tem início com a descrição do operário saindo de uma cabine telefônica, depois de marcar um encontro com Lurditas. Em seguida, o narrador onisciente oferece uma descrição detalhada do trajeto que ele realiza do telefone público até um bar: “... cruzó la calzada para cambiarse de acera y torció por la primera calle a su izquierda: allí se metió en la boca del metro, merodeó por el laberinto de pasillos..." (CHIRBES, 2000, p. 141). A descrição deste caminho é realizada no tempo verbal do pretérito perfeito, o narrador onisciente descreve as ações do personagem com um tom de tensão revelando a sensação de perseguição que o dominava. Na sequência, o tempo verbal utilizado é pretérito imperfeito, para fazer uma descrição detalhada do bar como um local seguro em que eles não seriam vigiados. Além disso, através do espaço do bar o narrador introduz Lurditas, namorada de Lucio:

El bar estaba cerca de la casa de los Ricart, apenas tres o cuatro minutos, y además, en una zona poco concurrida, donde ella podía descubrir enseguida si alguien la vigilaba o no. Lurditas conocía perfectamente las normas de seguridad a las que Lucio tenía que someterse y a las que no le quedaba más remedio que someter a cuantos lo rodeaban (CHIRBES, 2000, p. 142).

Até este ponto toda a narrativa está concentrada no tempo objetivo e na descrição onisciente do contexto de Lucio, ou seja, na tensão que a clandestinidade provoca na ação do personagem, na forma desconfiada como caminha pela rua, nas normas de segurança a que submetia sua mulher e também na escolha cuidadosa dos ambientes que frequentava. Posteriormente há uma mudança no tempo verbal, a mescla entre o pretérito perfeito do indicativo e o pretérito imperfeito indica uma transição do tempo objetivo para o subjetivo. Após descrever o ambiente externo o narrador descreve os pensamentos de Lucio: 
Miró el reloj. Faltaban pocos minutos para las dos. Estaba claro que, para ella, tenía que ser la peor hora para escaparse, puesto que estaría dándole los últimos toques a la comida del mediodía, pero él no quería verla más que un minuto, sólo un minuto, para decirle personalmente lo que no podía decirle por teléfono. La clandestinidad restringía el uso del teléfono. Las líneas telefónicas eran un pasadizo por el que circulaban indeseables visitantes cuyos pasos a veces llegaban a escucharse escoltando las palabras del interlocutor. <<Tiene el teléfono intervenido. Hace unos ruidos raros〉>, se decía entre los camaradas cuando hasta el auricular llegaba eco de esos pasos (CHIRBES, 2000, p.142).

O trecho de transição do tempo objetivo para o tempo subjetivo também é sugerido através da mudança do conteúdo do texto, da repetição dos termos "más que un minuto, sólo un minuto" que possivelmente indicam uma representação direta dos pensamentos de Lucio. Outra característica da transição é a presença de oralidade através do marcador textual " $<<$ " que representa a reconstituição de uma frase que Lucio ouviu. Nos momentos de transição não é possível determinar de forma exata quando se trata de um monólogo ou descrição onisciente. Nos parágrafos seguintes reaparece o tempo subjetivo quando Lucio rememora a sensação de perseguição. Ele suspeitava que o telefone do trabalho de Lurditas estivesse grampeado, pois a polícia o perseguia desde que se tornou membro do Vanguardia Revolucionaria e participou de uma ação para colocar explosivos no metrô. Desse modo, revela-se o momento em que Lucio sentiu-se sozinho pela primeira vez, quando os colegas de trabalho se afastaram desconfiados de seu envolvimento na explosão:

La empresa y hasta los propios compañeros sospechaban que él había tenido algo que ver en las explosiones. En torno a él todo se había ido enrareciendo $y$, en vez de la buscada solidaridad, se extendía la sospecha. Se sentía muy cansado de una forma de vida cada vez más sombría, y más aún aquella mañana. A veces dudaba de sí mismo; de su decisión de empezar a militar en aquél grupo había sido acertada. Por primera vez en su vida, se encontraba solo, condenado a no tener contacto más que con la media docena de militantes con los que concertaba las citas que el aparato del grupo le organizaba $(\ll<$ Vanguardia Revolucionaría no es un partido, es un grupo que trabaja para la reconstrucción del partido del proletariado >> decían los estatutos). Tras su salida de la cárcel había pasado a la clandestinidad [...] Solo y cansado. Vagabundeando de un sitio para otro. Se había sentido especialmente solo aquella mañana cuando comprobó que Enrique y el Viejo no se presentaban a la primera cita de seguridad después de la acción de la noche anterior en la que habían sido sorprendidos por la policía... (CHIRBES, 2000, p.143).

No fragmento citado, a utilização de marcadores textuais, como aspas e parênteses, ressalta que o grupo Vanguardia Revolucionaria representava para Lucio uma forma de atuar em favor do proletariado: "(<< Vanguardia Revolucionaria no es un partido, es un grupo que 
trabaja para la reconstrucción del partido del proletariado〉> decían los estatutos)". Os parênteses apresentam uma interpelação do narrador que se refere com objetividade fria ao que Lucio lia sobre o grupo Vanguardia nos estatutos, ressaltando o sentimento de desilusão com que ele enxerga agora sua militância. De um lado, a descrição onisciente relata o estado interior do personagem, ou seja, seu sentimento de solidão, fracasso e as dúvidas sobre sua escolha de militar por aquele grupo; de outro lado, a interpelação do narrador realiza um contraste entre aquilo que Lucio acreditava ser o real objetivo do grupo.

A recordação dos acontecimentos daquela noite, uma tentativa frustrada de colocar explosivos próximos ao quartel e a perseguição da polícia, introduz os personagens Enrique e El Viejo. Como o tempo subjetivo é flexível e representa o passado em diversos níveis, o enredo desdobra-se temporalmente em um nível mais profundo para narrar a lembrança que Lucio tem da perseguição da noite passada. Esse processo se observa através do uso do tempo verbal do pretérito mais que perfeito composto: “...habían sido sorprendidos por la policía, y tampoco acudieron al segundo contacto, lo que lo convenció de que habían sido detenidos..." (CHIRBES, 2000, p.144).

Narra-se a fuga do grupo até o amanhecer do dia 19 de novembro de 1975 e retorna-se para o tempo presente quando o medo da solidão invade Lucio e ele percebe que não tem para onde fugir: "Pero ¿adónde iba a ir? Estaba lloviznando otra vez y, por el color y densidad de los nubarones, se adivinaba que esa tarde iba a caer una buena tromba de água. ¿Adónde iba a ir?” (CHIRBES, 2000, p. 145). Essa situação o conduz a rememorar a infância e o enredo desdobra-se. Nota-se o uso do pretérito mais que perfeito composto e do pretérito imperfeito:

Hacía unos cuantos años que su padre comía tierra, y él, entre tanto, había conseguido aprender maticería en La Paloma y aprender a leer los libros de Engels, Marx y de Bakunin que les dejaba uno de sus compañeros de su padre, que había abandonado Reinosa huyendo de un pasado de maquis. (CHIRBES, 2000, p.146).

O narrador onisciente acompanha as rememorações de Lucio através do processo de associação de ideias, em que um pensamento conduz a outro. Desse modo, as lembranças de sua infância se dissolvem, ele pensa novamente em Lurditas, tenta compreender porque não desistiu da militância e rememora o passado na cadeia com Jesús Taboada. A estrutura narrativa transforma-se novamente ao introduzir o advogado nas rememorações de Lucio, pois recorre ao uso de diálogos com o tempo verbal no presente do indicativo para presentificar a lembrança. A narrativa ganha densidade temporal, como se Lucio estivesse tão 
compenetrado em seus pensamentos que pudesse reviver ao recordar o tom da voz de Taboada, o que e como foi dito:

'Me hablas del evangelio, compañero - decía Tabo -, todo eso es palabrería clerical. Los curas os han contaminado a los revisionistas, os han prestado su lenguaje, y los revisionistas los usáis creyendo que se trata de un favor que os han hecho' (CHIRBES, 2000, p. 150).

Posteriormente, há um novo momento em que são introduzidos diálogos como forma de intensificar uma lembrança. A lembrança das palavras de Taboada sobre a classe operária faz com que Lucio recorde o dia em que se reuniu com outros companheiros do grupo Vanguardia Revolucionaria para colocar explosivos no trem. A rememoração inicia-se com a descrição e observação do narrador onisciente que recorre aos marcadores textuais, como aspas e travessões, para introduzir uma cena recordada pelo personagem. Em seguida, a recordação de Lucio é descrita como se estivesse no presente, por isso apresenta estrutura de diálogos:

¿Que quieres decir? ¿Qué estás queriendo decir?' 'Que al fin y al cabo, es
un lacayo de ellos.' Ahí fue cuando saltó Lucio, que se acordó de Lurditas:
'Nos cargamos a los porteros, ¿y por qué no a las cocineras? ¿Callamos
también a las cocineras?' 'Tú córtate, no tergiverses las cosas' (CHIRBES,
2000, p. 158).

Lucio participa de um plano para colocar explosivos no trem, juntamente com Enrique, El Viejo e Ezequiel. A ação falhou porque o porteiro flagrou o grupo e gerou uma discussão quando Lucio percebeu que Ezequiel queria matar o porteiro. O operário sentiu-se incomodado com a situação porque se tratava de um homem simples como eles. Além disso, ele percebe que se um homem de classe social desfavorecida, como porteiro, poderia ser alvo das ações do grupo, Lurditas também poderia estar em perigo. Por isso, questiona o amigo sobre o sentimento de culpa:

'No hables de culpa, ni siquiera del error. Esto no es un crucigrama que tienes que rellenar, y que, si te equivocas, borras y empiezas otra vez. Este objetivo del que hablas forma parte de la vida, no está en una lata de conservas, y a la vida no se puede controlar, y, en el camino, pueden pasar muchas cosas, ¿entiendes? En el camino puede quedarse el gordo ese, como podemos quedarnos nosotros, que tenemos menos culpa que él, y, además, tenemos razón.' Lucio se burló: $<<$ La razón histórica $>>$, dijo. Aquello le había sonado a Taboada (CHIRBES, 2000, p.159). 
Ezequiel representa o norte da Espanha, território que teve a independência negada e a identidade cultural silenciada pelo regime ${ }^{14}$. Quando ele revela que para cumprir o objetivo do grupo era necessário aceitar aquilo que não estava nos planos, como matar o porteiro, Lucio apresenta uma postura diferente ao se impor e responde com ironia. Nas conversas com Jesús Taboada na cadeia ele possuía uma visão ingênua dos fatos e recusava a perspectiva que o advogado apresentava sobre a militância e a sociedade. Ele recorda de Taboada referindo-se a razão histórica e contando ao operário que a História era escrita pelos vencedores e, portanto, cabia a eles esta razão: "Lucio se burló: <<La razón histórica〉>, dijo. Aquello le había sonado a Taboada.” (CHIRBES, 2000, p.159)

Além disso, nesse momento vale observar a estrutura da narrativa que começa com um diálogo marcado por travessões, entre Lucio e Ezequiel, e termina com o narrador onisciente descrevendo a cena e utilizando marcadores textuais para representar a fala de Lucio. Trata-se de um trecho de transição entre tempo objetivo e subjetivo. Os diálogos, que representam uma lembrança, são escritos no presente do indicativo e com o uso dos travessões. Essa estratégia indica que se trata de algo tão profundo para o personagem que ele rememora como se estivesse vivendo novamente. À medida que as recordações vão se dissipando, o narrador onisciente assume a narração e termina o relato através de sua perspectiva. Após relembrar o dia em que colocaram uma bomba no metrô, Lucio observa que Taboada não estava presente, embora fosse o idealizador do plano:

[...] y todo por qué, por no haberle dicho a Tabo: $<<$ Qué se vaya todo a la mierda. > Tabo no estaba el día en que tuvieron que amordazar al portero. Mira por donde, dio la casualidad de que no estaba ese día, no señor, pero sí que estuvo una semana después cuando dijó: <<Lo siento. Abandono. A lo mejor es que vuelvo a mi clase. Pero quiero ejercer. He encontrado trabajo en un despacho de abogados y, no sé, me parece que es mi forma de participar en la revolución. Creo en la violencia, pero no sirvo para ejercerla. Seguramente mi mente es más de izquierda que mi sensibilidad. Qué le vamos a hacer > (CHIRBES, 2000, p.160).

Lucio entende a situação com outra perspectiva, pois percebe que Taboada participava do mesmo grupo que ele, mas lutava por objetivos diferentes, assim como Ezequiel. Ele se desespera ao perceber que precisa do advogado para salvar-se, mesmo sabendo que as ações de Taboada variavam de acordo com a conveniência e não por amizade ou consideração:

\footnotetext{
${ }^{14}$ Em resposta a repressão e fragilização da identidade cultural do norte da Espanha fundou-se um grupo terrorista denominado ETA que agia violentamente. Sobre esse assunto destacamos as palavras de Juan Pablo Fusi: "La aparición en 1959 en el País Vasco de ETA, una organización independentista y marxistizante que desde 1968 recurrió al terrorismo como forma de lucha armada por la liberación nacional vasca, rompió la paz de Franco;" (2012, p.236).
} 
“...mientras a través de la puerta acristalada veía a Lurditas avanzar hacia el bar, pensaba que lo necesitaba, que necesitaba a Tabo para lo que fuera, para que lo dejara dormir en el despacho o en algún rincón de su casa." (CHIRBES, 2000, p.161). Embora quase todos os verbos estejam no pretérito imperfeito, essa passagem representa o tempo objetivo, pois Lucio está no bar observando Lurditas entrar.

No capítulo vinte, o tempo objetivo é marcado pelo trajeto de Lucio até o escritório de Jesús Taboada, ele está indeciso entre pedir ajuda ao advogado ou esperar que a polícia o capture. Nesse trajeto ele continua a rememorar seu passado num processo que gradualmente modifica sua perspectiva sobre si. Assim, o tempo subjetivo aflora em quatro momentos diferentes e são realizados quatro desdobramentos temporais, onde se encontram referências a sua companheira Lurditas, Enrique, El Viejo, Jesús Taboada e se introduz o delegado Maximino Arroyo.

No primeiro desdobramento temporal, Lucio rememora os tempos que passou com Taboada na cadeia de Carabanchel, a saída deles da prisão e o rompimento de Taboada com o Vanguardia Revolucionaria. O segundo desdobramento temporal remete ao tempo futuro, Lucio imagina como iria ser recebido se batesse na porta do escritório de Taboada. No terceiro momento, o operário rememora o violento interrogatório de Maximino e por fim desiste de pedir ajuda ao advogado, pois conclui que "...era absurdo pedirle a Taboada algo que él mismo le enseñó que había que arrancar a punta de fusil.” (CHIRBES, 2000, p.316). Para Jesús Taboada eram necessárias armas para fazer a revolução, mas Lucio frustra-se ao perceber que suas armas limitavam-se aos seus pertences pessoais: "Sus armas. La bolsa colgada del hombro con la muda y los útiles de afeitar, y, en el bolsillo de la chaquetilla, la cartera gastada..." (CHIRBES, 2000,p. 317).

Esse momento é o ápice da transformação do personagem, além disso, ele reconhece que não poderia pedir ao Vanguardia Revolucionaria aquilo que lhe ensinaram que só poderia ser adquirido através da violência: " $<<$ Los revisionistas creen en la piedad, en la compasión, en que lo justo llega por sus proprios pasos, por una necesidad razonable. Los revolucionarios sabemos que no es así. El poder está en la punta del fusil.>> (CHIRBES, 2000, p. 317). O ato de rememorar sua história pessoal permite que Lucio apresente sua perspectiva sobre uma sociedade que o considera marginalizado e também o leva a transformar seu modo de enxergar o mundo, pois ele vê criticamente sua militância no grupo Vanguardia Revolucionaria. 
O relato de Lucio é marcado pelas ações da consciência e não do corpo, visto que em seu relato há uma densa atividade interior capturada no tempo subjetivo. O processo inverso ocorre com Enrique cujo relato é marcado pelas ações do corpo, da adversidade e da violência física. Sua narrativa está composta pelos capítulos “dois" e "quinze”. No capítulo dois relatase a fuga do personagem e o capítulo quinze aborda sua estada na prisão. As adversidades que ele encontra durante a perseguição e após a captura, como o cansaço, a dor, o frio e o medo, resultam em uma dificuldade de articular o pensamento que é reproduzida na representação de sua consciência. As impressões do personagem sobre o ambiente ao redor são adquiridas, de modo fragmentário, através de quatro sentidos: olfato, audição, tato e paladar. Portanto, a estrutura do relato e a tensão narrativa se estabelecem através do registro da percepção dos sentidos.

No caso de Enrique, nesse trecho, há uma mescla entre o tempo subjetivo e objetivo, indicando que sua consciência relaciona-se mais com as sensações do presente do que com a rememoração do passado. O tempo objetivo tem inicio com o nascer do dia, quando Enrique foge da polícia, e se estende até o período da tarde, quando ele é preso. O tempo da subjetividade destina-se à descrição das sensações do personagem enquanto ele foge e quando está na prisão.

O enredo do capítulo dois oscila constantemente entre o tempo objetivo e o subjetivo; essa mescla atua no ritmo narrativo, que ora desenvolve-se com velocidade e ora de modo vagaroso. No tempo objetivo narra-se a perseguição e no tempo subjetivo representa-se a consciência do personagem, aquilo que ele sente e pensa enquanto corre. Esse capítulo iniciase com uma apresentação onisciente no tempo subjetivo, marcado pelo uso de verbos no pretérito imperfeito e no pretérito mais que perfeito composto para contar a angústia de Enrique que se recusa a aceitar que o tiro disparado durante a noite poderia ter matado seus companheiros:

Habían disparado. Aquello había sido un disparo. Había oído el ruido al mismo tiempo seco y atronador de un disparo. Luego oyó pasos que se perdían en distintas direcciones y otros que parecían contrapuntear los suyos detrás. También un golpe sobre la hierba que podía ser un cuerpo a desplomarse. Pero no, no podía ser un cuerpo, tenía que ser otra cosa (CHIRBES, 2000, p. 27).

A tensão narrativa se estabelece através da contraposição entre o sentido da audição e da visão, pois o relato tem início com o barulho de um tiro. Enrique deseja virar-se para ver o que aconteceu, mas não pode parar de correr, portanto apenas escuta e supõe. A princípio o narrador aproxima-se da consciência de Enrique e depois se afasta. Esse movimento torna-se 
visível por meio de alterações no conteúdo e na sintaxe do texto. No momento em que se aproxima da consciência nota-se a repetição de expressões e o uso de frases curtas, assim como a sensação de dúvidas em relação aos fatos: "Habían disparado. Aquello había sido un disparo. Había oído el ruído al mismo tiempo seco y atronador de un disparo". O distanciamento que o narrador estabelece em relação à consciência do personagem é marcado pela apresentação de conteúdos organizados, informativos, descritivos e detalhados do espaço narrativo. Uma descrição da perspectiva de Enrique que corre amedrontado não poderia ter informações tão precisas e detalhadas do espaço e do clima:

Aquel otoño aún no había llovido y todo estaba seco, polvoriento. No había caído ni una gota en todo el verano, ni una tormenta, nada. Los hierbajos secos y endurecidos por las heladas, la grama; cuyas inflorescencias se quedaban prendidas del calcetín y se dejaban notar desgraciadamente a cada paso, los cardos, que herían las pantorrillas con sus hojas espinosas a las que el precipitado movimiento de las piernas hacía actuar como afiladas cuchillas que dejaban rasguños sobre la piel por encima del límite de los calcetines. No, ahora, no se oía nada aparte de sus propios pies pisando la maleza seca, y sus propios jadeos, y el ruido de su propia ropa rozándose por el movimiento. Olía a polvo. Ni siquiera la madrugada conseguía impregnarle un poco de humedad al aire. Dentro de un rato iba a amanecer, y de hecho ya se veía un reborde de claridad por encima de las edificaciones... (CHIRBES, 2000, p. 27-28).

Como se observa no fragmento, o narrador aproxima-se novamente da perspectiva de Enrique quando surgem as marcas de oralidade como "ahora", a repetição do termo "no" e a descrição do ambiente a partir dos sentidos. Além disso, as interpelações do narrador marcadas através dos parênteses indicam certa afinidade com o personagem, pois ele compartilha suas dúvidas e angústias: “(¿estaba alguién aún ahí, a sus espaldas?, ¿corría alguien todavía detrás de él?)" (CHIRBES, 2000, p. 28), "(¿jadeos del Viejo?, ¿de Lucio?)" (CHIRBES, 2000, p.28), “(¿Se había iluminado la noche?, ¿o el fogonazo sólo había estallado en su cerebro?)" (CHIRBES, 2000, p.31) e “(¿dónde era?: un patio, un pasillo de color verde)" (CHIRBES, 2000, p.31)".

Nota-se que a perspectiva de Enrique é sempre acompanhada da representação dos sentidos, pois é através deles que o personagem lê o mundo naquele momento. O uso do verbo "olía" remete ao olfato e através desse sentido revela-se o espaço narrativo; trata-se de um lixão. Pode-se deduzir que a perseguição se estende até a periferia da cidade: "Olía a descomposición, a naranjas podridas, a aceite de motor, a metales oxidados" (CHIRBES, 2000, p.30). Ao tato se deve o uso dos termos "cardos que herian", "hojas espinosas", "afiladas cuchillas", "rasguños sobre la piel", que complementam as informações sobre o 
espaço narrativo. As impressões visuais de Enrique marcam temporalmente a narrativa, pois sugerem as horas: "Dentro de un rato iba a amanecer, y de hecho ya se veía un reborde de claridad por encima de las edificaciones..." (CHIRBES, 2000, p.28). O verbo "oía” remete à audição e acentua a tensão narrativa, pois os sons indicam a direção e a velocidade com que ele corre. Sua captura se deve a uma falha na sua audição, pois ao perceber um ambiente silencioso interrompe a fuga: "Notó el silencio a su alrededor ...Se detuvo junto a la tapia, volvió la vista." (CHIRBES, 2000, p.30).

A princípio, o relato configura-se no nível da descrição onisciente quando, Enrique temendo por seu futuro, faz suposições quanto ao que poderia acontecer-lhe e a narrativa transita para outro nível da subjetividade. A transição de nível discursivo é marcada pelos verbos no futuro do pretérito do indicativo e pretérito imperfeito do subjuntivo:

\begin{abstract}
Pensaba como sería_la noche con las rozaduras escociéndose en las rodillas, con el dolor de un esguince, de una rotura ardiéndole en el tobillo, una punta de hierro atravesándole el pie. Cómo sería ver el barrio desde el suelo [...] Ese era el miedo menor, pero también inmenso: tener que arrastrarse a duras penas, ayudándose de codos y pies, por aquella superficie irregular que percibía bajo las suelas de los zapatos en su carrera, y que hacía tan difícil la marcha [...] No, que no le pasara nada, que no se torciera un tobillo, no se hiciera un esguince, no se rompiera un pie. El otro miedo, el grande, era el que, al parecer se iba quedando detrás, el que ya era imposible percibir pero que seguía estando detrás (CHIRBES, 2000, p. 29-30).
\end{abstract}

Na sequência, a polícia captura Enrique e a narrativa retoma o nível da descrição da onisciência e depois realiza um desdobramento temporal para o tempo objetivo que se encontra com o tempo subjetivo. Essa mescla de níveis narrativos tem a finalidade de apresentar o momento da captura a partir da perspectiva de Enrique e, na sequência, retomar esse mesmo momento a partir da perspectiva do narrador.

O narrador aproxima-se da consciência de Enrique para retratar o momento do golpe na boca e da queda a partir da perspectiva do personagem. Desse modo a narrativa retoma o nível da descrição onisciente: “¿Dónde? El metal, sentir que una nueva explosión te atrae hasta el suelo, o que se desploma sobre ti una de aquellas sombras negras y sientes el dolor del metal en la boca." (CHIRBES, 2000, p.30). A aproximação do narrador está explícita quando questiona “¿Dónde?” e no uso de verbos no presente do indicativo, como “atrae”, "desploma” e "sientes" para narrar sensações relacionadas aos sentidos, como a dor. Além disso, o tempo verbal no presente permite que o leitor também se surpreenda com a cena, como se estivesse no lugar do personagem. 
Retoma-se a cena de modo detalhado e sua composição ocorre a partir da perspectiva do narrador. Desse modo há um desdobramento temporal para o tempo objetivo, representado textualmente pelo verbo "notó", no pretérito perfeito. Vale ressaltar que esse desdobramento não ocorre por completo porque as oscilações para o tempo subjetivo são constantes. A mescla entre os níveis temporais se estabelece através dos tempos verbais no pretérito perfeito e pretérito imperfeito com a finalidade de narrar a cena com maior precisão:

Notó el silencio a su alrededor, un silencio envuelto por el lejano rumor del tráfico y, de repente, se le evaporó el miedo y le pareció que ya no tenía sentido seguir corriendo. Se detuvo junto a la tapia, volvió la vista [...] cuando se dio cuenta de que sobre la sierra flotaba una masa negra que iba abriéndose como un abanico por encima de los picos, una mano pegajosa y decidida; $y$, justo en ese momento, mientras contemplaba la lejana formación de nubes que saltaban por encima de los montes, y le parecía escuchar el redoble de un trueno, sintió que algo se le venía encima, y escuchó voces al tiempo que se derrumbaba bajo un peso enorme. Dolor en la cabeza, en el pecho, en las canillas, en los tobillos. Y voces. Estaban pisoteándolo. Le daban patadas, lo levantaban con el pie, caía de nuevo y recibía otra vez las patadas. Cuando lo subieron al coche, le pareció que sonaba otro trueno en la lejanía, pero eso lo pensó en algún lugar muy remoto de su cerebro, y no se le ocurrió volver a mirar las nubes, si habían continuado su avance y cubrían ya una parte notable del cielo, no se lo ocurrió mirar nada, ni siquiera los rasguños y moretones de su piel (CHIRBES, 2000, p.30-31).

O pretérito imperfeito indica o momento da captura como se a cena fosse observada à distancia pelo narrador. Além disso, os verbos "daba", "levantaba", "caía", "recebia", "saltaba", "venía" e "daban" remetem às pancadas recebidas pelo personagem. O pretérito perfeito apresenta novas ações e acelera aquelas já enumeradas, fazendo com que a narrativa avance. O narrador retoma e relata detalhadamente o golpe, a queda e as sensações de Enrique. A combinação entre o pretérito imperfeito e pretérito perfeito auxilia na narração detalhada e confere à cena um efeito de câmera lenta.

A princípio as frases são bem articuladas e mais longas, pois o silêncio conduz Enrique a supor que não há mais perigo. Como se observa no trecho citado, a agitação do personagem se desvanece em uma calmaria ilusória: "Se detuvo junto a uma tapia, volvió la vista. Todo parecía tranquilo a sus espaldas [...] No hacía nada de viento, todo estaba en calma [...]" (CHIRBES, 2000, p.30). No entanto, o ritmo altera-se novamente acompanhando a mudança climática da narrativa, pois as nuvens escurecem o céu e quando começa a chover a polícia franquista encontra Enrique.

Além dos tempos verbais, a estrutura do texto, como o uso de frases curtas, a pontuação, o léxico e a semântica induzem um ritmo de leitura que sugere a respiração acelerada do 
personagem: "Dolor en la cabeza, en el pecho, en las canillas, en los tobillos. Y voces. Estaban pisoteándolo. Le daban patadas, lo levantaban con el pie, caía de nuevo y recebía otra vez las patadas.”( CHIRBES, 2000, p.30-31). O narrador reflete sobre os sentidos de Enrique: "Era como si sus sensaciones y pensamientos formaran parte de un complejo sistema retráctil y reversible y se ocuparan sólo de su interior" (CHIRBES, 2000, p.31). A chuva funciona como estímulo sensorial para que ele retorne à consciência: "Y, en eso momento, al notar el impacto de las gotas cayendole encima, fue cuando, a pesar del cansacio y del dolor, encontró fuerzas para pensar." (CHIRBES, 2000, p.31).

O narrador aproxima-se novamente da perspectiva de Enrique, apropriando-se do modo de pensar e falar do personagem que recorda um ditado: "Pensó, entre otras cosas, en qué deprisa y de qué modo tan impresible cambiaban las circunstancias. El hombre propone y Dios dispone." (CHIRBES, 2000, p.31). Num primeiro momento, a voz narrativa parece pertencer ao narrador, pois o uso do verbo "pensó" sinaliza um narrador que descreve a sensação de cansaço e o pessimismo do personagem capturado. Contudo, outros trechos do relato de Enrique revelam que o ditado leva-o a constatar sua relação com Deus, movimento que não é do narrador: "Dios. Ya se le había cruzado la idea de Dios tres o cuatro veces en su pensamiento aquella mañana." (CHIRBES, 2000, p. 239).

O capítulo dois termina com uma indagação do narrador: “¿Adónde lo habían llevado?” (CHIRBES, 2000, p.32). Este questionamento desenvolve a tensão narrativa do capítulo quinze, pois Enrique encontra-se preso em um lugar desconhecido e tenta inutilmente localizar-se por meio dos sons do lado de fora. Desse modo, seu fluxo de pensamentos introduz o tempo subjetivo. Assim como no capítulo dois, o capítulo quinze tem início com o tempo subjetivo e há uma mescla contínua com o tempo objetivo que se estende até o final da narrativa:

Estaba lloviendo. Desde aquella habitación, o celda, porque tenía unas rejas en la ventana que estaba situada allá arriba, en la parte dónde el techo ascendía más, oía caer la lluvia e incluso alcanzaba a distinguir, lejanas, voces de gente que pasaba por la calle (¿ qué calle sería aquella? Sólo había visto el patio, habían metido el coche hasta dentro el patio) (CHIRBES, 2000, p. 238).

Como se observa no fragmento, a primeira cena é descrita pelo narrador onisciente que recorre ao pretérito imperfeito e pretérito mais que perfeito composto. Na sequência, Lucio é introduzido na narrativa através dos marcadores textuais, pois Enrique rememora um diálogo entre eles. O uso de marcadores textuais " $<<$ " e dos verbos no presente do indicativo, como 
"da", "es" e "va", ressaltam o desdobramento para outro nível discursivo do tempo subjetivo, o nível da rememoração:

$<<$ Tranquilamente, con sus problemas, con lo que quieras, pero caminando por la calle la gente >, pensó Enrique Roda con envidia. Ahora volvía a llover, porque se oía el ruido del agua allá arriba y hasta había algunas gotas que se colaban en el interior. <<También es casualidad que, después de tantos meses, se haya puesto a llover hoy. ¿Será verdad que es un enviado de Dios? >><<ios es franquista, que no te quepa duda >>, le decía Lucio a él en broma. $\ll<$ ¿Será verdad que se ha muerto, y que el cielo está llorando por él? Ojalá. En ese caso, bienvenida sea el agua, aunque me da la impresión de que esto va a ser muy húmedo y a mí no es que me siente mal la humedad, que también es que la odio. No creo que me tengan aquí mucho tiempo, me mandarán al juez, pero ¿dónde estoy? Aquí no he visto guardias, nada, el patio y el pasillo. (CHIRBES, 2000, p.238).

O sentido que predomina no capítulo quinze é o tato, pois chove e o personagem incomoda-se com a humidade do local: "y a mí no es que me siente mal la humedad, que también es que la odio" (CHIRBES, 2000, p.238). Visto que a humidade está relacionada com um léxico pessimista, o personagem a utiliza como uma referência ao ditador Franco, pois ironicamente sugere que “...el cielo está llorando por él...” (CHIRBES, 2000, p.238). Além disso, as sensações provocadas pelo ambiente húmido conduzem Enrique a rememorar o passado no orfanato ${ }^{15}$ :

Oía caer la lluvia, y se acordaba del patio, pero no del patio que le habían hecho cruzar esa mañana para llegar hasta allí, sino del que formó parte de su infancia. Las noches de lluvia en que lo castigaban a dar vueltas por el patio durante horas. Los días de frio en que tenían que aguantar allí, formando largas filas bajo la tormenta de nieve, que se endurecía alrededor de sus zapatos (CHIRBES, 2000, p.239).

No trecho citado, a perspectiva volta para o narrador onisciente que finaliza o relato com uma frase e retoma o sentido da audição ao ressaltar o silêncio: "Todo estaba en silencio." (CHIRBES, 2000, p. 241). Realçar os sentidos de Enrique também é uma estratégia para representar a fuga a partir de sua perspectiva, ou seja, de seus pensamentos pouco

\footnotetext{
${ }^{15}$ A humidade descrita nas lembranças do personagem Enrique Rodas remetem às experiências de Rafael Chirbes que também passou a infância em um orfanato. No artigo "La narrativa de Rafael Chirbes, entre las sombras de la historia", Fernando Valls comenta que alguns aspectos da vida do escritor são representados por meio dos personagens: "Cuando Rafael contaba con solo 8 años lo enviaron a estudiar en un colegio de huérfanos de ferroviarios, primero Ávila y luego León, como le ocurre a Rafael de Moral, el personaje de La larga marcha. Después, estuvo interno en Salamanca, donde sus compañeros solían ser hijos de la burguesía local, rompiendo con la igualdad que imperaba en las anteriores instituciones escolares. El radical cambio de paisaje y clima, el frío seco de Ávila y el húmedo de León, y la separación de su familia le resultó en parte trágico pero también excitante, como él mismo ha explicado.” (2015, p.128).
} 
articulados e desesperados. Desse modo, se estabelece uma contraposição com a primeira frase do capítulo: "Había disparado" (CHIRBES, 2000, p. 41). Esta frase remete ao final trágico do personagem que será anunciado nos relatos de Maximino Arroyo, quando este ordena que seus policiais assassinem o preso: "Se las había dado esa tarde, cuando el comisario Arroyo volvió de comer con un par de copas de más y los llamó a Leonardo y a él a su despacho, y les dijó: <<El preso no existe.>>" (CHIRBES, 2000, p.271).

Como se observa na análise, a repressão foi um dos elementos fundamentais para a sustentação do regime, garantindo sua duração e sustentando a ideia estabelecida durante a Guerra Civil de que a sociedade estava dividida entre vencedores e vencidos. Mas, no romance, mesmo aqueles considerados vencedores, como Maximino e Guillermo, revelam sentir pânico frente à possibilidade de mudanças no regime, pois isso os fragilizava. Maximino vivencia relacionamentos fracassados com Carmem e Lina e teme a morte de Franco, pois perderá seu poder. Guillermo sente-se um perdedor por assassinar Enrique, pois teme que no futuro possa estar no lugar de sua presa. Enrique e Lucio, por sua vez, além de serem considerados vencidos, sentem-se fracassados e cansados de uma vida de repressão e clandestinidade. 


\section{CAPÍTULO III \\ A repressão civil}

\subsection{Esfera privada}

Um olhar sobre a narrativa revela que o controle social não se limita à violência física e aos conflitos entre a polícia e militantes, mas reflete-se na sociedade civil, atuando como uma força que se manifesta em outras esferas da vida social. A análise da esfera privada apresenta como o controle era exercido de modo camuflado nos ambientes privados e, principalmente, nas relações familiares.

A família Ricart representa o topo da hierarquia social e ocupa o núcleo central do romance. Todos os personagens estão ligados a José Ricart, um empresário que quando jovem lutou na Guerra Civil ao lado dos republicanos, mas para ficar do lado vitorioso abandonou seus companheiros e tornou-se um falangista. Sua esposa, Amélia Ricart, está definhando devido à doença de Alzheimer. Tomás é o único herdeiro de José e trabalha como economista na empresa familiar. Trata-se de um homem prático, mas incapaz de compreender que se aproxima uma complexa mudança política. Quini é o neto caçula, um jovem com uma utopia social, estuda História na universidade para tentar compreender o mundo ao seu redor e fugir da possibilidade de trabalhar na empresa da família, repetindo a história de seu pai e avó.

Como um contraponto a Quini, está Josemari, o filho mais velho, um jovem nervoso e agressivo que é falangista e acredita na violência como solução para a situação política da Espanha. Ele ocupa pouquíssimo espaço na narração e é caracterizado por vozes de outros personagens. Olga, a esposa de Tomás e mãe de Quini e Josemari, é a única da família que está empolgada com a festa de aniversário e organiza-a cuidando de cada detalhe. Trata-se de uma mulher exigente e mimada que leva uma vida luxuosa.

José, Tomás e Quini representam três gerações da família Ricart e seus conflitos. Eles são construídos como personagens de seu tempo e estão relacionados aos momentos históricos da Espanha, como a Guerra Civil (José), o franquismo (Tomás) e a contestação do regime (Quini). A mobilidade de perspectivas ressalta o contraste entre os pontos de vista dos personagens, permitindo a reconstrução da memória social a partir da individualidade de cada um. Para tanto, a personalidade de José evidencia-se diante daquilo que Tomás narra sobre ele 
em suas lembranças, assim como a personalidade e história de Tomás são construídos a partir do contraponto entre as vivências e recordações que tem do pai e de si. A imagem dos Ricart é formada através dos fragmentos de relatos de seus membros e de outros personagens. A perspectiva de José apresenta um panorama pessimista sobre a família:

Y de un modo convergente la vanidad de Olga, cada vez más snob, caprichosa y exigente; su hijo Tomás, encerrándose en un especie de autismo, dedicado a la administración de la empresa, y negándose a trazar proyectos fuera del cotidiano mundo que se desvanecía; las discusiones de sus nietos en torno a la mesa del comedor; Quini, listo y altivo, Josemari, servil y violento; y sobre todo, como si ella sola expresara todo, la enfermedad de su mujer. Su progresiva huida de cuanto ocurría fuera de casa al principio; de la propia familia más tarde; de si misma, al final. Amélia. ¿Qué escuchaba Amelia?, ¿adónde se había marchado? Cuando Tomás y Olga se empeñaron en celebrar su setenta y cinco aniversario $(<<$ Setenta y cinco años, papá. Las bodas de platino con la vida 〉>, había dicho la cursi de su nuera), él se había negado una y otra vez a celebrar nada. ¿Celebrar?, ¿qué? ¿Qué hacía meses que Amelia paseaba por la casa a ratos como un fantasma, a ratos como un niño y, otros, la mayoría, como un mascarón que precediera al velero de la muerte? (CHIRBES, 2000, p.17).

Para José a família é como uma peça de uma máquina com a função de favorecer o desenvolvimento econômico de seus negócios. No entanto, ele perde o controle sobre os membros da família quando nota que o contexto político reflete-se nela. Desse modo, os Ricart representam um sistema patriarcal em crise. Cresce a ânsia de emancipação e o desejo de independência dos netos que buscam uma identidade como geração, com ideias próprias. Os caprichos de Olga, como a festa de aniversário, incomodam José. Assim como os convidados, ele não deseja participar do evento. O narrador compartilha da opinião de José sobre Olga para ressaltar a insistência dela em realizar uma festa mesmo que ninguém estivesse disposto a comemorar. Através das marcações em parênteses ele interpela o leitor com observações e se refere a Olga como "cursi ”.

Tomás acredita que seu pai casou-se com sua mãe por interesse financeiro, pois ela era herdeira de grande fortuna e seria um investimento para seus negócios: "Había puesto el insecto las patas sobre la muchacha de la calle de La Paz de Valencia, la inconsciente heredera de huertos y de una empresa exportadora del Grao..." (CHIRBES, 2000, p. 218). Ele se refere ao pai como um inseto que sugou a vida de Amélia. Em sua perspectiva, o pai representa a imposição da ordem, pois ele assume a função determinada por José, anulando seus sentimentos e personalidade num processo de autocensura:

$<<$ Este año se irá Olga sola a la playa, yo prefiero quedarme aquí, porque quiero adelantar el fichero>>, chaqueta negra, Madrid, las tardes en El Escorial, con Elisa, la cocinera, y Roberto, el chofer; con su padre, con los 
amigos de su padre; y, por las noches, las llamadas telefónicas de Olga desde San Sebastián, o desde Jávea: $<<$ No te creas, este año no ha venido mucha gente, los niños en la gloria, disfrutando como locos del agua $>$, ella invitándolos a saltar desde la roca y esperándolos con la sonrisa - menos franca que la de su madre-, con los pechos bronceados, y él acudiendo a verlos algunos fines de semana, y sus hijos, Quini y Josemari, seguramente pensando que su padre es un insecto negro, con un caparazón de queratina debajo del cuál se arrastra algo viscoso y blando, y equivocándose, equivocándose de medio a medio porque qué hay debajo de su caparazón, que hay debajo de Tomás Ricart Viñal, nada, nada, debajo no hay nada, él nunca ha tenido muchachas a las que echan el trabajo, ni Pidoux, ni las Palmeras, ni Morocco, él no tiene nada debajo de su caparazón negro, nada, una oquedad, un vacío. Seguir el camino que alguien trazó para él. Él había sido el hueco que dejaba el molde de su padre. $<<$ ¿Quién eres? $>>$, le pareció escuchar la voz de su madre. $<<$ ¿Y tú quién eres?〉> La voz de la mujer sonaba ronca, sofocada, pero era como una mano extendida de ciego, palpando el camino que tenía por delante, era su propia voz que se le había escapado entre los labios sin querer, su voz que no sabía muy bien si le preguntaba a Tomás Ricart Viñal, o a su madre: $<<$ ¿Quién soy?, ¿y yo quién soy?>> (CHIRBES, 2000, p. 217).

Tomás constrói uma perspectiva de sua família a partir daquilo que ele acredita que os filhos pensam dele e do contraste entre ele e José e entre Olga e Amélia. Ele repete o comportamento do pai mesmo consciente de que isso afeta sua relação com os filhos do mesmo modo que afetou a relação entre José e ele. Ele considera Olga uma mulher superficial quando revela que o vinculo entre ela e as crianças não era tão sincero quanto o vínculo entre ele e sua mãe: “esperándolos con la sonrisa - menos franca que la de su madre-...”. A consciência de Tomás é apresentada por um monólogo, evidenciado pela pontuação escassa, repetição de palavras, cortes de enunciado e uma sintaxe não convencional, composta através do acúmulo de enunciados. O trecho selecionado retrata a essência da vida de Tomás, ou seja, o único espaço em que ele conserva algum tipo de expressão: o profissional e o doméstico.

Seu espaço profissional é representado pela sequência aparentemente desconexa dos substantivos que compõem a associação de ideias com o seguinte fluxo: paletó preto- MadridEl Escorial- Elisa cozinheira - Roberto chofer - pai. No espaço doméstico há referências à sua casa de férias, esposa e filhos: Javea- Olga - Quini e Josemari. Em um jogo de associação de ideias ele se compara como algo vazio: "él no tiene nada debajo de su caparazón negro, nada, una oquedad, un vacío. A repetição das palavras "nada" e "equivocándose" também ressaltam essa ideia de vazio que ele constrói de si”.

Para representar o fluxo de consciência a pontuação é escassa, composta apenas de vírgulas utilizadas de modo não convencional e, dessa forma, imprimindo um ritmo acelerado à narrativa. A sensação de velocidade das ideias transmite a sensação de contato direto com a 
consciência de Tomás, ressaltando o uso do monólogo. O ponto final só aparece quando o narrador onisciente ganha voz, concedendo uma pausa na velocidade de leitura e coerência sintática à narrativa.

Isso ocorre porque o narrador onisciente interrompe o monólogo interior e desdobra o tempo, pois transporta o personagem para o tempo presente. No desdobramento objetivo do tempo e espaço, Tomás está no quarto observando a mãe dormir, ela está em estado febril e em sua alucinação lança um questionamento ao filho: “¿Quién eres?”. Nesse momento, a voz de Tomás mescla-se à de sua mãe e nesse jogo de vozes o autor da pergunta torna-se ambíguo: “¿y yo quién soy?”. Pela primeira vez, o questionamento de Tomás é empregado no tempo presente remetendo aos questionamentos de seu filho Quini que, em contrapartida, busca respostas no tempo futuro. O jovem representa as expectativas do período final do regime:

Cuatro o cinco piedras, había tirado cuatro o cinco piedras y había corrido confundido en el grupo de estudiantes, y había vuelto a querer ser otro, otro día más jugando a ser otro, pero quién, quién quería ser él, a ver, explíquenoslo, quién demonio quiere ser usted, joven Ricart. No el gerente de Ricartmoble, o sea, que eso no, no el socio del imbécil de su hermano que entra por la noche en la habitación en calzoncillos a pedirle un cigarro, pierna de animal, de mamífero cargado de futuro, el vello del pecho, las narices romas y anchas, el cuello también romo y ancho y el cerebro romo y estrecho, si existente; los dos socios, los felices hermanos Ricart, hablando de negocios, encendiendo un cohíbas uno al otro, cruzando las piernas, los muslos de hipopótamo de su hermano Josemari, hablando de inventarios, de reparto de beneficios, y echando humo por las narices, por la boca, o, como les hacía ver su padre cuándo eran más pequeños, echando humo por los ojos, por las orejas: << ¿quieres ver cómo hecho humo por los ojos?>>, y él embelesado, nervioso, pidiéndole que le deje el puro: $<<$ yo también quiero, papá, yo también quiero.〉> Josemari y él: 〈<Yo también quiero〉>, y el mundo en el mapa: simas marinas de intenso color azul cobalto, plataformas litorales de suave azul cielo, llanuras verdes, montañas de un marrón intenso y que terminan con una macha blanca, España amarilla, Francia verde, Italia rosa, la URSS también de color rosa, pero más clara y grande y lejana, y su hermano y él ante la mesa, y el abuelo encendiendo el cohíbas, sacando la mano del ataúd para encender un cohíbas, y la abuela que se ha quitado los pañales y embadurna de mierda el espejo del baño otra vez... (CHIRBES, 2000, p. 283)

Quini foge de um protesto organizado pelo movimento estudantil. Após jogar algumas pedras contra a polícia abandona seus amigos, refugia-se em um bar, acaba embriagado, pois sente vergonha de sua covardia. Como se observa no fragmento acima, em que se representa o conflito existencial de Quini, a perspectiva dos personagens ora é revelada pelo narrador onisciente e ora através do monólogo interior. O trecho citado tem início com o discurso do 
narrador onisciente que acompanha a consciência embriagada de Quini. A presença do narrador é marcada pela expressão " $a$ ver" que propõe uma organização na estrutura da sintaxe, revelando uma construção articulada, diferente de um monólogo, e através da expressão "explíquenoslo", com a qual o narrador se dirige diretamente a Quini. As interpelações do narrador em relação a Quini indicam sua falta de afinidade com o personagem. Em algumas ocasiões, ele é irônico e impaciente com Quini ao apontar suas dúvidas existenciais e a multiplicidade de "outros" que habitam o jovem.

Representar a consciência na textura narrativa é uma forma de revelar várias faces que o narrador e os personagens podem assumir. Esse tipo de efeito concede intensidade à narrativa, pois pode causar variações no distanciamento entre personagem e narrador. Esse afastamento depende do grau de afinidade ou interesse pessoal que o narrador tem em relação ao personagem. O narrador compartilha a falta de afinidade de Quini pelo o irmão mais velho, Josemari, bem como das observações irônicas: "imbécil de su hermano" e "el cerebro romo y estrecho, si existente;"'.

As preocupações de Quini referem-se ao futuro. Em sua consciência o avô José é representado simbolicamente no caixão como uma alusão ao destino do general Francisco Franco e do próprio franquismo: "el abuelo encendiendo el cohíbas, sacando la mano del ataúd para encender un cohíbas". As imagens metafóricas da mente embriagada de Quini o sufocam, assim como seus pensamentos, pois ele não consegue articular e expressar todas as suas angústias. A imagem elaborada por Quini sobre a família é revelada sob a perspectiva de Juan Bartos, pois o professor rememora o momento em que Quini o convida para a festa de aniversário de José Ricart e tece comentários sobre os Ricart:

A Juan Bartos no le hacía ninguna gracia aquella visita descabellada, y
menos aún cuando Quini le había descrito esa mañana a los asistentes: un
viejo supuestamente liberal, que cumplía tres cuartos de siglo, un par de
amigos del homenajeado (<<muy fachas, yá verás >>, había puntualizado
Quini), un nieto revolucionario (el proprio Quini), otro medio nazi, una
madre que adoraba el arte, y un padre al parecer casi inexistente. (CHIRBES,
2000, p. 185).

Nota-se que a personalidade de Quini é representada em contraste com irmão Josemari, um jovem alienado que acredita na violência como meio para estabelecer a ordem. Tomás compartilha a opinião de Quini e de José em relação ao comportamento de Josemari: "Pensó que en eso sí que tenía razón el viejo Ricart: Josemari no se enteraba de nada. No se había enterado ni siquiera de quién era quién en la familia." (CHIRBES, 2000, p.168). Durante uma 
discussão com Tomás, Josemari apresenta sua perspectiva sobre a família Ricart e confirma os relatos sobre sua personalidade difícil:

Cuando el padre ya no sabe dónde está la frontera entre el bien y el mal, pierde su autoridad. Y entre la familia y la patria tengo que elegir por fuerza a la patria, que es la que da sentido a la familia en la que el padre no sé si es débil o cobarde, y el hermano es traidor, cómplice de asesinos. Me toca elegir a la patria frente a la familia (CHIRBES, 2000, p.169).

As palavras de Josemari aludem ao modo como o franquismo exercia o controle em ambientes privados, como o lar. O jovem exalta a pátria e tende a hierarquizar as relações, inclusive as familiares. O sistema de hierarquia é rompido apenas quando o pai se nega a compartilhar suas opiniões. Além disso, Josemari retoma a imagem que Quini, José e o próprio Tomás constrói de si. Tomás é descrito pelos filhos como alguém sem individualidade e autoridade. Vale ressaltar que José inibe a individualidade do filho transformando-o em mais uma de suas peças de desenvolvimento econômico. E Tomás, apesar de reprovar as atitudes do pai, repete as ações e o modelo imposto. Essa atitude sugere uma metonímia para sua geração, pois durante a ditadura franquista, a individualidade e a reflexão não eram assuntos em pauta.

Quini representa as expectativas sobre o futuro e por isso sofre com sua busca angustiante por respostas. Porém, para descobrir quem são seu avô e pai, o jovem precisa conhecer a origem da família, da fortuna e do papel que cada um desempenha. José deixou lacunas na história da família após a Guerra Civil, pois não relatou suas vivências e iniciou um processo de silenciamento que desencadeou em seus herdeiros um conflito existencial. Seu passado não era comunicável a suas futuras gerações porque eram desmoralizantes. No entanto, transformar seu passado em uma lacuna misteriosa é como apagar o período histórico em que viveu.

Tomás não tem acesso ao passado e origem de José, portanto, também desconhece a história da Guerra Civil e da primeira década do pós- guerra. Isso se reflete em sua dificuldade de relacionar-se com os filhos, de compreender o presente e perceber que a morte de Franco pressupõe mudanças: “...Quini no lo llamaba cobarde, sino intolerante, y no, los intolerantes eran ellos, sus hijos, que no toleraban la vida en su discurrir, que querían cambiar por la fuerza lo que había permanecido idéntico durante miles de años." (CHIRBES, 2000, p.173).

A história das três gerações representadas por esses personagens estão incorporadas à história da Espanha. Portanto, aquilo que José omite é silenciado e acentua o processo de 
esquecimento do passado. Essas lacunas são definidas por Quini como aquilo sobre o que ninguém pode perguntar ou aquilo de que todos sabem, mas se proíbe comentar:

Pero era curioso. Había cosas que no se podían preguntar nunca, y lo que no se podía preguntar nunca era lo único que de verdad habría que saber, porque eran los cimientos que sostenían las cosas. Podías hablar de las paredes, de las cortinas y los muebles, las anécdotas, a tu abuelo le gustaba, a tu padre decía, tu abuela cocinaba, tu madre no se lo creía, pero no podías enterarte del cimiento, eso no, de por qué él se llamaba Joaquín y de por qué Joaquín desapareció, qué vio su madre en su padre...Se podían saber las anécdotas, el viaje de novios, la playa de Jávea cuando ellos dos, Quini y Josemari no habían nacido, lo que la abuela regaló al abuelo cuando cumplió cincuenta años, lo que dijo un día el abuelo viniendo de El Escorial, eso sí, pero no lo otro, lo otro, sombras (CHIRBES, 2000, p.289).

Aquilo que Quini descreve como "cimiento" ou "sombras" representam as respostas para seus questionamentos sobre a composição das relações familiares. Seu avô omite a forma como enriqueceu com a venda ilegal de obras de arte, os acordos e contratos sujos que sustentavam sua empresa no mercado etc. As respostas para esses questionamentos encontram-se fragmentadas nos relatos de outros personagens que compõem a narrativa como as peças de um espelho quebrado.

Os silêncios e omissões presentes apenas na esfera individual e íntima são também devastadores para a história coletiva e instigam Tomás e Quini a questionarem quem são e quem realmente querem ser. Dessa forma, torna-se evidente uma sensação de asfixia gerada por um silêncio que percorre toda a narrativa e com esse "silêncio" a obra também reconstrói a memória social desse período histórico. O ambiente de tensão e instabilidade política, gerado pela censura da ditadura franquista extrapola o coletivo e invade a esfera privada.

Os relatos de José, Tomás e Quini sugerem que a construção da memória social consolida-se através da composição de interpretações individuais da história. Estas interpretações só se tornam possíveis por meio da sobreposição das vozes e da mobilidade do narrador onisciente.

A família Ricart abriga também personagens do núcleo doméstico. Este núcleo narrativo é protagonizado por Olga Ricart, pois ela é casada com Tomás, o herdeiro da família mais importante da Espanha franquista, e articula outras relações familiares. Abaixo dela encontram-se Elvira, Sole Beleta, Margarita, Ada Dutrel e Améia. A sogra de Olga, Amélia, decai na hierarquia familiar quando fica doente e depende dos cuidados da nora, que ocupa então o seu posto. Margarita almeja um casamento com Quini ou Josemari, fato que contribuiria para a manutenção de seu lugar na hierarquia social, visto que ambas as famílias 
acumulariam fortunas. Elvira e Sole também são herdeiras de importantes famílias franquistas. No entanto, o casamento de Elvira não a favoreceu economicamente, visto que Prudencio era um funcionário do Estado. Ela define Olga como o topo da hierarquia social quando a caracteriza como uma ditadora: "La vanidad, el afán dictatorial de Olga." (CHIRBES, 2000, p.123). Sole Beleta é solteira, estado civil desprezado que a inferioriza perante as outras mulheres. Ada Dutrel é uma artista em ascensão e, na hierarquia social, localiza-se abaixo de Olga porque, de certo modo, depende da colaboração dela para vender suas obras. Vale ressaltar que Olga é a responsável pela Fundação Ricart de arte e deseja que a fundação tenha seu nome após a morte do sogro. Carmem é a esposa da principal autoridade da polícia franquista, mas se enclausura em casa devido à constante violência que lhe é imposta pelo marido. Lurditas e Lina ocupam a base da pirâmide social, pois nos ambientes femininos, o trabalho era destinado para as mulheres menos favorecidas economicamente.

A obra possibilita uma imersão na condição das mulheres durante o período da franquismo, momento histórico em que foram modificadas as políticas de gêneros implantadas durante a Segunda Republica. Além disso, o romance conduz o leitor a refletir sobre esse ideal feminino que excluiu a mulher da vida política durante décadas e ainda existe de modo implícito, não apenas na Espanha. No período da Segunda Republica Espanhola, as mulheres experimentaram a possibilidade de integrarem-se na vida econômica, política e social do país. A Constituição Republicana instaurou políticas como a proibição da discriminação de gênero, concedeu à mulher o direito ao voto, assim como a equiparação dos direitos no matrimônio e a possibilidade de ocupar novos postos de trabalho com salário igual ao dos homens. No entanto, o regime franquista se opõe aos elementos progressistas associados ao regime republicano, assim como os direitos conquistados pela mulher. Eliminar as leis ${ }^{16}$ estabelecidas durante a Segunda República era um modo de silenciar as memórias desse período, destinando-as ao esquecimento.

\footnotetext{
${ }^{16}$ A situação econômica após a Guerra Civil e o peso da Igreja Católica também contribuiram para definir o papel da mulher na sociedade. Segundo Ismael Gonçalves Alves (2015, p.1): "Durante o franquismo homens e mulheres foram realocados em estruturas de gêneros tradicionais apoiados por sistemas de proteção social que contribuíam para a dominação de um gênero sobre outro". Nesse contexto promulgou-se o Fuero del Trabajo, uma das oito leis elementares do regime franquista que regula o trabalho feminino. Outras leis regularam e limitaram as conquistas da mulher durante a Segunda República, como Fuero de los Españoles que declarava a unidade familiar como base da nação, impedindo o divórcio, e a lei do Subsidio Familiar que gratificava financeiramente as famílias por cada filho nascido. Ambas exaltavam o matrimônio e a família com o objetivo de fomentar a natalidade entre a população espanhola, considerada muito baixa. Vale destacar a atuação da Sección Femenina de la Falange, instituição encarregada de difundir as novas orientações políticas e doutrinarias do franquismo atreladas a atividades de assistência social. Além disso, Franco entregou o direito da família à Igreja Católica que contava com a colaboração da Sección Feminina.
} 
A narrativa apresenta um panorama do reflexo dessas políticas no contexto da ditadura através do relato das personagens. Olga, por exemplo, não tem a consciência crítica de revisitar o passado histórico e relacioná-lo com sua existência. Limita-se a rememorar sua experiência pessoal para justificar suas escolhas e compreender sua função na família Ricart:

La mayoría de las asistentes a los cursos eran muy mayores. Las chicas de su edad no tenían tiempo para salir de casa, estaban en el nido, cluecas, incubando la pollada que puntualmente, iba creciendo. Las familias necesitaban hijos, y ellas estaban encantadas de tenerlos. <<Estoy otra vez, de cinco meses, sí, será el cuarto >>, comentaban cuando se encontraban con ella en alguna fiesta o a la salida de algún espectáculo, y ella aludía a su embarazo. $<<$ ¿Y tú qué? ¿Ya te has parado? ¿No vas por la niña? Nosotros no calculamos. Hemos decidido tener los que Dios nos dé>>, ponían caras de bobas para decirlos, mientras los maridos hacían bromas de mal gusto con Tomás y con el resto de los amigos que hablaban de su virilidad. <<Es que las embaraza solo con mirarlas $>$, y vulgaridades por el estilo. Y ella empezaba a ahogarse entre tanta estupidez. (CHIRBES, 2000, p.249).

Como se observa no trecho citado o narrador compartilha a opinião de Olga para apresentar um panorama das mulheres da época e aproxima-se de sua perspectiva quando caracteriza o comportamento feminino naquela sociedade como "estupidez". O trecho mescla a descrição onisciente com o monólogo interior indireto. Olga rememora o passado, quando a família ainda tinha expectativas de que ela tivesse uma filha e o narrador descreve, através do discurso indireto e dos marcadores textuais, aquilo que as mulheres diziam a Olga sobre a maternidade. Além disso, a presença do narrador está sugerida no início e no final da citação por frases bem articuladas, curtas e terminadas com ponto final, como: "Las chicas de su edad no tenían tiempo para salir de casa, estaban en el nido, cluecas, incubando la pollada que pontualmente, iba creciendo.”.O monólogo interior aparece entre as rememorações desses discursos, como se nota na sintaxe e no uso de frases mais longas: “... ponían caras de bobas para decirlos, mientras los maridos hacían bromas de mal gusto con Tomás y con el resto de los amigos que hablaban de su virilidad.”. A mescla entre a narração onisciente e o monólogo gera uma sensação de simultaneidade, pois Olga não apenas rememora aquilo que lhe disseram em outra ocasião, mas reflete sobre o fato quando caracteriza as amigas como bobas.

Embora, não seja possível definir com exatidão onde começa e termina a presença do narrador é possível inferir que ele compartilha da opinião do personagem, pois também se refere a essas mulheres com adjetivos pejorativos, como "cluecas" e "pollada". O incômodo do personagem não se aplica somente às outras mulheres, ela reflete sobre sua condição:

Hasta este instante no había advertido que el matrimonio, la maternidad, los quehaceres de casa, los compromisos sociales no eran solo un paréntesis en 
su vida, sino la esencia misma de aquello en lo que se había convertido su vida, que, de repente, se le reveló como una especie de tobogán por el que se había deslizado imperceptiblemente durante cuatro años, entre atenciones de los demás, halagos y obligaciones que parecían no serlo, un tobogán que sólo tenía una dirección posible - hacia abajo- y no admitía marcha atrás; o más bien, una cucaña bien enjabonada, porque la caída era picado. Se sintió como esos niños a los que se les obsequia con juguetes y caramelos envueltos en papeles de colores vivos para distraerlos de que van a sufrir una operación y cuando empiezan a sospechar el engaño ya están atados con correas al quirófano y una mano les pone implacable una mascarilla antes el rostro para narcotizarlos. Ella había percibido las correas de cuero en torno a sus muñecas - bañeritas de colores, tacataca, pañales -, había visto la mano sosteniendo la mascarilla - colonia nenuco, botes de leche en polvo, biberones - y había querido reaccionar. Fue lo que llamó su etapa fóbica matrimonial. (CHIRBES, 2000, p.251-252).

Aparentemente Olga rompe com os valores impostos durante a ditadura, pois os considera uma estupidez. Trata-se de uma mulher que possuía atitudes incomuns para o período histórico ao qual pertenceu, pois entrou na universidade e optou pelo uso de anticoncepcionais, recusando-se a ter mais filhos. Como se observa no trecho citado, Olga revela-se contrariada diante de sua função exclusiva de mãe e esposa e tenta romper com essa imposição. Em parte, obtém êxito, pois se torna a responsável pela fundação de arte financiada pelo sogro.

No entanto, o êxito de Olga também se deve ao privilégio de pertencer a uma família com poder e dinheiro suficiente para negociar obras de arte sem passar pelo crivo da censura, principalmente tratando-se de arte vanguardista. Segundo a perspectiva de Elvira, a possibilidade de estudar na universidade tampouco é uma conquista pessoal, mas uma conveniência para a família que enriqueceu traficando obras de arte. Além disso, os estudos não são concluídos, fato que reafirma, por um lado, a convenção social e, por outro lado, reitera o caráter frívolo do personagem: “....y que por eso había querido Olguita hacer historia y aprender arte en la universidad, pero parecía claro que lo de los estudios no iba con ella, y tuvo que dejar la carrera sin acabar..." (CHIRBES, 2000, p.138).

O discurso de Olga também reforça a ideia de limitação da mulher à esfera doméstica. Ela rememora uma conversa com a amiga Sole Beleta em que tenta impor e caracterizar homens e mulheres de acordo com suas concepções: homens seriam como animais carnívoros e estariam associados ao inverno, enquanto as mulheres seriam consideradas herbívoras e identificadas com o verão:

'La primavera es estación femenina - se atrevió a decir -, y también el verano es una estación de mujeres...' Prosiguió ya imparable: '...el sol, ¿no te das cuenta, Sole, de que los hombres no soportan el sol? Y nosotros, en 
cambio, despatarradas en la playa, seis, siete horas seguidas, en la arena ardiente del Mediterráneo: ahí, las salazones, el sol y los pescados pequeños. Los pececitos retorciéndose en la sartén. La primavera son las verduras, el romanticismo; el verano, el sol, la playa, la pasión física. Las dos estaciones, femeninas, no te quepa duda. Otoño e invierno, en cambio, las estaciones masculinas, llenas de ocultaciones: ropas pesadas que cubren todo el cuerpoy disimulan las formas; caza, grasas, cocidos y potajes; sitios cerrados, chimeneas, bares, habitaciones que huelen a tabaco, a café y a coñac. A los hombres les favorece ese tiempo. Son más atractivos vestidos que desnudos: el cuello rodeado por una camisa blanca; la chaqueta disimulándoles las deformidades, tapándoles el abdomen; los pantalones, ocultándoles las piernas' (CHIRBES, 2000, p.42-43).

A intenção de Olga ao comparar homens e mulheres com estações do ano e vegetais era definir-se como superior a Sole, pois a amiga não se adequava aos padrões daquela sociedade, além de não ser casada, não correspondia aos atributos físicos e ao modo de vestir definidos como padrão para a época: "Olga le hablaba a Sole desde su butaca, pero sobre todo, desde el alto mirador su experiencia de mujer casada que conocía bien los gustos de los hombres [...]" (CHIRBES, 2000, p. 41). Através de seu discurso Olga não só reproduz, mas impõe a outras mulheres o discurso opressor do regime franquista. Ela atua como opressora e oprimida, pois foi vítima de violência sexual no passado e aproveita-se de sua condição social para humilhar outras mulheres. A obsessão de Olga pelas verduras, por Paris e pela arte vanguardista representam os elementos que precederam sua experiência traumática:

Era la noche más feliz de su vida, y ya casi amanecía cuando pasaron entre los montones de cajas de Les Halles y el tumulto de furgonetas y los gritos de descargadores. Olga veía las etiquetas que marcaban en las cajas nombres de poblaciones que ella conocía bien, no muy lejos de Jávea, y desde las que llegaban las verduras y fruta; lugares de los que habló a aquel hombre que la escuchaba con atención y se interesaba por todo lo que le pertenecía a ella [...] Con esa sensación de felicidad, de que el mundo era un pañuelo que ella podía meterse en el bolsillo, cruzó la Pont des Arts dejándose abrazar y besar por su acompañante (CHIRBES, 2000, p.258).

Numa viagem para Paris, ela conhece um professor de arte chamado Jaques que a encanta com sua cultura e com a paisagem local, pois passeiam pela romântica Pont des Arts. No entanto, ele a conduz para um local afastado, caracterizado pela presença de restos de verduras, frutas e a violenta. $\mathrm{O}$ personagem romantiza os elementos que remetem a situação traumática, assim torna-se obsecada pela arte, pelas verduras e por Paris. Essa obsessão é justificada pelo personagem como um estilo:

Aplicaba a las verduras la misma estrategia que a los irrepetibles objetos que regalaba; las envolvía en - el jersey del estilo - con historias que las hacían brillar cegadoras: en eso, como en algunas otras cosas - escepticismo en 
materia de religión, su pasión por Paris y por la pintura más atrevida - podría decirse que fue una precursora. (CHIRBES, 2000, p.40).

'Fíjate, en todo un Madrid. Qué diferencia con París. Está claro, Madrid no es una ciudad de verduras, no hay tradición; en Madrid, olvídate de las salazones y de las verduras que no sean sota, caballo y rey.' (CHIRBES, 2000, p.42).

Ela reproduz a humilhação sofrida em pequenas escalas, pois utiliza sua veneração pelas verduras e por Paris para menosprezar Sole e Elvira. As amigas são suas principais vítimas, pois se encontram abaixo dela na hierarquia social. Olga descreve as verduras como típicas do estilo feminino com a finalidade de isolar Sole deste universo, visto que ela não se enquadrava nos padrões. Além de ser solteira, não ter filhos e vestir-se de modo diferente das outras mulheres, Sole era dona de uma produção de presuntos. Portanto, o objetivo de Olga ao relacionar a masculinidade como algo carnívoro era rebaixar Sole, distanciando-a do universo idealizado pelas mulheres da época. Sole tenta defender-se ao sugerir que poderia levar aspargos para o bufet:

Era evidente que lo había dicho para defenderse de la agresión vegetal de Olga la había sometido, y también, sin duda, para envolverse en un rastro de perfume varonil: los espárragos habían pasado por las manos sudorosas de los braceros que los recolectaban en las dehesas extremeñas y se les acercaban al vientre para atarlos, y mordían las tiras herbáceas que utilizaban de modo de cuerdas (CHIRBES, 2000, p.44).

No entanto, o narrador revela sua fragilidade quando relaciona os aspargos com o suor e a saliva masculina. As comparações do narrador retomam ideia de submissão imposta pelo regime e pela igreja católica, pois para sentir-se segura diante da agressão de Olga ela indiretamente associa sua imagem a elementos masculinos, simbolicamente presentes nos aspargos. Além disso, o narrador evidencia a competição entre as amigas através do termo “agresión vegetal”. De certo modo, Sole isola-se socialmente, pois não cumpre os requesitos estabelecidos pela Falange. $\mathrm{O}$ papel da mulher estava tão ligado à maternidade e à família que não era possível enxergá-la de outra perspectiva:

La olió y, cuando levantaba la cabeza, su mirada se encontró con la de Sole Beleta, que había estado vigilando la relación que Pruden establecía con el jamón como una madre vigilaría a su hijo menor que se ha puesto a jugar en el parque con un pederasta recién salido de la cárcel (CHIRBES, 2000, p.125).

Novamente Sole é associada a carne, elemento definido por Olga como masculino. Elvira a caracteriza como maternal ao descrever o empenho da amiga em impedir que 
Prudencio coma o presunto: "vigilando la relación que Pruden establecía con el jamón como una madre vigilaría a su hijo menor...". Embora o trecho citado apresente a perspectiva do narrador, revelam-se os pensamentos de Elvira. A relação materna que ela estabelece entre Sole e o presunto é conteúdo constante da consciência de Elvira que representa uma típica mulher franquista, dedicada exclusivamente a família e ao casamento.

Elvira e sua filha Margarita ocupam o mesmo espaço que Sole na hierarquia social, pois são herdeiras de uma família tradicional. Elvira é filha de Sebástian Barcia, um homem importante para a ditadura, pois ajudou a financiar a Guerra Civil em apoio ao general Franco: ...don Sebastian Barcia financió el alzamiento, estuvo en el frente, y, mejor aún, en la retaguardia, negociando con los ingleses y con los americanos la llegada del material de guerra, ¿o no le dijo Franco delante de un montón de ministros del gobierno y de no sé cuántos embajadores: <<Sebastián, yo he ganado la media guerra, la otra mitad me la ganaste tú>>? (CHIRBES, 2000, p.135).

A narrativa de Elvira organiza-se em torno das observações frustradas sobre seu casamento e de suas comparações com a vida de Olga Ricart: "Elvira, por su parte, no dejaba de mirar a Olga como una advenediza." (CHIRBES, 2000, p.134). De acordo com a perspectiva de Elvira, a família de Olga e Tomás tinham interesses comuns, pois ambas enriqueceram com o tráfico de obras de arte, assim como o matrimônio entre eles tinha como função de manter seus lugares na hierarquia social, pois selava a união das heranças e dos interesses familiares.

Como um contraponto à perspectiva de Elvira, Olga apresenta uma visão heróica sobre sua vida. Ela decide casar-se com Tomás após ser violentada por um homem pelo qual estava apaixonada: “...y una vez que la hubo derribado, se metió entre sus piernas, forzándola, haciéndole daño.” (CHIRBES, 2000, p.259). A experiência traumática a faz sentir-se humilhada, conduzindo-a a reformular o modo como enxerga o mundo. Observa-se no personagem uma necessidade de poder que o dinheiro de Tomás poderia oferecer: "Olga había entendido que el sexo es el impulso primero, y el dinero, la posición, lo que pone en su sitio y ordena." (CHIRBES, 2000, p.263). Portanto, ela decide casar-se com Tomás por interesse financeiro. Mas, percebe tardiamente que o casamento era um acordo e que deveria cumprir uma função na família. O casamento também é visto por Elvira como um negócio e constitui sua principal preocupação em relação ao futuro de sua filha Margarita.

Durante a juventude Elvira e Olga disputavam a atenção de Prudencio, portanto, pensar sobre a vida de Olga a faz rememorar seu passado. O narrador compartilha da imagem 
negativa que Elvira apresenta da rival, aproximando-se da perspectiva do personagem e, muitas vezes, apropriando-se de seu discurso:

Acababa de volver de la peluquería, por culpa del chaparrón que cayó cuando estaba entrando en el portal, casi se le descompuso la permanente que le habían hecho un rato antes. Por si fuera poco, en cuanto abrió la puerta de casa se enteró de que Pruden le había dejado un recado a la chacha diciéndole que no lo esperase, que saldría tarde de la oficina y se presentaría él por su cuenta en la fiesta de los Ricart. Menos mal que Marga iba a pasarse a la hora de comer y pondrían salir juntas. Aquél cumpleaños era un fastidio que le trastocaba un montón de planes. La vanidad, el afán dictatorial de Olga. Cualquiera le decía que no podía asistir (CHIRBES, 2000, p.123).

Como se observa no trecho citado há um desdobramento temporal e a narrativa concentra-se no tempo subjetivo, em que se alternam as perspectivas do narrador onisciente e do monólogo interior indireto. São as ações do tempo objetivo que desencadeiam as rememorações do personagem no inicio do relato. O enredo concentra-se no tempo objetivo a princípio, pois se utilizam verbos "cayó", "abrió" e "enteró", no pretérito perfeito do indicativo. Por meio destes verbos o narrador refere-se à chuva, situando temporalmente a narrativa, descreve a chegada de Elvira em casa e transcreve a notícia de que seu marido não irá buscá-la para a festa da família Ricart. A combinação destas ações propicia o desdobramento temporal para o tempo subjetivo, pois desencadeiam rememorações e reflexões do personagem. O tempo subjetivo tem inicio com a perspectiva do narrador que se aproxima de Elvira e apropria-se de sua opinião, movimento que se revela através do termo "menos mal". Esse termo reflete a indiferença do personagem em relação à ausência do marido. O matrimônio é uma temática recorrente no relato de Elvira, pois revela seu ponto de vista sobre o papel da mulher da na sociedade. A perspectiva do narrador é sinalizada através das orações que se organizam de modo coerente de acordo com a semântica e a sintaxe.

Além disso, a descrição da festa como um "fastidio" e as referências a Olga Ricart como "la vanidad, el afán dictatorial" revelam opiniões que o narrador compartilha com Elvira. Outros aspectos que indicam a perspectiva do narrador, assim como sua falta de afinidade com Olga são o conteúdo das interpelações e o uso do pronome pessoal átono "le" que podem ser observados no trecho:

Nada más que a Olga se le ocurría celebrar aquél cumpleaños, estando como estaba su suegra (¿qué haría con ella? Aquella mujer no estaba para visitas), y en una tarde en que la noticia de la muerte del Caudillo podía llegar de un momento a otro. No podía haber elegido peor día. Encima; a Elvira le habían regalado unos días antes entradas para la sesión de esa noche en el Eslava que, claro está, no podría usar; y, por si fuera poco, había un pase de moda a 
las siete en casa de Manina Muñiz que, evidentemente, también se perdería [...] Recordó el último cumpleaños que había celebrado el viejo, antes de que doña Amelia se pusiera peor, y lo hizo con una sensación de aburrimiento, de déjà vu. También aquel día había acudido Pruden por su cuenta. Había entrado en el salón de los Ricart, mirando a todas partes con ese gesto congénito de fastidio que le concedía su miopía, mientras ella se dejaba coger del antrebrazo por la larga mano de Olga y charlaba, así cogida, en el centro del salón: <<precioso bufé, preciosas flores^〉>, se acercó a ellas y casi introdujo la nariz en el centro del centro fingiendo interés... (CHIRBES, p. 123-124, grifo do autor).

As interpelações do narrador marcadas textualmente entre parênteses ressaltam sua indignação pela realização da festa diante do estado de saúde de Amélia. O uso do pronome pessoal átono "le" indica uma referência à Elvira como terceira pessoa do singular e acentua a perspectiva do narrador. Ele sinaliza o início do monologo interior com a frase: "Recordó el último cumpleaños que había celebrado el viejo...” (CHIRBES, 2000, p.124). Em seguida, nota-se que gradualmente a narrativa modifica-se através da pontuação, pois o parágrafo continua por um longo período sem o uso do ponto final, com frases separadas apenas por vírgulas e marcadores textuais de oralidade. Além disso, ressaltam-se as impressões de Elvira sobre a festa, como a sensação de tédio que marca a repetição dos termos "deja $v u$ " e "aburrimento". Novamente destaca-se o distanciamiento entre Elvira e Prudencio, visto que a ausencia do marido era constante: "También aquel día había acudido Pruden por su cuenta.". A rememoração da última festa na casa da família Ricart conduz o personagem a refletir sobre o comportamento do marido e, consequentemente, sobre seu casamento. A relação entre Elvira e Pruden é constituída por conveniências econômicas e sociais. Prudencio também atribuía ao casamento um valor social, pois representara a ascensão econômica que tanto desejava:

Entonces fue cuando se dieron las dos cuenta de que cada una recibía a Pruden como destinataria del amor que parecía emanar de él. La conclusión que sacó Olga fue que, en realidad, le daba lo mismo la una que la otra; que de lo que Pruden estaba enamorado era de su posición - de la de las dos-, o, por decirlo de otro modo, de su dinero (del de las dos), y que se excitaba de manera indistinta con cualquier cuerpo que cumpliera las expectativas que él alimentaba: soporte económico (CHIRBES, 2000, p.128).

...pensaba Elvira en silencio durante las horas en las que Pruden lo retenían sus negocios y compromisos y a ella le tocaba esperarlos a solas, y notar cómo se le llenaba la garganta con un regusto amargo." (CHIRBES, 2000, p.135). 
Através dos monólogos e da narração onisciente nota-se que para Elvira o casamento é uma garantia da inserção social da mulher. Ela reforça a ideia imposta pelo regime franquista e pela Igreja católica de que a mulher devia encarregar-se da família e empenhar-se durante toda a vida para cumprir tal objetivo. Portanto, sua participação social na narrativa restringese a sua condição de filha, mãe e esposa. No entanto, nota-se uma contradição entre seus valores quando ela se revela infeliz e arrependida de casar-se com Prudencio: "Era como si sólo él tuviera aquello que Elvira tanto necesitaba. Qué tonta había sido." (CHIRBES, 2000, p. 140). Mesmo diante de sua frustação ela se empenha em convencer o marido da importância de um casamento financeiramente atrativo para a filha Margarita: "No te olvides de que tienes una mujer y una hija, y qué quieres, ¿casar a tu hija con un vaquero de Béjar, o con el dueño de una pescadería de Coruña?” (CHIRBES, 2000, p.132).

O narrador explora a consciência de Margarita, usa a repetição, revelando que as normas da tradição católica franquista defendidas com vigor por Elvira atingiam sua filha que representa a nova geração. A jovem rememora constantemente as palavras da mãe: “...imagínate lo que es una mujer sola, sin família... sin darte cuenta, te has quedado sin futuro, porque tu futuro era aquel muchacho que se te escapo porque estabas distraída...” (CHIRBES, 2000, p.222-223). Seu relato tem início com rememoração de uma ordem sempre repetida por Elvira "<<Margarita aparta las rodillas...>>" (CHIRBES, 2000, p.221) e se estrutura em torno das interpretações que dela faz Margarita, principalmente sobre o termo "las rodillas". Os fragmentos de suas rememorações e reflexões sobre a simbologia dos joelhos somam-se aos comentários do narrador compondo a perspectiva do personagem:

O sea, que las monjas decían arrodilaos y su madre junta las rodillas, y eso era la derecha; y la Pasionaria no quería arrodilarse, y eso era la izquierda. Las rodillas, en elemento simbólico, como los escudos o las banderas. (CHIRBES, 2000, p.224)

Embora, aparentemente, Margarita despreze as regras de conduta reproduzidas pela mãe, o narrador apresenta a jovem como uma herdeira desses valores. O termo "rodillas" é uma metáfora, pois o personagem reflete sobre a representação simbólica dos joelhos em diversos âmbitos, como a relação ideológica entre direita e esquerda, a infância no colégio católico em que ajoelhar-se era uma forma de castigo, as palavras sobre liberdade da Pasionaria e a conotação sexual à qual se referia Elvira. A perspectiva narrativa oscila entre as rememorações de Margarita em que se destacam as ideias de Elvira, as reflexões do personagem que contesta essas ideias e a posição do narrador em relação a elas: 
Lucas, Pedro, Quini, Josemari, Javier, el pobre Javier, sobre todo él. Los hombres querían apartalas porque eran el cierre que les impedía llegar allí, a ese punto que era una Diana, y en el que se concentraba una conjunción de fuerzas contradictorias, aunque poderosas - lo insinuaba su madre a todas horas-, conseguiendo que allí estuvieran al mismo tiempo la cumbre y el abismo, como en esos montes más altos en cuyos picos se encuentran fósiles de peces y de moluscos porque un día fueran las mayores profundidades submarinas. Cumbre y abismo a la vez. Tenía razón su madre. Abismo. (CHIRBES, 2000, p.225).

A frase citada sugere uma mescla entre o monólogo interior indireto e o momento em que se apresenta a perspectiva do narrador. A princípio, as orações são pouco articuladas e há repetição de palavras, como "Javier" sugerindo o uso do monólogo interior. Após uma sequência de frases longas a estrutura da narrativa organiza-se em períodos curtos e objetivos. A presença de marcadores textuais introduzem comentários do narrador: "- lo insinuaba su madre a todas horas”. O narrador reaparece no final da citação, mas não utiliza a marcação textual para fazer uma afirmação: “Tenía razón su madre. Abismo." Sua presença está implícita através do conteúdo da frase, pois apresenta uma possível resposta para as dúvidas da jovem acerca do sexo, um "abismo". Nota-se que as duas frases finais são nominais e mimetizam uma mistura da fala da mãe, da interpretação que a ela dá a filha e da visão do narrador sobre o convencionalismo dos hábitos cotidianos instalados pelo Estado e pela Igreja. Conteúdos conclusivos não estão no repertorio de Margarita, visto que a jovem não apresenta opinião formada sobre o assunto: "No sabía nada de casi nada. Se llamaba a si misma ignorante. <<Ignorante, soy una ignorante>>..." (CHIRBES, 2000, p.236)

A presença masculina se faz presente na consciência de Margarita de forma direta ou indireta. Ela se refere diretamente aos homens que deseja através do monólogo interior: “Pedro. Quini. Lucas. Josemari. Juan Bartos. Javier. El bueno de Javier.”(CHIRBES, 2000, p.226). De modo indireto suas rememorações revelam sua experiência e intenção com cada um dos nomes mencionados:

Le gustaba mucho el profesor Bartos, la voz, los gestos, las manos sonrosadas y anchas, los ojos de miope detrás de las gafas. En una escala descendente (es decir varios escalones más abajo), y dada la inaccesibilidad del profesor Bartos se situaban las expectativas de Margarita en una lucha sentimental entre Quini y Pedro Macías. (CHIRBES, 2000, p.231).

O narrador recorre à interpelação para dirigir-se diretamente ao leitor e enfatizar a informação que hierarquiza o desejo de Margarita e define o professor Bartos como seu principal alvo: “(es decir varios escalones más abajo)”. Essa informação ressalta uma face tola do personagem ao repetir a típica ilusão adolescente de amor entre professor e aluno. A 
hierarquização em que ela situa os homens desejados coloca em pauta sua intenção com o grupo de estudos. Em suas rememorações quando faz referências ao grupo de discussões filosóficas do qual participa, Margarita refere-se apenas à presença masculina como objeto de desejo sexual ou matrimonial. Apenas o narrador faz alusões aos temas debatidos e às leituras realizadas pelos alunos. O interesse de Margarita não está propriamente relacionado com as ideias e o conteúdo dos debates, mas com a presença de Juan Bartos, Quini e Lucas. Assim como idealizava a Sección Feminina de la Falange, os desejos e anseios de Margarita organizam-se e submetem-se em torno do gênero masculino. Vale ressaltar ainda que, embora se sinta atraída por eles, restringe as possibilidades de casamentos apenas aos herdeiros da família Ricart. Margarita imagina-se casada tanto com Quini quanto com Josemari, desde que cumprissem suas expectativas de matrimônio: “...se escurría y saltaba como un gato, y eso hacía que no trasmitiera la calma, la seguridad que Margarita le pedía al hombre con el que pensaba compartir su vida." (CHIRBES, 2000, p.232).

No era precisamente desagradable tener un marido [Josemari] así, al que puedes enviar de madrugada a comprarte un refresco, porque estás embarazada y tiene un antojo; un marido al que puedes decir: <<Ahora mira, mira lo que hago, pero tú te tiene que estar quieto, sin tocar, y ahora... (CHIRBES, 2000, p.235).

Margarita é uma jovem instruída, militante e capaz de refletir de modo crítico sobre o contexto histórico em que vive. No entanto, está socialmente condicionada a repetir os padrões impostos pela geração anterior. Desse modo, reproduz as palavras e o comportamento da mãe:

$<<$ Un hombre lleva su ropa y su cartera, y si está en ambientes muy exclusivos, su inteligencia, y con eso se basta, pero una mujer tiene que llevar siempre acompañante, y, de joven, la mitad de su ropa es la pandilla de amigas, y, cuando madura, el muchacho que lleva al lado por más que sea un cenizo, un imbécil. El cuerpo femenino no se acuerda con la soledad. La soledad en público desnuda a la mujer, provoca escándalo >>, le explicaba a Pilar, la compañera con la que había alquilado el apartamiento en el que, desde hacía unos meses, vivía (CHIRBES, 2000, p.226).

A representação da consciência de Margarita revela que, embora seja herdeira de uma família franquista, ela é capaz de refletir sobre a condição da mulher, há uma tomada consciência do contexto histórico em que estava inserida, assim como uma tentativa de ruptura. No entanto, essa reflexão não é suficiente para transformá-la e, assim como Elvira, seus anseios estão relacionados ao matrimônio. Portanto, a perspectiva onisciente apresenta mãe e filha com personalidades diferentes, mas a associação da voz das personagens às 
insinuações do narrador, quando capta suas consciências, revela que tanto em Margarita quanto em Elvira refletem-se os valores do franquismo.

Essa possibilidade de reflexão crítica sobre o contexto histórico em que estava inserida Margarita não se aplica a Carmem e Lina. A incompreensão do contexto associado a outros fatores como a violência conduz essas personagens ao isolamento social. Os relatos de Carmem e Lina estruturam-se em torno de seus relacionamentos com Arroyo e ressaltam o papel submisso da mulher. Tanto em Carmen, quanto em Lina, nota-se a repressão exercida pelo delegado através da violência sexual e do sentimento de culpa. Lina é marginalizada por sua profissão e Carmen sente-se marginalizada porque não atende o padrão do marido relativo à maternidade como uma das finalidades do casamento.

A estrutura do relato de Carmem revela que sua vida está estritamente condicionada ao matrimônio, pois no tempo objetivo suas ações são determinadas somente pela presença do marido. Vale destacar ainda que as ações são de teor submisso em que o personagem apenas responde aquilo que lhe é perguntado. O tempo objetivo é composto por alguns minutos de duração, surge no inicio do fragmento narrativo com uma pergunta de Arroyo: "Se acerco a ella y le preguntó: << ¿Ya estás arreglada?>> (CHIRBES, 2000, p. 292). O tempo objetivo é retomado apenas uma vez, no final do relato com a resposta de Carmem: "Respondió: $<<$ Sí, ya estou arreglada. Nos vemos cuándo tu digas >, pero él se había metido en su despacho outra vez y hablaba por telefono con alguién." (CHIRBES, 2000, p.301). No intervalo entre a pergunta de Arroyo e a resposta de Carmem há um desdobramento temporal para a subjetividade através da aproximação do narrador:

Lo había esperado ante al veladorcito cubierto con un tapete de ganchillo encima del cual dejaba las labores en las que se entretenía por la tarde, al lado de la ventana del salón que daba a la calle. Le gustaba sentarse allí, sobre todo en invierno, cuando, a esa hora de la tarde, después de que veía el telediario y recogía la mesa, podía envolverse en luz de sol; se quedaba acariciada por el sol de la tarde de invierno hasta que se levantaba a encender la lámpara porque ya no podía seguir cosiendo con la luz natural. Entonces, echaba las cortinas y cerraba los postigos de las contraventanas, porque le parecía que, de no hacerlo, le faltaba intimidad, se sentía vigilada en sus quehaceres desde las casas de enfrente y esa sensación la incomodaba (CHIRBES, 2000, p.292).

O narrador introduz termo "ventana" que pode ser interpretado como a liberdade perdida ou isolamento do personagem que se limita à assistir a vida da janela. Esse comportamento revela sua postura passiva diante da vida, pois Carmen estava impossibilitada de reagir diante da repressão e da violência praticadas pelo marido. $\mathrm{O}$ ato de fechar a janela e 
a cortina porque se sentia vigiada indica que ela impõe a si a repressão que outrora era realizada pelo marido ${ }^{17}$. Essa ação reflete a doutrinação que a igreja e a Sección Feminina de la Falange exerciam sobre as mulheres, de modo elas construíam suas próprias prisões, vigiavam umas as outras e sentiam-se vigiadas. Além disso, ressalta-se o papel submisso da mulher e sua função relegada a esfera doméstica:

...porque la culpa - lo decía así, <<la culpa >> - de que no tuviesen hijos era, sin duda, de ella; por eso fue terrible cuando, al final de las revisiones, el médico le dijo algo acerca de sus espermatozoides, le dijo que eran débiles, o algo por el estilo... Por fin, un día estalló y le pregunto con malos modos si no había tenido bastante con no haber tenido bastante con no haber conseguido hacerlo padre para encima haberlo rebajado como hombre. Podía recordarlo meses después, metiéndose a oscuras en la habitación y penetrándola a la fuerza, montándose sobre ella a oscuras, sin ni siquiera molestarse en mirarla a la cara, o en preguntarle si quería o si no, y ella calada, soportando, y él insatisfecho con su silencio, preguntándole o afirmando: <<Te da gusto. $>>$ Se repitió la escena otras muchas noches, y en las pocas ocasiones en que ella se ocurrió decirle que le hacía daño, $<<$ por qué no lo hacemos tranquilamente, así me duele〉>, le dijo, él le apretó la cabeza contra la almohada como si quisiera asfixiarla. « ¿Puedo o no puedo?>>, le decía, mientras la empujaba y la mordía. (CHIRBES, 2000, p.295-296).

Embora, Carmem represente uma esposa submissa e dedique-se exclusivamente ao lar, não cumpre a função social da maternidade. Desse modo, rompe com o valor da família tão exaltado pelo regime franquista e pela igreja católica. O casal não teve filhos por problemas de saúde de Maximino Arroyo. No entanto, ele se recusa a aceitar essa condição e culpa a esposa. O sentimento de culpa também está presente no relato de Lina, a amante Arroyo:

Entre tanto, Adela Chércoles Renedo, Lina, pensaba que eso era lo que decía él, que, por ella, por la forma de ser de ella, se había vuelto loco aquel hombre, y cuando le daba por pensar así, hasta se sentía un poco culpable (CHIRBES, 2000, p.182).

Lina ocupa a base da hierarquia social, pois prostituia-se para manter a família. Seu relato estrutura-se em torno de sua relação com Arroyo e revela sua frustração por não ter uma família constituída como a do modelo vigente. Ela associa a presença masculina como única possibilidade de transformar sua vida, por isso quer encontrar um marido e um pai para seu filho:

Ella sí que tenía a su hijo, ella sí que tendría que buscarle un padre a su hijo, y buscarse un amigo, un marido, alguien que los quisiera al niño de verdad, que se preocupara de verdad de lo que necesitaban y de lo que no, de dónde

\footnotetext{
${ }^{17}$ Ao referir-se a imagem da janela, Rafael Chirbes realiza uma referência ao ensaio Desde la ventana: enfoque feminino de la literatura española (1988), de Carmen Martin Gaite.
} 
estaban y que hacían, no como él, que era un vicioso. Pero resultaba que no podía hacerlo, buscar a alguien que la quisiera de verdad, cómo iba a hacerlo, con él detrás, oliéndole las bragas como un perro, qué se iba a buscar ella. (CHIRBES, 2000, p.180).

Portanto, ambas as mulheres vinculadas a Arroyo sentem-se vítimas da violência masculina. Embora ocupem lugares diferentes na pirâmide social, elas tendem a isolar-se. Lina recorre a uma profissão marginalizada pela sociedade e Carmen também se sente na margem social porque não desempenha o papel da maternidade. A presença de uma esposa e uma amante representa uma prática comum da classe média que se torna explícita na narrativa através de Maximino Arroyo.

Em contraponto a Carmem e Lina, encontra-se Ada, uma artista plástica reconhecida que busca ascensão no mercado da arte: “...discretamente cotizada y muy respetada en el mercado español de arte de vanguardia.” (CHIRBES, 2000, p.194) . Ela se diferencia das outras personagens porque é politicamente ativa e através de suas obras, busca retratar a ditadura. Ainda que por trás de sua militância encontrem-se interesses pessoais e sua obra seja ironizada pelo narrador, ela consegue romper com o estigma dos valores impostos às mulheres:

Ella les había regalado a los del pecé una de las series con innegable emoción, pero también con un punto de interés que ni a si misma se atrevió a confesarse, ya que la red de galerías que los plásticos comunistas controlaban y en la que organizaban sus exposiciones era seguramente la más prestigiosa del país. (CHIRBES, 2000, p.198).

No entanto, Ada é constantemente relacionada por Bartos ao espaço doméstico, nem seu trabalho artístico e sua atuação na resistência antifranquista são encarados por ele como algo profissional, mas como um "de juego, de deporte". Como se observa nos fragmentos citados, o personagem não tem voz narrativa, sua perspectiva é apresentada pelo narrador que adere à perspectiva de Juan Bartos para descrevê-la e, posteriormente, insere-se na perspectiva de Ada para apresentar Juan. Desse modo, fragmentam-se os relatos e Ada é representada a partir de uma perspectiva masculina que, reforçando os valores da época, exalta sua função na maternidade e no matrimônio:

Por toda esa ingente actividad pública que desarrollaba, Jaun Bartos pensaba que su mujer estaba más hecha para la acción que él, y tal pensamiento le hacía sonreír porque, referido a Ada, el término acción, o el término activista, adquirían un toque familiar, doméstico, que enlazaba la agitación revolucionaria con la más enternecedora actividad cotidiana: bañar a los niños y ayudarlos a hacer los deberes, limpiar la piscina de la sierra, preparar una purrusalda, o un pil-pil, ordenar los libros, cortar el césped, o aplastarle un grano que le había salido a Juan en la espalda y mostrarle la punta 
amarillenta del pus. Con ese mismo espíritu se enfrentaba Ada a su obra, a sus reuniones con los artistas más politizados, asistía a conferencias, firmaba manifiestos y apoyaba cualquier iniciativa; con sentido de trabajo doméstico cumplido, de juego, de deporte (CHIRBES, 2000, p.198).

Mesmo tratando-se de uma mulher culta, instruída e politicamente ativa, Ada é valorizada por sua capacidade de dedicação à vida conjugal que é definida por Bartos como a manutenção da casa e a preocupação em agradar o marido nos pequenos detalhes. $\mathrm{O}$ matrimônio de Juan e Ada repete o mecanismo de herança dos vencedores para garantir a posição social dos filhos, visto que as despesas da família não dependem de Bartos. Seu casamento com a artista lhe garante recursos financeiros, pois ela é herdeira de uma fortuna e destaca-se no mercado da arte:

...y ni siquiera dependía económicamente la familia del modesto sueldo de ayudante en la universidad que él percibía, puesto que, además de que sus cuadros se vendían cada día mejor, la familia de Ada era propietaria de una empresa metalúrgica y de varios inmuebles tanto en Madrid como en Santander (CHIRBES, 2000, p.194).

Assim como Ada, Lurditas tinha uma profissão, era cozinheira na casa da família Ricart. No entanto, ela não apresenta consciência social do contexto político em que está inserida. Sua perspectiva dependia daquilo que Lucio ensinava a ela, até mesmo o conceito de matrimônio foi determinado por ele: “...los pobres no tienen que guardar las aparencias, sino que tienen que cumplir lo que sus sentimientos les dicen y mis sentimientos me dicen que te quiero y no necesito ningún papel de nadie...” (CHIRBES, 2000, p.87). Lurditas desejava casar-se no cartório, mas Lucio não concordava, pois considerava essa atitude um valor burguês:

Decía ella: <<Soy tu mujer >>, y él le respondía que no, que las personas no eran propiedad de nadie. A ella no le importaba ser propiedad de él, pero también le parecía bien que le dijera que los dos era iguales, no propiedad el uno de lo otro, sino iguales, compañero y compañera, y eso lo decía también el padre Llanos: <<Las mujeres son vuestras compañeras >>, y la verdad es que también era bonito: se juntaban en el bar con más gente, él le pasaba el brazo por encima de los hombros, y decía: $<<$ Se llama Lurditas y es mi compañera. > Eso fue cuando iban por el Pozo y tenían amigos allí, luego él había empezado a volverse más huraño y misterioso y ya no iban ni a la iglesia ni al bar (CHIRBES, 2000, p.88).

Durante toda a trajetória da ditadura a igreja católica foi um veículo de controle. No entanto, vale destacar que também foi núcleo de agitação no fim do franquismo. Lurditas e Lucio frequentavam uma igreja construída por trabalhadores e militantes do movimento 
operário. A relação entre eles era supostamente baseada na igualdade. No entanto, Lucio a persuadia, convencendo-a daquilo que era conveniente para ele. Visto que ela não tinha acesso ao conhecimento ou à cultura era facilmente conduzida e não havia necessidade de impor ordens ou repressão. Lurditas não era estimulada a desenvolver sua reflexão sobre os fatos, apenas repetia aquilo que Lucio lhe ensinava: "Lucio leía libritos de papel amarillento, usados y pegajosos, y que hablaban de revolución, comunismo, facismo, proletariado y lucha de clases, y le explicaba lo que cada una de esas palabras quería decir;" (CHIRBES, 2000, p.88).

Através dos relatos das personagens femininas é possível afirmar que as políticas de controle do franquismo estendiam-se às famílias de todas as classes sociais. $\mathrm{O}$ franquismo radicalizou a oposição homem/mulher como modelo com o objetivo de atribuir ao feminino somente o espaço doméstico e exaltar a subordinação como uma virtude, afastando a mulher da vida política. Para atingir essa finalidade foram utilizados todos os instrumentos institucionais, sociais e religiosos, como as políticas de gênero, as leis, as instituições educacionais e a Igreja. O regime elaborou e realçou certos valores que se deveriam atribuir à figura da mulher. A aliança ente Estado e Igreja atuava também na vida privada, elaborando modelos de masculinidade e feminilidade em que a mulher estava estritamente ligada a tarefas domésticas e a maternidade.

As aspirações de emprego, de educação formal, igualdade no matrimônio e participação política foram consideradas ameaças e, portanto, excluídas do universo de possibilidades. Margarita, Ada Dutrel destoam das outras personagens porque aspiraram à igualdade em seus discursos. No entanto, na prática também estavam inseridas em uma tradição franquista. Ada é uma artista militante política, consegue ir além das suas atividades como mãe e esposa, mas é valorizada pelo marido pelos atributos de esposa. Margarita consegue ultrapassar a esfera doméstica, entrar na universidade e participar da militância política. No entanto, a militância da jovem é tão distante de sua realidade quanto aquela praticada por Quini.

As outras personagens femininas exercem profissões vinculadas ao lar, como Lurditas, ou à esfera do comércio do prazer, como a prostituta Lina. Portanto, nesse período reforçou-se a ideia de poder masculino sobre o feminino. Posto isso, vale ressaltar que as relações familiares, como o casamento, atendiam aos interesses financeiros, mostrando como o aspecto econômico estava estritamente ligado ao familiar. 


\subsection{Esfera econômica}

A esfera econômica é dominada pelo estado franquista e apresenta dois âmbitos que são representados na narrativa: empregados do estado e meio empresarial. Os funcionários do estado são representados por Prudencio e pelos ministros da Opus Dei. Ambos aparecem na narrativa de modo indireto através de outros personagens e, embora, os ministros não tenham voz ou nomes, exercem influência sobre a vida dos personagens. Acrescenta-se também a polícia franquista e o núcleo operário.

José Ricart protagoniza o contexto empresarial que, diante da instabilidade política, teme pelo futuro de sua empresa. Abaixo de José encontra-se Tomás, o economista na empresa da família, e Julio Ramirez o gerente da Ricartmoble, um homem extremamente eficiente que é visto por Tomás como uma ameaça na disputa pelo poder. Também há o diretor do grupo de empresa Àlvaro Céspedes. Além dos funcionários da empresa de José, destaca-se o advogado Jesús Taboada que atua como uma possibilidade de ponte entre o meio empresarial e o operário. Aqui se acrescenta o mercado de obras de arte protagonizado por Olga e Ada Dutrel. Além disso, existem os profissionais ocasionais, como o estudante Lucas que trabalha em uma loja para pagar os estudos, e algumas personagens femininas se incorporam no mercado de trabalho por necessidades econômicas como Lurditas e Pepa. Outras, como a artista Ada, desejam participar do mercado de trabalho por uma tentativa de reconhecimento social.

A esfera econômica surge como um enredo que contém um mistério sobre a origem da fortuna de José e da história da família Ricart tão questionada por Quini. As respostas revelam-se através dos fragmentos do relato de outros personagens, como Elvira. De acordo com sua perspectiva, a fortuna origina-se em práticas fraudulentas que ocorreram nos primeiros anos do pós-guerra:

Pruden, Tomás, los tiempos habían cambiando. Sus padres - el de ella, el de Tomás, el de Olga- habían tenido otra pasta. Habían sabido nadar y guardar la ropa. Cómo no iban a saber si, si aprendieron a vivir en las trincheras, en las de frente, pero también en la de los despachos, que a veces eran peores, porque bastaba una denuncia, una sospecha que dejaban caer, y ya estabas perdido. El padre de Olga más que el suyo, porque al suyo cualquiera le decía nada, quién le iba a decir traidor, o lo que fuera. Al padre de Olga sí que se lo podían decir, y aún más al suegro, al padre de Tomás, porque esos dos estuvieron primero en un lado y luego en otro. Ellos decían que la guerra les había pillado del otro lado y que se habían pasado en cuanto habían podido, y por supuesto que se habían cambiado de bando, pero más bien 
cuando vieron que lo tenían perdido, cuando estaba claro que la Republica se hundía. Quién sabía lo que habían hecho en el tiempo que estuvieron con los republicanos. Las malas lenguas comentaban que, antes de pasarse - lo hicieran casi al mismo tiempo, aunque no se conocían por entonces, los dos vivían en Valencia, allí los conoció antes de la guerra don Sebastián Barcia -, habían escondido un montón de obras de arte. Unos decían que había sido el padre y otros que había sido el suegro, pero todo el mundo coincidía en que buena parte de esa colección de la que tanto presumía Olga tenía su origen ahí, al margen de lo que vendieron y traficaron; y que de la complicidad durante aquellos años les venía la amistad al padre y al suegro de Olga (CHIRBES, 2000, p.136-137).

Segundo o monólogo interior de Elvira, a fortuna da família Ricart não se originou apenas do empreendedorismo, mas relaciona-se com o contexto da Guerra Civil, visto que José aproveitou-se desse período para traficar obras de arte. A família Ricart mantém-se no ramo e aproveita-se da influência e da fortuna para negociar arte vanguardista. Olga organiza a festa de aniversário de José com o intuito de promover a Fundação de arte mantida pela família Ricart que é coordenada por ela. A festa será apenas um pretexto para expor o quadro comprado por ela e pintado por Ada Dutrel. Além disso, ela acredita que herdará a fundação após a morte de José: “... y, la Fundación, aunque se llamara Fundación Ricart, estaba claro que iba a ser la Fundación Olga Abizu.” (CHIRBES, 2000, p.247).

A confirmação das fraudes em relação à fortuna da família Ricart é apresentada por José Ricart quando relata que Maximino acobertava seus interesses em atividades de contrabando: “...Maxi, que ya había empezado a trabajar como policia, le había propuesto emprender un negocio de estraperlo en el mercado de Legazpi, José le hubiera pedido que fuera su socio... (CHIRBES, 2000, p.54)”. Além disso, José confessa, em uma discussão com Tomás, que os contratos que a empresa fez com o Estado eram comprados:

Pero a ver si es que ahora te crees que la empresa es una fruta nacida en el árbol del mercado libre. No, no nació de la libertad esta empresa. Después, sí; después hemos estado en el mercado, no sé si libre o no, aunque con mucho más apoyos que unos y con un poco menos que otros. Pero eso había sido después. ¿O es que te crees que la contrata exclusiva del mobiliario para todos los ministerios salió de un concurso, o de alguna oposición? ¿Fue resultado de un concurso la contrata con la Dirección de Prisiones para gestionar el trabajo de los presos? La madera quemada, ¿la hemos comprado en libre subasta? Falangistas, jefes del Movimiento, procuradores en Corte. Bah. Abre el abanico de tus relaciones (CHIRBES, 2000, p.22).

A necessidade de mudança é o motivo da discussão entre Tomás e José e também é abordado por Elvira. No trecho "los tiempos habían cambiado" ela alude à mudança do contexto político que refletia no contexto econômico e no comportamento das gerações de 
Tomás e Pruden. Elvira também alude ao contexto ideológico "porque bastaba una denuncia, una sospecha que dejaban caer, y ya estabas perdido". A repressão ocorreu durante toda a ditadura, não apenas na esfera social e política, mas também na esfera econômica, como indicam alguns elementos dos personagens do núcleo econômico do romance, permitindo acompanhar momentos da história econômica ${ }^{18}$ da Espanha após a Guerra Civil.

Vale destacar que os ministros representantes do capital financiero eram integrantes da organização religiosa Opus Dei: "Los años del desarrollo (1960-1973), pilotados por gobiernos con fuerte presencia de ministros del Opus Dei, hicieron de España un país industrial y urbano." (FUSI, 2012, p.233). Nos fragmentos das rememorações de Elvira encontram-se referências às atividades do grupo no final do governo franquista:

Así de claro lo dijo, aunque, últimamente, como Franco había estado chocheando, hubieran empezado a hacerle la cama los del Opus, los camisas blancas...Ambicioso Pruden, claro que sí, pero ella estaba convencida de que Pruden no renegaba de debérselo todo al noventa por ciento a su suegro, o al noventa y cinco si uno se apuraba, porque ahora, por más que se empeñara en que fuesen a misa de doce todos los domingos a la iglesia del Retiro, que era la del Opus, y en peregrinación a la sierra de Rialp, él veía que los negocios se habían puestos correosos, y tanto, porque don Sebastian ya no estaba bajo la capa del cielo, sino por encima de ella, y Pruden tenía que hacer malabarismos para torear tanto lobo con cilicio, porque se habían apoderado de los ministerios económicos... (CHIRBES, 2000, p.135).

...le decía Pruden a Elvira en la soledad del dormitorio, y lo hacía en voz muy baja, como si temiera que hasta allí dentro llegaran los oídos de la Obra (CHIRBES, 2000, p.136).

A Opus Dei representava os interesses sociais da elite que almejava maior liberdade econômica para seu próprio crescimento, mas não desejava a liberdade política. O Plano de Estabilização de Franco permitiu o contato da Espanha com outros países da Europa, modernizando-se não somente a indústria, mas também os valores e os costumes da sociedade. Esse contexto resulta em um descompasso entre a tradição católica e o estado

\footnotetext{
${ }^{18}$ Segundo José Luis García Delgado (1886, p.170-191), a princípio, o regime franquista adotou políticas econômicas baseadas na autarquia e no controle econômico estatal, criando um forte setor público. O sistema autárquico era um modo de repressão, pois o Estado controlava diretamente as atividades de produção e distribuição gerando uma asfixiante burocracia. Como consequência, em 1956 a economia espanhola enfrentava uma grave crise. A inflação, as greves, a perda de poder aquisitivo da população e o isolamento internacional levaram o governo a compreender que não poderia subordinar a economia ao ideal político, pois a sobrevivência do regime franquista dependia da modernização do modelo econômico. No ano de 1959 o governo elabora o Plano de Estabilização, trata-se da incorporação do país no sistema capitalista europeu. Houve certa liberalização da economia, permitindo a entrada de capital estrangeiro que juntamente com estabilização permitiu o desenvolvimento. No entanto, a economia se reestrutura a custa de um sacrifício social, pois há um congelamento de salários desfavorecendo a classe operária. Nota-se mais uma vez o caráter repressor do regime, pois as iniciativas econômicas implicaram em graves consequências para as classes menos favorecidas.
} 
franquista, porém a igreja não perde completamente o poder. Ela impõe seu domínio na economia através dos ministros da Opus Dei. Portanto, a relação entre estado e igreja não se dava apenas na esfera social, mas no econômico. Na construção de Prudencio notam-se traços representativos do estado franquista:

...y es que Pruden no era como los otros hombres. No le gustaba gastar dinero, y, lo que era peor, no le gustaba demostrarles a los demás que lo tenía y lo gastaba. Cuando todo el mundo procuraba lo contrario, o sea, que los demás creyeran que tenía más de lo que tenía, él, al revés: iba y lo escondia. Le sabía mal cambiar de traje, de muebles, de vajilla, dar cenas. Parecía como si aún estuviese en Salamanca con los curas aquellos con los que estuvo interno un montón de años: <<Es que trabajo con el Estado y la gente se fija, y comenta, y no le gusta que, con dinero del Estado, se presuma >>, se justificaba; (CHIRBES, 2000,p.127).

A Pruden le gustaba sorprender el mecanismo por el que el dinero se reproduce; en ese sentido podría decirse que era un pervertido económico, un voyeur, porque, una vez que conseguía ese dinero que había visto brotar, no sabía qué hacer con él (CHIRBES, 2000, p.130).

No fragmento do relato de Elvira, nota-se que o internato católico masculino era uma referência para Prudencio, assim como a Igreja Católica foi referência para a ditadura e ambos são representados a partir da hipocrisia. A esposa o descrevia como alguém avarento e ambicioso; para Olga ele também era mal intencionado: “... y que se excitaba con cualquier cuerpo que cumpliera las expectativas que él alimentaba: soporte econômico.” (CHIRBES, 2000, p.128). Até mesmo as relações pessoais de Prudencio, como a escolha de sua esposa, foram estabelecidas de acordo com as vantagens financeiras que poderiam lhe proporcionar. Ele preocupava-se excessivamente com o dinheiro, mas não acompanhava as mudanças na forma de administrá-lo.

A modernização chegou à Espanha através do Plano de Estabilização que viabilizou a industrialização e instaurou a "tecnocracia". Nesse sistema a tarefa política do governo era transformada em estratégias de desenvolvimento econômico. Os governantes tecnocratas impunham valores políticos, religiosos e conservadores. Aceitavam da modernidade apenas os lucros, mas desprezavam a liberdade e a participação democrática do povo. Segundo Daniel F. A. Espinosa (2003, p.47), a tecnocracia foi utilizada pelo regime de modo tendencioso, como um disfarce para uma forma retrógrada e conservadora de governar. Os valores tradicionais se conservam intactos e se modernizam as estruturas econômicas. No romance, o personagem Tomás é fruto do modelo de comportamento estabelecido pela tecnocracia:

Él se preocupaba de los albañares de entrega de los pedidos y de que éstos llegaran bien a su destino, de las cuentas de resultados de la empresa, del 
estudio de las tendencias del mueble europeo, viajaba a la feria de Milán, cogía un avión a Frankfurt si hacía falta vigilaba los embalajes, respondía a las quejas de los clientes, e intentaba relajarse los fines de semana leyendo revistas de geografía y viajes, y quería comer a gusto cuando llegaba a casa, pero, de un tiempo a esta parte, todo el mundo se empeñaba en que hablase de lo que no le interesaba, y lo empujaban a definirse sobre cosas las que ni tenía ni quería tener criterio... (CHIRBES, 2000, p. 165-166).

Hacía apenas dos horas que había tenido que soportar las recriminaciones de su padre, empeñado en que la muerte de Franco iba a cambiar los métodos de la empresa. Pero que iba a cambiar. ¿Se iba a embalar el género de distinta manera a como se había embalado? ¿Se iba a transportar por otros medios? ¿Iba a llegar de otros países? (CHIRBES, 2000, p.166).

Para Tomás o futuro consistia em manter intacto o presente e esse pensamento serve de suporte para a ordem estabelecida pelo regime, pois ele não desenvolve uma consciência social e sua única preocupação é a produção de móveis da fábrica. Tomás age como um tecnocrata e desfruta do desenvolvimento econômico sem desenvolver consciência crítica sobre o contexto político, é produto dos interesses do regime que se aproveita do desenvolvimento econômico para espalhar o conformismo político e a alienação social, instaurando a desmemoria sobre a relação entre vencidos e vencedores. Na esfera econômica os métodos coercitivos da autarquia são trocados pela persuasão financeira. Sendo assim, os trabalhadores eram inibidos a participar de greves ou reivindicar melhores condições de trabalho. Há descompasso entre as relações econômicas e a formação da consciência política.

Desse modo, a ditadura proporcionou aos empresários certa estabilidade construída sobre a repressão dos direitos dos trabalhadores e da proibição das organizações sindicais. Mas a doença de Franco gera instabilidade no país abrindo espaço para reivindicações dos operários e possíveis transformações: “¿que la empresa atravesaba dificultades por primera vez desde su creación porque todo el mundo estaba asustado, por que Franco se estaba muriendo y la inseguridad se apoderaba de los negocios..." (CHIRBES, 2000, p.17).

Nesse contexto, atuam também os personagens da esfera operária e policial. Lucio e Enrique, como funcionários do metrô, representam a classe dos operários, inclusive aqueles que trabalham para a família Ricart e envolveram-se em greves. A polícia franquista atua para manter o controle social, a "ordem" e a estabilidade do lucro. No romance a tensão gerada pela instabilidade é representada através de José que tenta preparar seus herdeiros para assumirem seu lugar na empresa e adaptarem-se as novas circunstâncias:

Con lo del joven republicano, aludía a que su padre vivía en Valencia cuando se proclamó la Republica, había estado presente en el instante en que izó la bandera tricolor en el ayutamiento y había permanecido en territorio 
republicano al principio de la guerra. Lo había contado muchas veces; que al principio había creído en la Republica y que - eran sus palabras- sólo cuando vio los demanes que cometieron los republicanos se asqueó y se pasó al otro bando y se puso la camisa de la Falange (<<Soy falangista y republicano〉>, se declaraba a veces). Desde entonces, había odiado los partidos políticos ( $<$ La Falange no es un partido $\gg$, , decía), muy especialmente a los anarquistas y comunistas. Por eso resultaba tan extraño que, desde hacía unos meses, hablara de esa manera. Según le había comentado Tomás a su mujer varias veces, el razonamiento de su padre parecía bien hilvanado, pero algo fallaba en su cabeza para permitirse hablar así. <<Me preocupa, está perdiendo la cabeza >>, le había dicho, <<se aferra a ciertas cosas y las convierte en obsesiones. > Don José sacó un pañuelo del bolsillo y se seco la frente. Se había acalorado hablando. Le indignaba que fuera su hijo el único de la empresa que se creía en las estupideces que la radio y la televisión decían. Asociaciones, sí; partidos, no. Átame esa mosca por el rabo. Que todo seguiría igual. ¿En qué cabeza cabía eso? La Falange, el Movimiento, los procuradores en Cortes. Toda esa maquinaria había servido para poner un orden, pero ahora ya no servía para nada. Con eso, se había escrito una partitura con la que había tocado el país su música durante unos cuantos años, pero ahora empezaba otro concierto. El director de orquesta pedía otros instrumentistas para emprenderla con otra partitura. Odiaba a aquellos tipos más de lo que su hijo podía odiarlos. (CHIRBES, 2000, p. 24).

José indigna-se sobre o fato de que Tomás negava-se a aceitar a possibilidade de mudanças econômicas. Ele é caracterizado como alguém distante da realidade que acreditava nas notícias da imprensa franquista: "el único de la empresa que se creía en las estupideces que la radio y la televisión decían”. Através da mescla das perspectivas de Tomás, de José e do narrador desenha-se um panorama das expectativas econômicas em relação ao futuro.

Como se observa no trecho citado, após a discussão calorosa, a perspectiva é sutilmente transferida de Tomás para José com a mediação do narrador onisciente. A mobilidade de perspectiva entre o narrador onisciente e o monólogo interior indireto de José e Tomás não é visível a partir de uma leitura superficial, pois é necessário analisar o plano semântico e sintático. No plano semântico fica evidente que Tomás desconhece as verdadeiras intenções do pai em relação aos partidos políticos, pois acredita que José abandonou o grupo republicano pelas injustiças que cometiam, mas, na realidade ele encontrou nos falangistas uma oportunidade de enriquecer. Contudo, José expressa claramente seu ódio pelos republicanos na última frase: "Odiaba a aquellos tipos más de lo que su hijo podía odiarlos." Mesmo assim, planeja reaproximar-se do partido porque a nova organização política e econômica do país exigia essa mobilidade.

No plano sintático, o narrador utiliza a mescla de perspectivas para se camuflar, pois em um único parágrafo a perspectiva do narrador transita entre Tomás e José com a finalidade de contrastar seus pontos de vista. O momento de transição de perspectiva não se expressa pela 
tipografia ou pontuação, mas pelo tempo verbal empregado. No início do fragmento, quando o narrador onisciente acompanha Tomás, os verbos estão no pretérito imperfeito (aludía, resultaba, parecía, fallaba, indignaba), pretérito perfeito do indicativo (proclamó, izó, vio, cometieron, asqueó, pasó, puso, sacó, secó) ou pretérito mais que perfeito composto (había estado, había permanecido, había contado, había creído, había odiado, había comentado, había indignado). No momento de transição o verbo "átame" é empregado no presente, revelando um desdobramento do tempo interno da consciência para o tempo objetivo e a mudança de perspectiva de Tomás para José: “Asociaciones, sí; partidos, no. Átame esa mosca por el rabo [...] La Falange, el Movimiento, los procuradores en Cortes. Toda esa maquinaria había servido para poner un orden, pero ahora ya no servía para nada."

Em seguida, os verbos voltam para o pretérito e a perspectiva narrativa acompanha os pensamentos de José. Os momentos de transição apresentam ambiguidade, pois são acompanhados de características singulares como associação de ideias e construção de imagens que podem defini-los como narração onisciente ou um monólogo do personagem. A sintaxe das frases não é convencional, pois sua organização difere do padrão sujeito-verboobjeto e baseia-se na associação de ideias representada por uma sequência de substantivos, expressões idiomáticas e interpelações. A sequência de substantivos (Asociaciones, partidos, Falange, Movimiento, los procuradores en Cortes) sugere uma construção imagética do franquismo e a organização dos elementos na sintaxe atribui um ritmo acelerado para a leitura deste trecho, de forma que o leitor compartilhe o sentimento de indignação de José. O verbo no pretérito e o conector "con eso" sinaliza o fim do monólogo interior ou interpelação do narrador e indica a total imersão na perspectiva de José, pois o discurso torna-se articulado e organizado, inclusive, recorre ao uso de metáfora para comparar o momento político com a mudança de músicas em uma orquestra.

Diante do contexto, para os empresários, os acordos com os trabalhadores são mais necessários do que uma política de trabalho opressiva. Ricart percebe que é preciso negociar com os trabalhadores para uma solução pacífica dos conflitos. José começa a desconfiar de um sistema cuja eficácia é cada vez menor, pois aumentam as greves. Desse modo ele recorre ao funcionário Julio Ramirez para convencer seu filho da necessidade de mudança:

'Yo creo que usted tiene razón y, en estos momentos, nada podría convenirle más a la empresa que una ampliación de capital en la que se diera participación a los trabajadores, siguiendo algún método que tuviese en cuenta varios parámetros: su dedicación, su tiempo de permanencia en la casa, en fin, cosas así. Incluso convendría que, en pocos meses, ustedes quedaran apenas aparentemente en minoría en el seno de esa sociedad; claro 
que, ya digo, sólo aparentemente, porque se pueden cruzar una serie de hombres de paja que ostenten las participaciones a título sólo nominal y que las devolverán en cuanto los tiempos se normalicen. He hablado con Taboada, y está dispuesto a participar a cambio de alguna compensación económica. Ellos necesitan como agua el dinero para organizarse. Tienen que jugar fuerte si quieren ir desbancando a los comunistas en los sindicatos' (CHIRBES, 2000, p.21-22).

Taboada participou de movimentos contra a burguesia espanhola, mas foi preso e dedicou-se a organizar uma célula política que promove atentados contra a ditadura. No entanto, ele desiste da luta revolucionária quando percebe que terá vantagens econômicas se atuar em favor da burguesia. Sendo assim, ele representa essa possibilidade de negociação desejada por José, pois ele se comporta de modo flexível diante das adversidades, adaptandose ao contexto político e econômico. Trata-se de um oportunista, pois se aproveita do movimento operário para atuar como um mediador entre empresários e trabalhadores com a finalidade de ascender socialmente: “ $<<$ No es um fanático Taboada. Usa el fanatismo para sus propios fines $>>$, le había dicho Julio.” (CHIRBES, 2000, p.25). Para José, Taboada é o oposto de seu filho Tomás, um homem capaz de mover-se dentro dos estratos sociais e conquistar seu espaço: “...y algunas noches, mientras pensaba acerca del futuro de sus empresas cuándo él ya no estuviera, había llegado a querer que su hijo fuera él, Taboada, en vez de Tomás." (CHIRBES, 2000, p.25). Ironicamente a voz de Taboada é recuperada ao ser evocada por outros personagens através de referências e rememorações como uma possibilidade de adaptação às transformações do futuro e como mediação com a classe operária: "A la clase obrera hay que putearla, cercala, cerrarle el camino de vuelta atrás. Convercerla de que es carne de cañón de verdad, de que no vale nada, para que salte y muerda." (CHIRBES, 2000, p. 152).

Para o advogado Jesús Taboada o futuro resume-se a uma questão de adaptação às novas condições. Ele se movimenta entre os dois lados ideológicos de acordo com suas necessidades. Desse modo, aproveita-se do clima de instabilidade política da Espanha e, numa manobra política troca de lado: abandona a célula em que militava, deixa de defender os processos de interesse dos trabalhadores e associa-se a um grupo de advogados que defende os interesses econômicos de grandes empresários. Usando de sua hipocrisia e capacidade de manipulação o advogado justifica sua ação:

Marx nunca buscó hacer felices a ese ejército de brutos a los que defendió. Buscó ser coherente con su pensamiento. Cogió un hilo, tiró de él, y devanó la madeja hasta el final. Esto es todo. El sentimentalismo lo habéis puesto 
vosotros, los revisionistas, y muchos de estos de aquí abajo, de esta galería, maoístas, ex curas de la oerreté y gente así (CHIRBES, 2000, p. 152).

O narrador apresenta total distanciamento de Taboada, pois ele surge na narrativa somente através das memórias e breves referências de outros personagens. Isso não significa que o personagem possua menor grau de importância para a história, mas revela que o narrador onisciente é tão ativo na obra quanto os personagens e não compartilha da opinião de Taboada. Pode-se dizer que a há uma repulsa em relação ao comportamento do advogado.

A partir da análise do confronto de vozes aglutinadas no núcleo econômico, pode-se afirmar que a relação entre vencedor e vencido transforma-se na relação entre explorador explorado.

\subsection{Esfera Cultural}

O desenvolvimento da economia não acompanhou o desenvolvimento de nível cultural. No entanto, houve exceções, pois a industrialização e a abertura da Espanha facilitaram a busca por cultura e consciência crítica. A cultura e a educação foram veículos ideológicos da ditadura que permeavam todas as classes sociais com a finalidade de colocar fim aos ideais liberais propiciados pela Segunda República (1931-1936). O romance capta a função doutrinadora dos agentes da esfera cultural: artistas, professores, livros, teatro, música, cinema e rádio. Submetidos ao controle da censura, isolam a sociedade do contato com o exterior, com a cultura produzida, por exemplo, pelos exilados republicanos. Durante décadas garantiu-se o predomínio de valores católicos, mas com o desenvolvimento econômico surgiram focos de protesto em diversos setores da sociedade e, principalmente, na universidade: "La década del desarrollo vio, como contrapartida, la reaparición de la conflictividad. Los estudiantes e intelectuales se rebelaron en demanda de libertades y derechos democráticos.” (FUSI, 2012, p.235).

A esfera cultural está divida em dois aspectos: a cultura de minorias e a cultura de massa. O regime estimulou a criação artística para a grande massa social com a finalidade de alienar as pessoas, como se observa na vida de Olga, Carmen e Elvira. A cultura de minorias está representada em personagens do núcleo universitário, nos hábitos de Ada e Olga e na militância clandestina com Taboada e Lucio. Durante o regime franquista a educação esteve sob a responsabilidade da igreja católica. No romance a dominação católica é representada 
pelos argumentos religiosos que os alunos usam para convencer o reitor a permitir um encontro literário:

El decano lógicamente, negó su autorización, convencido de que la convocatoria era sólo una excusa para reunir subrepticiamente un mitin para agitar la facultad, en los difíciles momentos de la agonía de Franco, por más que los alumnos no vacilaran en remontarse a ejemplos evangélicos: Juan Evangelista, o el Mesías, hombres que mueren para redimir la humanidad, y yendo aún más lejos, le mostraron ejemplos del Antiguo Testamento: diversos profetas, el proprio Moisés subiendo a solas al monte Sinaí, y recogiendo las tablas de la ley, y encontrándose al bajar a toda aquella multitud que bailaba adorando al becerro de oro, bebía y fornicaba, y, preso de rabia, rompiendo contra el suelo las tablas de la ley, porque se sentía defraudado, traicionado, asqueado al contemplar la fragilidad humana; [...] Como era de suponer, el decano tampoco se creyó ni una palabra de su frágil y rebuscada exposición de motivos, y reiteró su negativa a la celebración del acto: <<Eso es un mitin subversivo>> ... (CHIRBES, 2000, p.95-96).

No romance, a universidade é caracterizada como um dos poucos espaços de liberdade. Apesar dos riscos, os alunos promovem o debate, buscam a liberdade de expressão e tentam negociar com as autoridades acadêmicas. As atividades do sarau literário possuíam como objetivo expor as aspirações dos alunos para o futuro e despertar a necessidade de novas pautas a serem discutidas. No entanto, o reitor não permite a realização do sarau e o caracteriza como um mitín subversivo. Durante o franquismo as atividades culturais evocavam as Missões Pedagógicas ${ }^{19}$, que haviam sido um poderoso instrumento de luta popular, pois pressupunham participação ativa de diversos setores da sociedade, como estudantes, artistas e trabalhadores. Desse modo, foram consideradas pelo regime como atividade subversiva.

No topo da hierarquia representada pela cultura de minoria está o reitor, pois todas as atividades da universidade dependem de sua autorização. Abaixo desta posição de autoridade, encontram-se os professores divididos entre os católicos, ligados à tradição orteguiana, e professores marxistas, como Juan Bartos:

\footnotetext{
${ }^{19}$ Trata-se de um projeto cultural patrocinado pelo Governo da Segunda Republica Espanhola. O objetivo do projeto era promover o desenvolvimento cultural (música, cinema, teatro, obras de arte) e a alfabetização no interior da Espanha. De acordo com Francisco J. Romero Salvadó (2008, p.57): "Na verdade, uma das realizações republicanas mais louváveis foi o compromisso com a educação pública [...] o Ministério da Educação criou empreendimentos culturais como as chamadas Missões Pedagógicas ou companhias teatrais como La Barraca, de García Lorca. Esses missionários modernos eram as tropas de choque a liderar uma nova era igualitária que substituiria o catolicismo - até então motor ideológico da hierarquia social - pelo humanismo secular e pela justiça social. Eles viajavam para cidades remotas e pequenos vilarejos onde exibiam filmes, liam poesias e ensinavam princípios democratas. Quando partiam, deixavam uma biblioteca com os clássicos da literatura."
} 
Era uno de los temas predilectos del profesor Bartos, que había pedido una beca para estudiar filosofia alemana en Minuch y, mientras llegaba, impartía lecciones en las que hablaba mucho de Hegel, Marx, Benjamin, Marcuse y Adorno. Su empeño era aprender alemán en Alemania, y guardaba sus mayores dosis de odio para Ortega y los orteguianos, Zuburi y la ralea jesuítica que lo rodeaba (CHIRBES, 2000, p.91).

O narrador apresenta os autores lidos pelos personagens com a finalidade de apresentar a ideologia e o ponto de vista de cada um. Bartos lê as obras de Hegel, Benjamin, Marcuse, Marx e Adorno. Essas leituras conduzem suas aulas, vistas como um espaço de liberdade em que era possível abordar questões como, a democracia e o estado de exceção. O professor também faz referências aos adversários dos intelectuais de esquerda. Ele apresenta aos alunos uma vertente católica representada por Ortega (1883-1955) e Zubiri (1898-1983), filósofos espanhóis que atuavam em favor do regime, e ressalta o papel da Igreja no processo de consolidação de uma educação que inibia o desenvolvimento do senso crítico. Através desses filósofos coloca-se o debate da arte não comprometida.

O início da reabertura política é marcado pelo retorno de alguns dos exilados, como o professor Chacón que se depara com uma nova Espanha, aludindo ao escritor Max Aub $(1903-1972)^{20}$. Sua atuação no romance indica que o exílio é um modo de anulação e de esquecimento, pois, mesmo após o retorno a Espanha não encontra um lugar. Por isso, Chacón isola-se até mesmo dos marxistas que ansiavam por seu retorno. Devido a essa perspectiva negativa da sociedade espanhola, Bartos e Chacón entram em conflito:

El viejo profesor no había entendido los cambios de mentalidad que se habían producido en el país durante su ausencia y esa incapacidad para entenderlos y para adaptarse a ellos le había agriado el carácter. Se lo había expresado con franqueza y con un punto de ingenuidad a Juan al poco tiempo de llegar: <<Yo creía que España se había paralizado a la espera de que volveríamos, que todo seguía igual, con un vacío en algún lugar que nosotros llenaríamos, pero no, no es así. España ha cambiado, ya no es nuestra, es de ellos. Quién crees tú que puede. Hay una juventud, una juventud que han formado ellos, que es parte de ellos aunque se les oponga. Son los anticuerpos que ellos mismos han creado para salvarse cuando enfermen de verdad, la vacuna para que él país siga siendo suyo. Esta

\footnotetext{
${ }^{20}$ A alusão a Max Aub é uma peça-chave para a narrativa, pois ele representa um porta-voz da memória espanhola republicana. Sobre esse assunto tomamos as palavras de Gérard Malgat (2011, p.1): "No se trata aquí de hacer una apología de este escritor o la exégesis de su obra, sino de poner en evidencia de qué manera su trabajo de escritura y más ampliamente su compromiso de <<periodista-alumbrador >>, como él mismo se definía, han aportado una pieza indispensable a la constitución de una memoria histórica. No solo para España, sino también para Francia y México, país de acogida de este <<parisiense indesiráble〉> que se convirtió en escritor español y ciudadano mexicano debido a los seísmos de las guerras mundiales”. Além disso, Max Aub escreveu a obra "La Gallina Ciega" (1995), trata-se de um diário que apresenta reflexões e impressões provocadas após trinta anos de exílio no México em que ele ressalta a necessidade de recuperar a memória e denuncia a passividade e a aceitação do controle político-social.
} 
España de ellos no me interesa para nada. Que se la queden y les aproveche >> (CHIRES, 2000, p.186).

Bartos critica Chacón por isolar-se socialmente: “En cuanto me explique desde un punto de vista marxista eso de que no hace falta salir de casa para aprender, le prometo que no vuelvo a molestarle con mi insistencia'." (CHIRBES, 2000, p.188). Por um lado, Bartos entra em conflito com o professor porque ele decide enclausurar-se com seus livros num processo de isolamento intelectual e social; por outro lado, Bartos representa um professor jovem com outra mentalidade e também se recusa participar de manifestações populares, reservando sua militância aos livros e às aulas na universidade:

A él no le gustaba demasiado aquel ajetreo revolucionario en el que estaba metida su mujer, cuyo ideario, por otra parte, compartía; no le gustaba las reuniones ni los comandos y manifestaciones, como no le gustaban los espectáculos masivos - conciertos, recitales-, y ni siquiera la práctica de los deportes, con su brusquedad; era más bien sedentario (CHIRBES, 2000, p. 199).

Bartos e Chacón representam o grupo dos docentes antifranquistas: Chacón está entre aqueles que perderam seu lugar, sofreram com a violência do exílio e encontram-se desmotivados e sem esperanças. Bartos, pertence à universidade, recebe um baixo salário e empenha-se em driblar o regime ao emprestar sua sala para os alunos debaterem temas proibidos pela censura. Orientado por ele, o grupo de estudo dos alunos tenta suprir a ausência das ciências sociais durante a ditadura e interpretar a realidade. Trata-se de um processo de elaboração cultural clandestino através das leituras de obras de Karl Marx.

$\mathrm{Na}$ base da hierarquia encontram-se Quini, Margarita, Lucas e Pedro. Os alunos de Bartos representam a geração à qual Chacón se refere com pessimismo e denomina de herdeiros do franquismo. Embora, Bartos os defina desse modo, eles representam uma minoria intelectual disposta a discutir os " $<<$ Cambios en el poder y revolución de las formas $>>$ " (CHIRBES, 2000,p.90). No grupo de estudo, todos ganham voz e há uma mistura social que destoa da rígida hierarquia imposta pelo regime. Embora, professores e alunos apresentem um caráter anticapitalista e revolucionário, eles expressam uma multiplicidade de formas de militância e de concepções do marxismo. A diversidade é interpretada por Bartos:

Juan Bartos no le recriminaba nada a nadie, ni siquiera le gustaba el victimismo obrerista cuyo lenguaje tan de moda estaba. Creía que cada hombre estaba obligado a extraer el mayor número de ventajas de los atributos que la naturaleza le había otorgado. Él régimen imponía ya suficientes limitaciones al desarrollo de la inteligencia como para que uno 
las aumentara con dosis de victimismo, que a veces lo único que hacían era disimular la pereza mental (CHIRBES, 2000, p.192).

No romance, os primeiros ares da universidade, como um espaço para o debate e divergências de opinião, estão na atuação dos personagens estudantes. Os alunos são membros de uma geração jovem que viveu o desenvolvimento econômico, nasceram três décadas depois da Guerra Civil, não viveram os anos de racionamento, estudam e não aceitam tão facilmente os valores transmitidos pelos pais. Eles dispõem de fontes de informação distintas do ambiente familiar que refletem outros modos de vida. Vale ressaltar que entre eles circulam livros clandestinos, que os colocam em contato com outras ideias, e procuram aproximarem-se do movimento dos trabalhadores para ganhar força na luta contra o regime.

Pedro Macías e Lucas Álvarez participavam do movimento operário. Eles aproximamse da classe trabalhadora e identificam-se com o movimento, pois eram alunos socialmente desfavorecidos que trabalham como operários e vivem na periferia da cidade. Em parte, o “victimismo obrerista” criticado por Bartos está representado em Lucas que atribui o amor não correspondido de Margarita à sua classe social. Ela e Quini são referências de um estrato social superior e Lucas, ao deparar-se com esse distanciamento de classe, questiona sua própria capacidade de ser sujeito histórico. Desse modo, ele vive um complexo de inferioridade, devido a seu lugar no triângulo amoroso. Margarita era alvo do amor de Lucas, mas estava apaixonada por Quini:

... y ella se presentaba en la facultad tres semanas más tarde con el volumen de La centena en la mano, y, acabadas las clases, se sentaba en el autobús sosteniendo junto al pecho, rozándolo con el pecho. Lucas veía el libro allí, en su mano tibia, contra sus pechos tibios, y sufría, porque él ya se había leído La centena antes que el proprio Quini, pero sabía que ella no iba a hablar de ese libro con él (CHIRBES, 2000, p.112).

O narrador não apresenta outras leituras realizadas por Margarita porque sua motivação no grupo de estudos não estava relacionada com a militância, mas com a presença de Quini e, sobretudo, do professor Bartos, alvo de seu desejo. A descrição do narrador e a representação de sua consciência revelam que ela tinha conhecimento do contexto histórico, mas não desenvolveu capacidade de refletir criticamente. Margarita mantém o modelo do planejamento educativo dirigido às mulheres durante o regime franquista que a subordina ao homem e lhe reserva apenas funções domésticas. Como já foi observado no primeiro capítulo dessa dissertação, Margarita foi educada para casar-se e dedicar-se ao lar; no entanto, mesmo 
tendo acesso à cultura e à universidade não relaciona seu contexto privado com o contexto político.

O triângulo amoroso entre Pedro, Margarita e Quini coloca em evidencia o conflito de classes. Para Lucas a diferença de classe social é um obstáculo amoroso, pois não se sente à altura do personagem e tem ciúmes quando descobre que Margarita lê aquilo que interessa a Quini. As observações de Lucas sobre esse tema sugerem que a cultura também estava presa ao estrato social, pois era dominada por aqueles que possuíam maior poder aquisitivo:

Qué podía esperar Margarita de Lucas, hijo de un albañil viudo, estudiante que trabajaba por horas en los repartos de la cristalería. Margarita acudía con abono familiar a los conciertos del Real y conocía a sus veintipocos años Roma, París, Londres y Amsterdan, y hablaba algo de alemán (<<estuve un verano estudiando en Munich $>$ ), un correcto inglés en que tarareaba las canciones de Dylan y de los Rolling Stones (<<lo aprendí en un intercambio con una familia de Edimburgo $>)$, citaba a Baudelaire en francés $(<<L a$ Maladie et la Mort font des cendres/ De tout le feu qui pour nous flamboya $>$ )... (CHIRBES, 2000, p. 114, grifo do autor).

As interpelações do narrador ressaltam as viagens realizadas por Margarita, nas quais ela adquiriu novas concepções de cultura em todos os aspectos, inclusive aprendeu novas línguas. A diferença social entre os personagens também está marcada pelo repertório de leituras, pois Lucas e Pedro recorrem a autores que se identificam com o movimento operário:

...hacían más hincapié en el origen de la obra como fruto del trabajo materialismo: mano y cerebro - y estaban de acuerdo con Iliá Ehrenburg cuando afirmaba que <<el arte nuevo dejará de ser arte〉>, expresado en el sentido de que un poema o un cuadro no eran nunca una aparición, sino una obra difícil, como el trabajo de un obrero, y que, como el trabajo de un obrero tenían que tener función (CHIRBES, 2000, p.93).

Desse modo, o narrador sugere que o acesso à cultura, à educação, às viagens e ao conforto proporcionado à jovem eram financiados pelos pais. O mesmo processo é vivenciado por Quini. Ele busca preencher as lacunas deixadas pelo pai e pelo avô através da militância e das leituras de Karl Marx, León Trotski e Guy Debord. Seu repertório cultural o caracteriza como um militante burguês, pois diante da situação do país torna-se irônico o interesse de Quini por um filósofo que defende a revolução por meio da estética como Guy Debord. Embora, as leituras de Marx e Trotski proponham um discurso libertador em defesa da classe operária, não há, no seu caso, coerência entre teoria e prática:

...ni él quería a los empleados de las fabricas, ni los empleados lo querían a él, que defendía que la propiedad de la empresa fuera de ellos. Quería hacerlos dueños de su destino, pero no le gustaban (CHIRBES, 2000, p. 287). 
Quini e Margaratira são herdeiros de famílias franquistas, mas militam contra a ditadura. $\mathrm{O}$ avô de Margarita era colaborador direto na ditadura de Franco e o avô de Quini enriqueceu roubando obras de arte e aliando-se ao lado falangista durante a guerra. Eles configuram a segunda geração nas famílias franquistas, geração que não viveu diretamente o trauma da Guerra Civil e consideram o franquismo como um obstáculo para a vida acadêmica e social que atua contra eles mediante a repressão. Quini vive uma relação conflituosa com o pai devido à sua posição ideológica, pois para ele o pai era um inimigo, um membro da classe opressora adversa aos seus ideais marxistas. Ele questionava o pai sobre o controle de capital exercido pela empresa da família e sugeria que a produção deveria ser controlada pelos trabalhadores. Para defender-se dos argumentos de Quini, Tomás ressalta que a cultura do filho provém de seu poder aquisitivo, do dinheiro da família:

¿No has viajado a Londres, a Amsterdan, a París? ¿No ha sido así? ¿Y me
estás diciendo que vas a decidir no ganar lo suficiente para ir a Estambul?
¿Quién va a decidir que tú no puedes ir a Estambul, porque tiene que ir otro
que lo merece más que tú? ¿En nombre de qué o de quien te van a privar tus
viajes, leas u oigas esa música que tanto te gusta? Pues eso es dinero. El
dinero es el libro que te lees, y la salud en parte es dinero, el hospital, la
prótesis que has llevado en los dientes para corregírtelos, eso es también
dinero, y del amor, no me hables (CHIRBES, 2000, p.176).

Tomás é um herdeiro da ditadura franquista e não avalia de forma crítica o momento histórico. Quini representa as expectativas depositadas na transição, pois anseia pela democracia e defende uma ideologia revolucionária. $\mathrm{O}$ acesso à universidade permite que o jovem entre em contato com teorias e filósofos que possibilitam a construção de sua visão de mundo. No entanto, seus estudos eram financiados por uma família de empresários falangistas. Vale ressaltar que o mesmo processo ocorre com Margarita, pois a vida independente e luxuosa, assim como o discurso libertador da jovem, era financiada por pais adeptos ao regime franquista.

Ao mapear as relações que os personagens estabelecem com a cultura evidencia-se como ela se configurou como veículo ideológico e de doutrinamento do regime. Além disso, destaca-se sua relação com as classes sociais. Há um contraponto entre aqueles interessados em alcançar acesso a ela, como Lucas, Pedro e Lucio, e aqueles interessados em continuar usando-a como instrumento de domínio, como Ada e Taboada.

O repertório de Lucio, membro da célula revolucionária e trabalhador do metrô, é composto por "libritos de papel amarillento, usados y pagojosos, que hablaban de revolución, comunismo, facismo,proletariado y luchas de clases..." (CHIRBES, 2000, p.88). Nota-se que 
a literatura utilizada por Lucio consistia em propaganda anônima e contrasta com os intelectuais de esquerda, como Bartos, Quini e Taboada que leem diretamente os autores. Tal contraste representa o complexo universo dos repertórios ideológicos das forças de progressistas $^{21}$. Taboada aproveita-se da apropriação dessas ideologias para justificar sua saída do Vanguardia Revolucioria e manipular Lucio:

$<<$ Lucio, no se trata de ser mejor o peor. La revolución no se hace con buenas intenciones >>, le decía Taboada. Y cuándo él le hablaba de compañerismo, de compasión, de piedad, hasta de misericordia ante las injusticias, Taboada se burlaba. Y a él esa dureza le jodía, pero también lo atraía. Tenía un brillo de verdad desnuda, sin adornos. Pensaba Lucio que los adornos era los que encubrían el hecho de que todos aquellos obreros vestidos de azul que en las asambleas habían dicho sí huelga, todos unidos hasta el final, ahora estuvieran vendiendo billetes tras las ventanillas, abriendo puertas, cavando en los túneles, conduciendo trenes (CHIRBES, 2000, p.150).

Lucio também desconfia da cultura e a confunde com os "adornos" aos quais Taboada recorreu para convencê-lo a entrar no Vanguardia e a militar com práticas de luta armada. Ele também se refere à hipocrisia dos outros operários que desistiram da militância e voltaram ao trabalho.

São esses personagens de classes sociais diferentes que comentam o processo de construção da memória coletiva da Espanha e do esquecimento. $\mathrm{O}$ advogado considera a possibilidade de narrar a história de outro modo, suprimir e reconfigurar os protagonistas ou a ação. Ele explicita o processo de silenciamento quando afirma que a escritura da história pertence às classes mais abastadas, isto é, aqueles considerados vencedores pela história.

Lo que no quede escrito, no habrá existido, y lo que ha existido lo escribirán ellos a medida. Así que ya sabes, dentro de unos anos no habréis existido. Tu pasado me lo inventaré yo a la medida de mis necesidades. Tu lucha será una medalla que me pondré en mi solapa [...] Tú y los de la clase habéis trabajado para que yo tenga un pasado. Con el tiempo seréis un ejército de hormigas sobre la superficie de la luna. ¿Has visto esos cuadros de tu ex camarada Genovés? ¿Esas multitudes que son solo puntos negros que parecen que corren en determinada dirección o que se dispersan? (CHIRBES, 2000, p. 155).

No trecho citado, há uma referência ao quadro "Punto de Mira II, 1966" de Juan Genovés $^{22}$ que mostra uma massa humana vista do alto, como um formigueiro. O quadro é uma metáfora para os esquecidos pela história, como Lucio, representante da classe operária: “...cuando ya no formamos parte del grupo en cuya memoria se conservaba tal recuerdo,

\footnotetext{
${ }^{21}$ Sabini Schimitz (2006) realiza uma análise minuciosa da rede intertextual presente na narrativa.

${ }^{22}$ Juan Genovés Candel nasceu em 31 de maio de 1930, é um pintor e artista plástico espanhol.
} 
nuestra propia memoria se debilita por falta de apoyos exteriores" (RICOEUR, 2003, p.159). Através das rememorações das conversas de Lucio com Taboada, o romance questiona o processo de escritura da história. O personagem Lucio expressa o desejo de participar do processo de construção da história, mas é silenciado, não só através da repressão violenta, mas também pelos intelectuais que dominam a cultura:

Te subes en un bidón y en el metro, y dices: <<Compañeros, no nos dejan hablar, esto es injusto>>; pero imagínate que te dejaran hablar, ¿qué dirías? Nada. Ese día, si es que llega alguna vez, en que dejen hablar a todo el mundo, hablarán los que saben. ¿Qué sabes tú de Lenin? Nada. Ese día hablarán los especialistas en Lenin, y ya no será Franco el que te callará. Serán ellos (CHIRBES, 2000, p.153).

Assim como Jesús Taboada, Ada também domina a cultura e a utiliza a seu favor, pois está entre os artistas que buscavam reorganizar-se para traçar os novos caminhos que a abertura política permitiria. Trata-se de uma época em que uma aparente liberdade surge lentamente:

...había aparecido citado el nombre de Ada entre los artistas más jóvenes que buscaban un arte comprometido en los resquicios que dejaba la omnipresente censura franquista (CHIRBES, 2000, p.194-195).

En las reuniones a las que ella asistía, y en las que Juan casi nunca quería estar presente, se hablaba de la necesidad de formar a la muerte de Franco un gobierno en la sombra en el que estuvieran incluidos todos los partidos democráticos, el embrión de lo que sería el primer gobierno libre de España en casi medio siglo, y que se encargaría de dar el salto político desde la dictadura a la democracia: un gran pacto de todas las fuerzas del trabajo y la cultura (CHIRBES, 2000, p.204).

O narrador descreve minuciosamente uma ilustração intitulada "Abecedario" que ela preparou para a Revista Ruedo Ibérico. Ela presenteia essa obra ao "pecé" com a intenção de que represente um "recordatório de un tiempo que, para entonces, ya se habrá extinguido; recordatorio para los mayores y advertencia para los jóvenes.” (CHIRBES, 2000, p.198). Esse trabalho artístico de Ada revela suas contradições, pois ela expressa seu desejo de romper com o contexto político em que estava inserida através da elaboração de um dicionário que é uma forma congelada. A artista sabe que sua obra conta com todos os requisitos para tornar-se uma referência no mercado de arte após a morte de Franco, por isso via a transição com esperança e com a possibilidade de uma nova oportunidade profissional. Ela julgava que após a reabertura política a atividade intelectual espanhola se reorganizaria com o objetivo de encontrar nomes respeitados para a reorganização de uma sociedade cultural decapitada. Vale 
destacar que seu êxito, assim como o de Olga, deve-se à ligação de sua família com o regime militar:

Tampoco se había atrevido a confesarse Ada que si la exposición no había tenido problemas con la censura había sido por sus relaciones con López Rodó, amigo intimo de su padre y ex consejero de la metalurgia que la familia Dutruel poseía en Basauri. A Navarro, el represente de los artistas plásticos del pecé, Ada le aseguró que, dentro de un tiempo, iba incluso a regalarles los derechos de tirada en fotomecánica, con lo que podrían hacer una serie de pósters para la venta, siempre que se destinaran los beneficios a financiar las actividades artísticas de miembros del partido (CHIRBES, 2000, p.198).

Ada é uma artista importante para a vanguarda espanhola, através da militância constrói sua carreira e livra-se da censura por pertencer a uma família poderosa. Além disso, o personagem busca na arte de vanguarda um movimento de ruptura com o passado, um anseio por uma nova organização cultural e social. Consciente da importância da arte nesse contexto, Ada deseja participar do novo contexto artístico. Ironicamente, Olga é a principal compradora dos quadros de Ada, inclusive pretende presentear o sogro, em seu aniversário, com uma de suas obras. Por isso, Ada e seu marido, o professor Bartos, são convidados de honra para a festa de aniversário.

A censura se apropriou da cultura de minorias com a finalidade política de apagar as práticas democráticas do passado, exaltar a hierarquia e inibir o pensamento crítico. Desse modo, o regime estimulou com subsídios a produção intelectual para a cultura de massa, em que o amor romantizado e o herói eram o assunto para uma Espanha nacional católica. Essa cultura carente de preocupações políticas possuía grande popularidade e favorecia a relação alienada com a sociedade. No romance esse âmbito está representado, sobretudo, no repertório cultural das personagens femininas, pois o amor foi temática de uma Espanha devastada.

A cultura de massas é representada por meio de Olga, Carmem e Elvira. As personagens conservam um gosto peculiar de filmes e textos que veiculavam o idealismo romântico, a virtude de castidade, a obediência. Segundo Valéria De Marco (2000, p.252), anarquistas e falangistas disputavam e apropriaram-se do modelo da "novela rosa" para difundir suas ideias: por um lado, os anarquistas abordavam a temática da liberdade individual, solidariedade e igualdade entre homens e mulheres; por outro lado, os falangistas representavam uma mulher submissa e dedicada apenas na esfera doméstica:

A espanhola genuína e católica, submissa ao pai, ao marido ou ao governo, está disposta a todo sacrifício para o bem da família, tem força e alegria para 
vencer os inimigos, sejam eles a pobreza, a luxúaria anarquista, as tentações do consumo norte-americano ou a conversa daquela perigosa associação entre judeus, intelectuais e comunistas. (DE MARCO, 2000, p. 252).

Os apontamentos que o narrador faz sobre as leituras das personagens femininas indicam características da "novela rosa" falangista, pois exploraram a temática do comportamento da mulher, do casamento e do lar. Dentre as atividades de lazer de Olga, Elvira e Carmem, estavam narrativas relacionadas a esse modelo falangista que orientava o comportamento das mulheres. Elvira justifica seu casamento frustrado, do ponto de vista amoroso, com as ideias apresentadas nos romances de folhetim: "En todo caso, se decidió por mi dinero, y no por el tuyo' - le respondió Elvira con las palabras que usaba la protagonista de un viejo folletín que había leído mucho tiempo atrás.” (2000, p.128).

Carmem não associa Arroyo às atrocidades do regime político e rememora sua chegada ao vilarejo a partir de uma perspectiva romântica. Ela se refere a histórias de amor e personagens de filmes, como Gary Cooper, Douglas Fairbanks, Clark Gable. Trata-se de uma produção cultural que retrata um mundo feliz, sem problemas sociais que propaga a ideia do amor romântico e reforça o papel submisso da mulher relegada ao espaço doméstico:

Durante años había soñado en sus noches de adolescente con eso, con querer a alguien. Se había contado las amigas en la escuela las películas que ponían en los cines de la capital o de las pequeñas ciudades, a las que habían ido por alguna razón -médicos, papeleos - y en las que habían tenido ocasión de ver alguna cinta mientras hacían tiempo para coger el autobús de regreso a Riaño. Gary Cooper, Douglas Fairbanks, Clark Gable: ellos las cogían en brazos, las besaban, las querían; ellas llevaban hermosos vestidos, y tenían rostros de porcelana y pestañas largas y curvas. Aquellas muchachas habían soñado durante años en que apariciera en el estrecho horizonte de la casa cuartel en la que vivían algún hombre que se pareciera a los que habían visto en el cine, y una mañana bajó de un automóvil Maximino... (CHIRBES, 2000, p.296).

Olga recorre a leituras sobre o comportamento feminino para definir sua postura e justificar suas atitudes. Ela expressa uma obseção por destacar-se através de marcas superficiais como o modo de vestir e hábitos peculiares. Essas marcas são denominadas pelo personagem como "estilo":

Olga estaba convencida que el estilo no era solo el barrio y la casa en que vivía, los muebles y chucherías que decoraban, el coche que tenía tu marido, o la ropa que vestías, como pensaban sus amigas; y seguramente por eso, minimizar Madrid formaba también parte de lo llamaba $<<$ mi estilo $>>$, un rasgo complejo que ella enunciaba así: <<Él estilo es tu personalidad,algo que va más allá de las cosas que tienes y usas: es, digámoslo de esa manera,una especie de jersey, de malla, de pijama invisible que te envuelve y que tejes tú misma, con palabras, con gestos, con cosas que tú tienes, o que 
a ti te gustan y que a los demás no se les ocurrían ni buscar; o que incluso dan de lado y hasta desprecian.>> Leyó esa idea muchos años antes, en un libro para señoritas escrito por una inglesa, Shelding, Sheldom, o algo por el estilo, se llamaba aquella mujer (CHIRBES, 2000, p.38).

A fixação de Olga pelo estilo é um modo de fugir da realidade, sua veneração pelas verduras e por Paris são um modo de esconder a violência sexual que ali sofrera: "Se dio cuenta que el sexo y la cultura nada tenían que ver, lo que le creó una desconfianza hasta los hombres que vagamente se extendió también hasta la cultura:" (CHIRBES, 2000, p.260) ${ }^{23}$. A educação voltada para o gênero feminino era diferenciada, como se nota no distanciamento com que ela se relaciona com a política, pois encarava as discussões entre os filhos como uma questão de estilo. Por isso, não se importava com as discussões entre Quini, Tomás e Josemari.

Cuando Quini, a los quince años, pronunció una frase calcada de la que ella había tomado prestada de la escritora inglesa - <<Mamá, cada uno tiene su estilo, y el estilo es lo que te gusta, pero también la manera que tienes de hacer las cosas >>-, intuyó que cada época engendra sus estilos (sus amigas del Opus Dei coleccionaban búhos), y que quizá el estilo de los nuevos tiempos fuera la pasión política; ése era el pijama en que Quini se envolvía para diferenciarse de sus amigos (CHIRBES, 2000, p.38).

No romance a cultura de massa atinge especialmente o público feminino, pois utiliza o amor romântico como temática para esconder uma Espanha devastada e representá-la como um lugar bom. O repertório cultural de personagens como Elvira e Carmen atua como instrumento de manipulação social ao construir uma perspectiva distorcida da realidade. A repressão não se refletia apenas na violência física, estava presente em todos os âmbitos. Desse modo, a cultura tornou-se um mecanismo de dominação do regime, assim como a polícia era mecanismo de controle social que visava a força.

\footnotetext{
${ }^{23}$ Essa questão é abordada por Rafael Chirbes no livro Por cuenta propia. Leer y escribir (2010), pois ele utiliza o relato do narrador e dos personagens para despertar a desconfiança sobre a cultura: "He sometido las coordenadas de mi educación sentimental al juego de espejos de narradores poco fiables, para alertarme a mí mismo - y al lector- acerca de la necesidad de saber moverse entre la seducción de los lenguajes; he fomentado la desconfianza de eso que parece flotar por encima de todas las cosas y que conocemos como cultura: $<<\mathrm{La}$ buena letra es el disfraz de las mentiras >>, dice Ana, la protagonista de La buena letra; "(CHIRBES, 2010, p.33).
} 


\section{Considerações Finais}

A obra apresenta um universo de múltiplos discursos construído por diversos tipos de personagens que revisitam o passado e expõem indagações sobre o presente. A análise da narrativa, sobretudo, das técnicas de representação da consciência, da perspectiva múltipla e da mobilidade do narrador revelam que o romance em questão é de uma riqueza poética notável que conduz o leitor ao interior da psique humana, bem como lhe permite rever a história da Espanha.

No romance, o narrador exerce uma função mediadora na construção da memória, pois revela parcelas dos pensamentos, desejos e anseios de três gerações como peças de um quebra-cabeça que se encaixam aos poucos. A partir das imagens que José, Tomás e Quini elaboram da própria família e de si é possível observar de diversas perspectivas o funcionamento da sociedade no âmbito privado durante o franquismo. As relações familiares refletiam a história da Espanha e o contexto da ditadura militar, pois a censura e o silenciamento eram impostos nesses ambientes também. $\mathrm{O}$ confronto de vozes entre as três gerações sugere que todos foram e continuarão sendo vítimas diretas ou indiretas da Guerra Civil e da ditadura. A análise dos relatos também revela a influência que o franquismo exercia no âmbito civil, como na economia, na cultural e na vida familiar, principalmente em relação às mulheres. Sendo assim, somente os leitores acessam a totalidade, mas eles precisam buscar suas próprias reflexões, trilhando seu próprio caminho na recuperação da memória e da história da Espanha.

Através do confronto de relatos La caída de Madrid propõe uma reflexão sobre a divisão da sociedade espanhola entre vencidos e vencedores e recria a memória social da época, pois num contexto de silêncio, repressão e medo todos estão derrotados de algum modo. Portanto, o romance se contrapõe a ideia de vencedores e vencidos, esta vertente fica evidente quando os vencedores começam a questionar suas identidades, revelando seus medos e fragilidades. O delegado Arroyo teme o final do regime, pois sabe que perderá sua autoridade; José Ricart teme pela continuidade da empresa, pois não confia no filho e pensa em Taboada como uma possibilidade de enfrentar as incertezas do futuro; Guillermo sente-se acuado com a ordem de matar Enrique, pois teme que um dia poderá ser assassinado, como fez com Enrique. 
A complexidade da obra torna-a universal e permite uma reflexão sobre o contexto de todos os regimes totalitários, bem como suas consequências. Transitar entre esses âmbitos apresentados pela narrativa permite compreender como a barbárie implantou-se na sociedade, passando pela vida pública e privada, pelas atividades econômicas até os costumes cotidianos. Diante da análise, conclui-se que mesmo os "silêncios" e "omissões" do âmbito íntimo são também devastadores para a história coletiva. Portanto, retomar a repressão e o tempo silenciado e esquecido é essencial do ponto de vista moral, político e psicológico. Rememorar a ditadura é um movimento necessário para tomar consciência do custo social dos regimes totalitários e, sobretudo, para não repetirmos uma experiência tão desastrosa que custou sangue, exílio e sofrimento. 


\section{REFERÊNCIAS}

ADORNO, T. Posição do narrador no romance contemporâneo. In: Os Pensadores - Textos escolhidos. Trad. José Lino Grunnewald. São Paulo: Abril Cultural, 1983.

ALVES, I. G. La sección feminina de la falange e assistência na Espanha do Primeiro Franquismo. Hispanista, vol.16, p.01-10, 2015. Disponível em: <https://www.aacademica.org/ismael.goncalves.alves/3.pdf> .Acesso em: 17 mar. 2017.

ARISTÓTELES (1992). Arte Poética. Trad. E. de Souza. São Paulo: Arte Poética. (Original publicado em torno de 330 a.C.)

ASMANN, A. Espaços da recordação - Formas e transformações da memória cultural. Trad. Paulo Soethe. Campinas: Editora Unicamp, 2011.

AUB, M. La gallina ciega: diario español. Edición,estudio introductório y notas de Manuel Aznar Soler. Barcelona: Alba Editorial, 1995.

AUERBACH, E. Mimesis. A representação do realismo na literatura ocidental. Trad. Editorial Perspectiva. São Paulo, Perspectiva, 1971.

BARTHES, R. O efeito do real. In: Literatura e Semiologia (Novas Perspectivas em

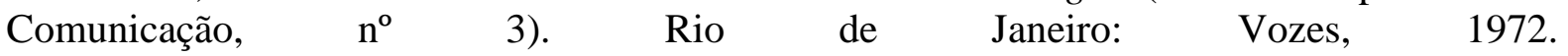

BENJAMIN, W. O narrador. Considerações sobre a obra de Nikolai Leskov. In: Obras Escolhidas. Magia e Técnica, Arte e Política. Trad. Sergio Paulo Rouanet. São Paulo: Brasiliense, 1995, pp. 197-221;

BIESCAS, J. A. La economía española durante el período franquista. Revista Gerónimo de Uztariz, n.3, p. 65-76. Disponível em: http://amarauna.org/uztariz/pdf/artikuluak/aldizkaria0306.pdf. Acesso em: 28 maio 2017.

BONET, C. El Realismo Literario. Buenos Aires, Editorial Nova, 1998.

BOOTH, W. C. A retórica da ficção. Trad. Maria Teresa H. Guerreiro. Editora Arcaria: Lisboa, 1980. 
CASAS, J. M.; URQUIJO, P. C. El exílio español (1936-1978). Barcelona: Editorial Planeta, 2002.

CASTÁN, J. et al. (Orgs.). La memoria de los olvidados - Un debate sobre el silencio franquista. Valladolid: Ámbito, 2004.

CHIRBES, R. Mimoun. Barcelona: Anagrama, 1988.

. En la lucha final. Barcelona: Anagrama, 1991

La buena letra. Barcelona: Anagrama, 1992.

La larga marcha. Barcelona: Anagrama, 1996.

Los disparos del cazador. Barcelona: Anagrama, 1994.

La caída de Madrid. Barcelona: Anagrama, 2000.

. El novelista perplejo. Anagrama: Barcelona, 2002.

. Los viejos amigos. Barcelona: Anagrama, 2003.

. Crematorio. Barcelona: Anagrama, 2007

. Por cuenta propia-Leer y escribir. Barcelona: Anagrama, 2010.

En la orilla. Barcelona: Anagrama, 2013.

París-Austerlitz. Barcelona: Anagrama, 2016.

CHKLÓVSKI, V. A arte como procedimento. In: As estruturas narrativas. TODOROV, T.(org.). Trad. Leyla Perrone-Moisés. São Paulo: Perspectiva, 2008.

A construção da novela e do romance. In: As estruturas narrativas.TODOROV, T. (org.). Trad. Leyla Perrone-Moisés. São Paulo: Perspectiva, 2008. 
CINTRA, L.; CUNHA, C. Nova gramática do português contemporâneo. 6.ed. Rio de Janeiro: Lexicon, 2013.

COLMENERO, S. S. Traición y memoria. Los disparos del cazador. Turia Revista Cultural, Teruel, n. 112, p. 244-250, 2015.

DE MARCO, V. A literatura de testemunho e a violência de estado. Lua nova, n.62, 2004. Disponível em: http://www.scielo.br/pdf/ln/n62/a04n62. Acesso em: 12 abr. 2015.

\begin{tabular}{llll}
\multicolumn{2}{c}{ Romance, mulher e política na Espanha de pós-guerra. Anuario brasileño de estudios } \\
hispânicos, & v.10, & Disponível
\end{tabular} $<$ https://sede.educacion.gob.es/publiventa/descarga.action?f_codigo_agc=16789>. Acesso em: 17 mar. 2017.

DELGADO, J. L. G. Estacamiento industrial e intervencionismo econômico durante el primer franquismo. In: España bajo el franquismo. FONTANA, J. (org.). Barcelona: Editorial Crítica, 1986.

EHRLICH, M. I. Memoria y revolución: el desengaño de una quimera. In: Ensayos sobre Rafael Chirbes. EHRLICH, M. T. I. (org.). Iberoamericana: Madrid, 2006.

ELLWOOD, S. M. Falange y franquismo. In: España bajo el franquismo. FONTANA, J. (org). Crítica: Barcelona, 1986.

ESPINOSA, D. F. A. Cristianos y marxistas contra Franco. Cádiz: Universidad, Servicio de Publicaciones, 2003.

FONTANA, J. (Org.). España bajo el franquismo. Barcelona: Editorial Crítica, 1986.

FOUCAULT, M. Avida dos homens infames. In: Estratégia, poder-saber. Ditos e escritos IV. Trad. Vera Lucia Avellar Ribeiro. Rio de Janeiro: Forense Universitária, 2006. p.203-222.

.O que é um autor? Ditos e escritos: Estética - literatura e pintura, música e cinema. Trad. Inês Autran Dourado Barbosa. vol.3. Rio de Janeiro: Forense Universitária, 2006. p. 264-298. 
FUSI, J. P. Historia Mínima de España. México, DF: El colegio de México, Madrid: Turner, 2012.

HALBWACHS, M. A memória coletiva. Trad. Beatriz Sidou. São Paulo: Centauro, 2009.

HERAS, M. O; MARTÍNEZ. C. G. Control social y control policial en la dictadura franquista. Historia del presente. v.9, p.27-47, 2007. Disponível em: <https://dialnet.unirioja.es/servlet/articulo?codigo=3001729>. Acesso em: 03 maio 2017.

HIERRO, M. Ficción de la memoria en La larga marcha y La caída de Madrid, de Rafael Chirbes. Turia Revista Cultural, Teruel, n. 112, p. 235- 243, 2015.

HUMPHREY, R. La corriente de la conciencia en la novela moderna. Editorial Universitaria, 1969.

JACOBS, H. C. Entrevista con Rafael Chirbes. Iberoamericana, $3 / 4$ (75/76), p.175-181, 1999.

Las novelas de Rafael Chirbes. Iberoamericana, 3/4 (75/76), p.182-187, 1999.

LARISCH, C. G. ;Manda narices! El paisaje olfativo de En la orilla, de Rafael Chirbes.2013. 32 f. Bachelor Degree (Lenaguages and Literatures - Spanish Studies), Universitet Lunds, 2013. Disponível em: <http://lup.lub.lu.se/student-papers/record/4255215>. Acesso em: 23 abr 2015.

LEÓN, E. G. El miedo, legado generacional en los personajes de Chirbes. In: Ensayos sobre Rafael Chirbes. EHRLICH, M. T. I. (org.). Iberoamericana: Madrid, 2006.

LEUENBERGER, D. Acercamiento a la obra narrativa de Rafael Chirbes: Los disparos del cazador. In: Revista Consensus, Lima, v.10, p.1-14, 2015. Disponível em: $<\mathrm{http}$ ///www.unife.edu.pe/publicaciones/revistas/consensus/volumen10.html >. Acesso em: 14 abr 2015.

LIKHATCHOV, D. Sobre el realismo y su definición. Trad. Desiderio Navarro. In: Textos e Contextos. Havana, Arte y Literatura, 1985. 
MALGAT, G. Las obras testimoniales de Max Aub sobre la guerra de Espanã: las difíciles memorias de la derrota y del exilio. Revista Amnis, 2011. Disponível em: $<$ http://amnis.revues.org/1514>. Acesso em: 17 de abr de 2015.

MARTIN GAITE, C. Desde la ventana: enfoque femenino de la literatura española. Espasa Calpe: Madrid, 1988.

MENDILOW, A. Tempo e o Romance. Trad. Flávio Wolf. Porto Alegre: 1972.

OLIVER, M. G. El movimiento estudantil español durante el Franquismo (1965-1975). Revista Crítica de Ciências Sociales, Centro de Estudos Sociales da Universidade de Coimbra, n.81, p.93-110, 2008. Disponível em: <http://rccs.revues.org/652>. Acesso em: 07 fev. 2017.

POLLAK, M. Memória, esquecimento, silêncio. Trad. Dora Rocha Flaksman. v.3, n.3, p.315.Estudos Históricos, Rio de Janeiro, 1989.

RICOEUR, P. A memória, a história, o esquecimento. Trad. Alain Fraçois. Campinas: Editora da Unicamp, 2007. 2003.

.La memoria, la historia, el olvido. Trad. Agustín Neira. Madrid: Editorial Trotta, ficção. São Paulo: Perspectiva, 1995.

SCHMITZ, S. La caída de Madrid, una novela histórica de Rafael Chirbes o el arte nuevo de cometer un deicidio real(ista) en el siglo XXI. In: Ensayos sobre Rafael Chirbes. EHRLICH, M. T. I. (org.). Iberoamericana: Madrid, 2006.

SALVADÓ, F. J. R. A guerra civil espanhola. Trad. Barbara Duarte. Rio de Janeiro: Jorge Zahar Ed, 2008.

SALVADOR, P.; SILVA, E. (Orgs.). La memoria de los olvidados - Un debate sobre el silencio franquista. Valladolid: Ámbito, 2004.

SANTOS, L. M. Tiempo de Silencio. Barcelona: Seix Barral, 1993. 
STRATER, T. Intermidialidade no romance español contemporáneo La larga marcha, de Rafael Chirbes. Aletria: Revista de Estudos de Literatura,v. 19, n. 2, jan/jun, 2009. Disponível em: <http://dx.doi.org/10.17851/2317-2096.19.2.181-191> Acesso em: 08/ abr/2015.

TELLEZ, A. M. A educação na ditadura: A educação espanhola no período franquista 19391959. Cadernos de História da Educação, v.15, n.1, p.443-452, 2016. Disponível em: <http://dx.doi.org/10.14393/che-v15n1-2016-18>. Acesso em: 21 mar. 2017.

VALLS, F. La narrativa de Rafael Chirbes: entre las sombras de la historia. Turia Revista Cultural, Teruel, n. 112, p. 127-145, 2015.

TOMACHEVSKI, B. A temática. In: As estruturas narrativas. TODOROV, T. (org.). Trad.Leyla Perrone-Moisés. São Paulo: Perspectiva, 2008.

VILAR, P. La historia de España. Barcelona: Grijalbo, 1980. 
A: ESFERAS DE REPRESSÃO

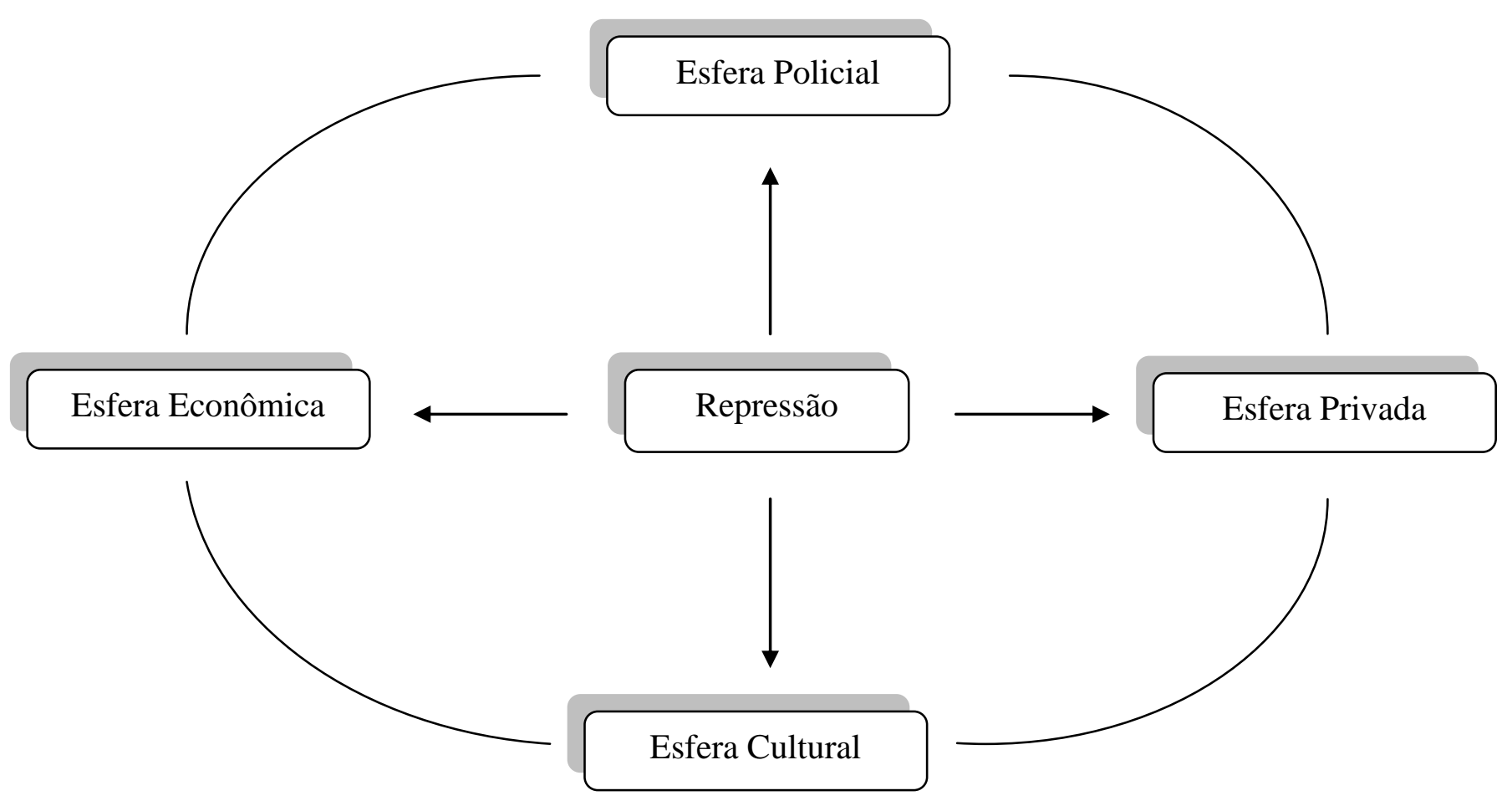




\section{B: NÚCLEOS DE PERSONAGENS}

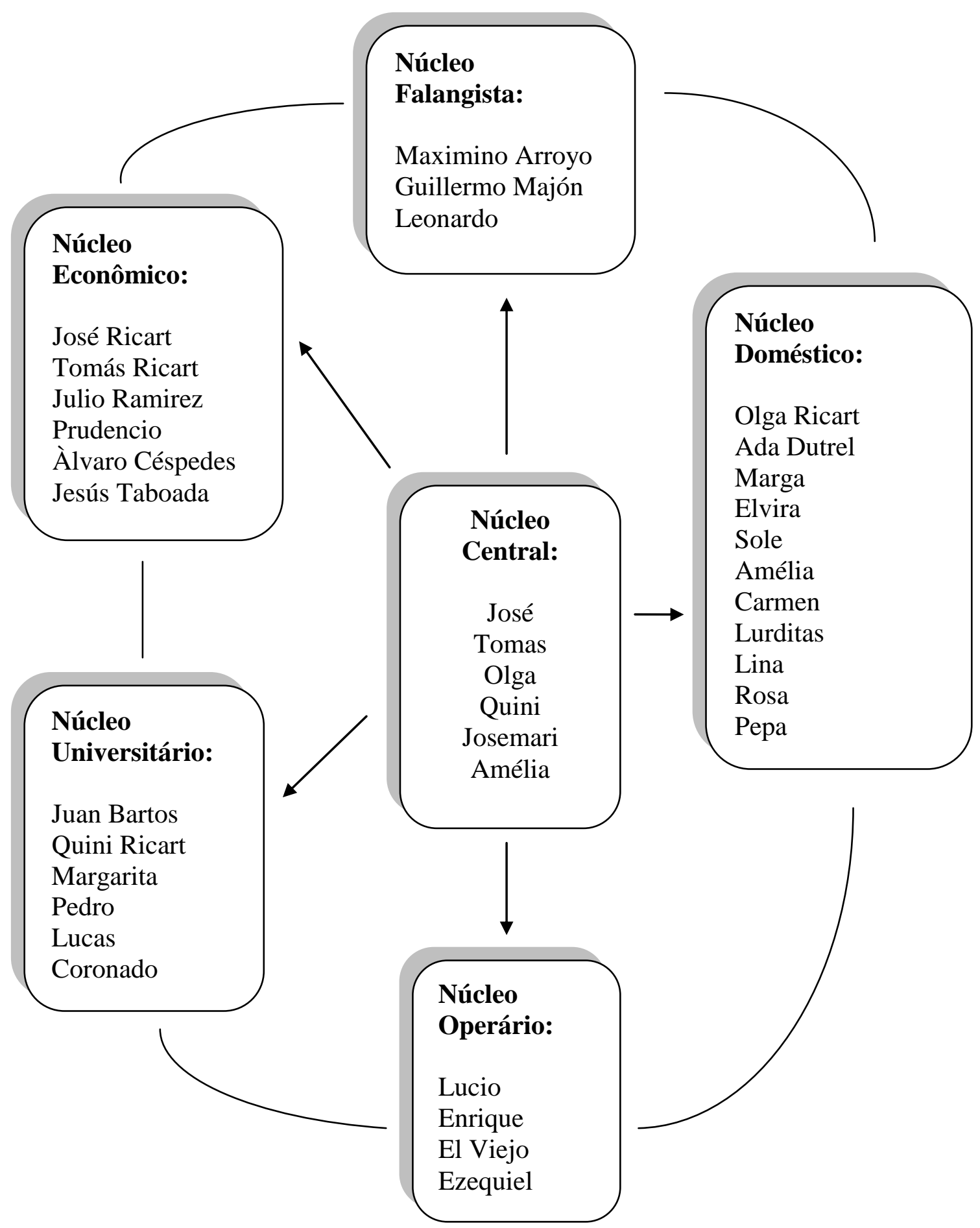


C: ESFERA POLICIAL E OPERÁRIA

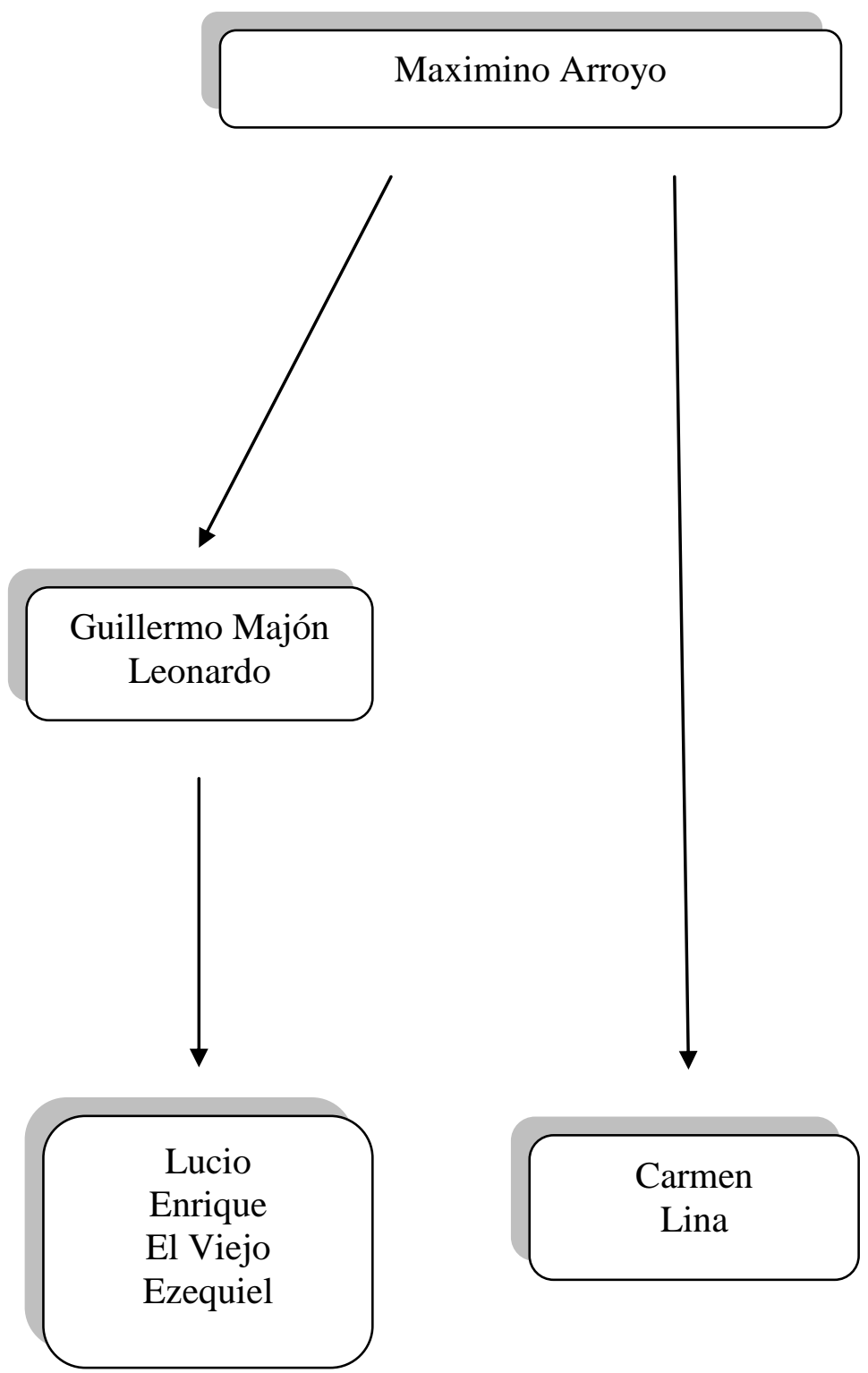




\section{D: ESFERA PRIVADA}

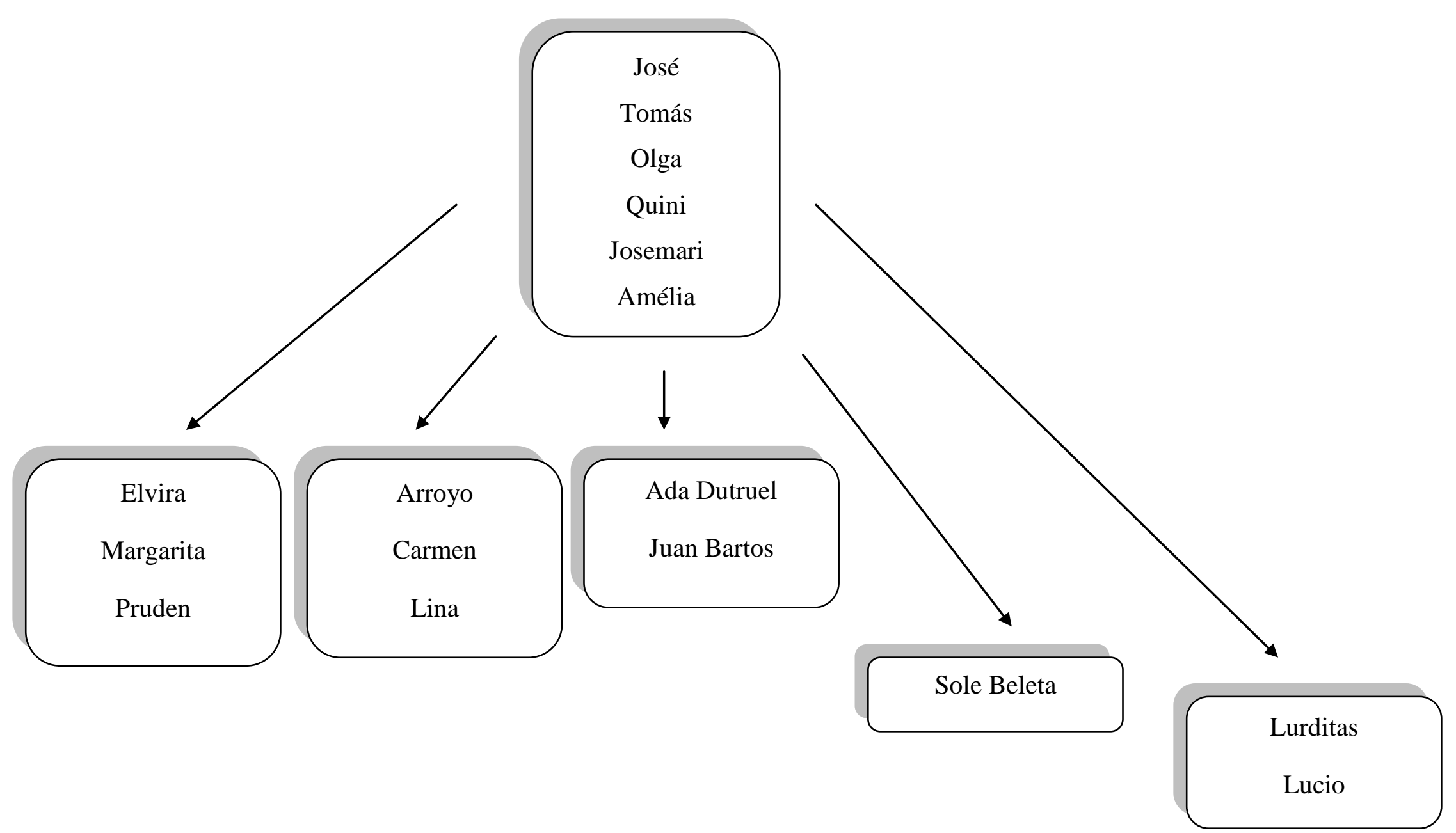




\section{E: ESFERA ECONÔMICA}

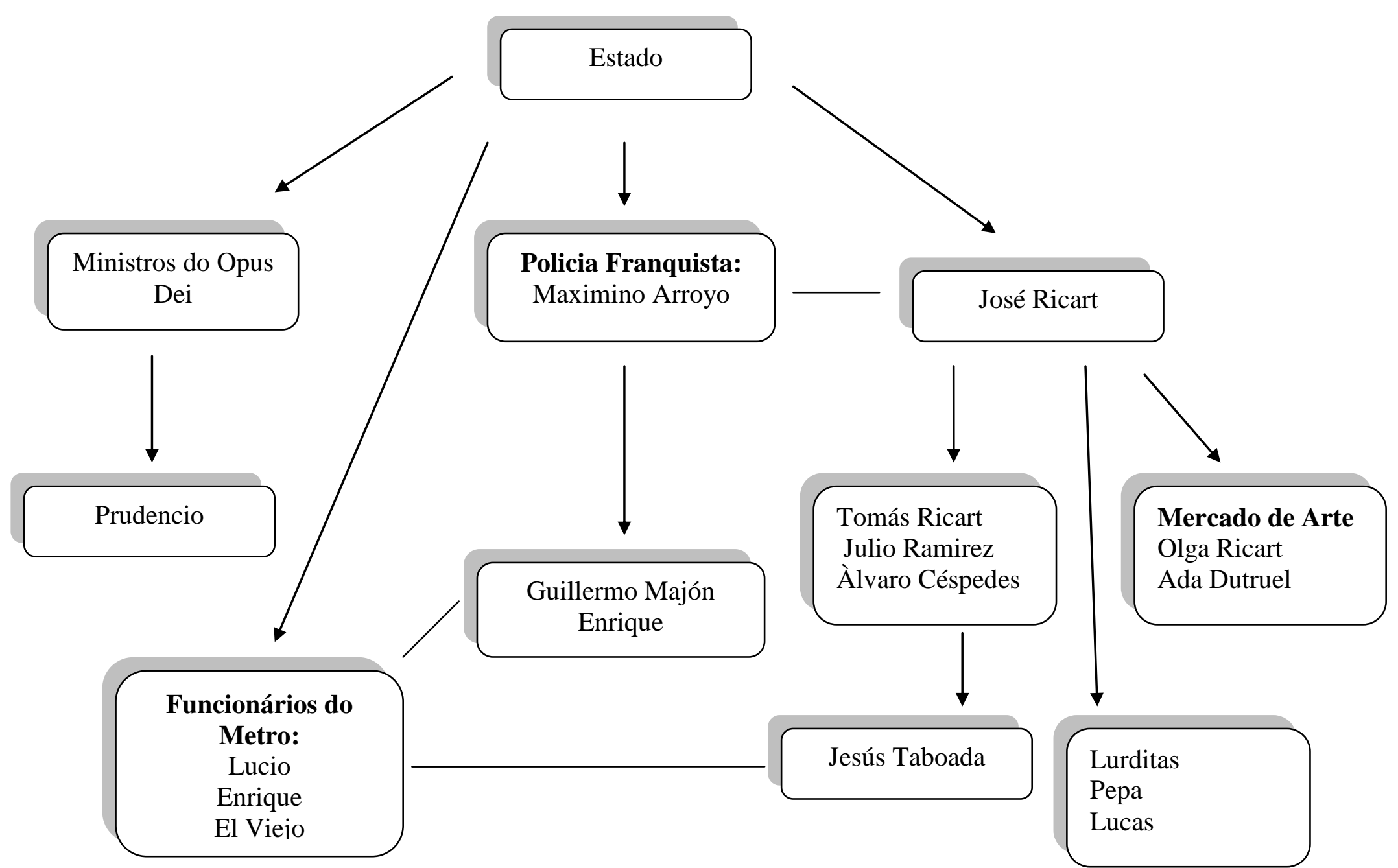


F: ESFERA CULTURAL

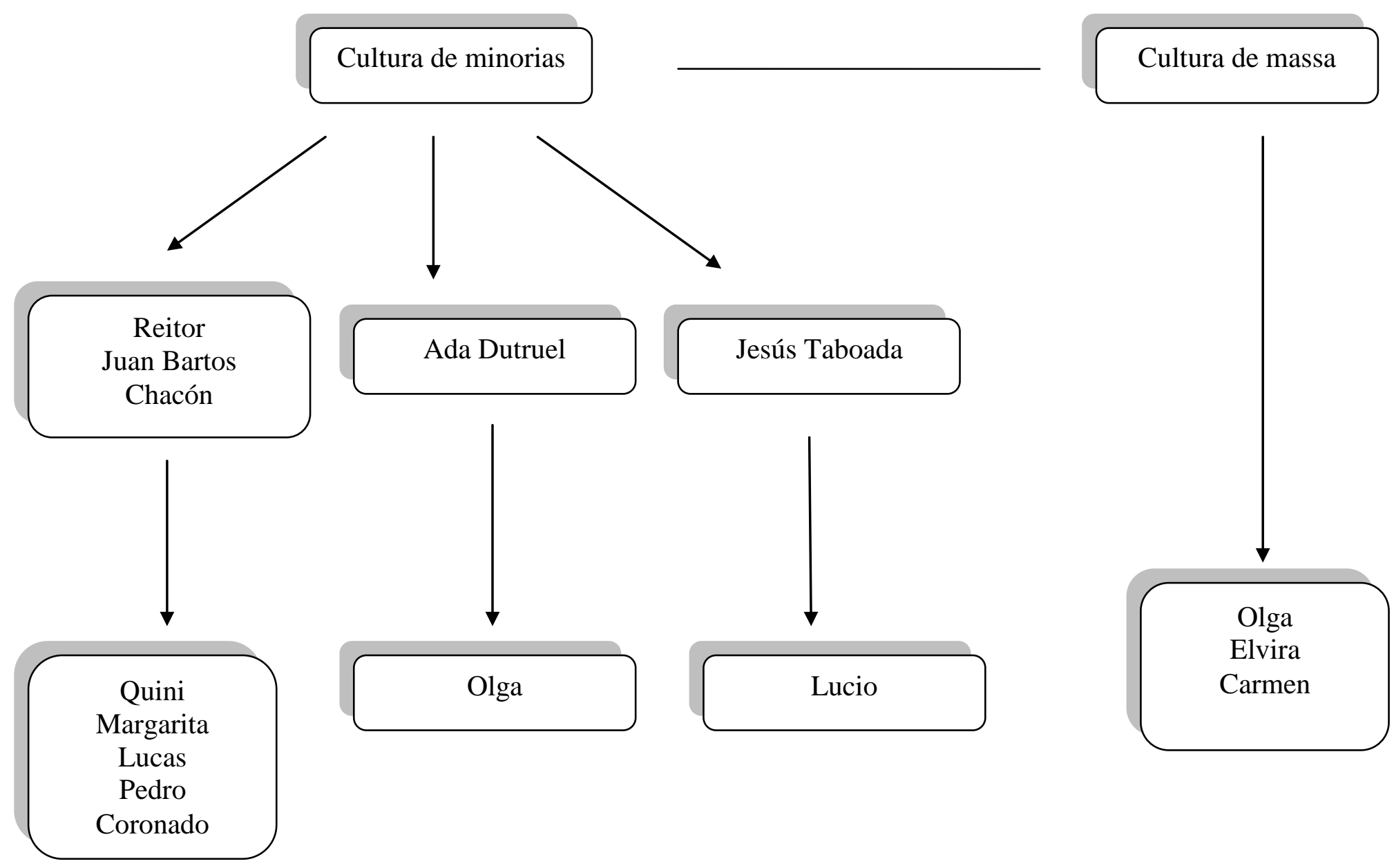

